\title{
A critical appraisal of appendage disparity and homology in fishes
}

\author{
Olivier Larouche $^{1}$ (D) | Miriam L. Zelditch ${ }^{2}$ | Richard Cloutier ${ }^{1}$
}

\author{
${ }^{1}$ Laboratoire de Paléontologie et de Biologie \\ évolutive, Université du Québec à Rimouski, \\ Rimouski, QC, Canada \\ ${ }^{2}$ Museum of Paleontology, University of \\ Michigan, Ann Arbor, MI, USA \\ Correspondence \\ Olivier Larouche, Department of Biological \\ Sciences, Clemson University, Clemson, SC \\ 29631, USA. \\ Email: olarouc@g.clemson.edu

\section{Funding information} \\ Fonds de Recherche Nature et Technologies \\ Québec, Grant/Award Number: B1; Natural \\ Sciences and Engineering Research Council \\ of Canada, Grant/Award Number: BESC-M, \\ 238612 and PGS-D
}

\begin{abstract}
Fishes are both extremely diverse and morphologically disparate. Part of this disparity can be observed in the numerous possible fin configurations that may differ in terms of the number of fins as well as fin shapes, sizes and relative positions on the body. Here, we thoroughly review the major patterns of disparity in fin configurations for each major group of fishes and discuss how median and paired fin homologies have been interpreted over time. When taking into account the entire span of fish diversity, including both extant and fossil taxa, the disparity in fin morphologies greatly complicates inferring homologies for individual fins. Given the phylogenetic scope of this review, structural and topological criteria appear to be the most useful indicators of fin identity. We further suggest that it may be advantageous to consider some of these fin homologies as nested within the larger framework of homologous fin-forming morphogenetic fields. We also discuss scenarios of appendage evolution and suggest that modularity may have played a key role in appendage disparification. Fin modules re-expressed within the boundaries of fin-forming fields could explain how some fins may have evolved numerous times independently in separate lineages (e.g., adipose fin), or how new fins may have evolved over time (e.g., anterior and posterior dorsal fins, pectoral and pelvic fins). We favour an evolutionary scenario whereby median appendages appeared from a unique field of competence first positioned throughout the dorsal and ventral midlines, which was then redeployed laterally leading to paired appendages.
\end{abstract}

\section{KEYWORDS}

appendage evolution, fin-forming fields, homology, median and paired fins, modularity, morphological disparity

\section{1 | INTRODUCTION}

Homology is a fundamental concept in biological sciences (Hall, 1994a). Homologous characters are quintessential for phylogenetic analyses, while also providing traits that can be used to identify taxa for taxonomists, and traits that can be compared among clades for evolutionary biologists. However, there is a lack of consensus among biologists as to the criteria that should be used to establish homology (e.g., similarity through topographical correspondence and/or ontogenetic transformation, congruence or anatomical singularity, shared developmental processes, common evolutionary origins; Hall, 1994b; Patterson, 1982, 1988). All this considered, identifying homologies of morphological traits across large phylogenetic scales is not always straightforward, as many structures are likely to have accrued changes in morphology and function over evolutionary time.

Fish appendages represent one such case where homologies have historically been difficult to interpret. Among the factors that complicate inferring fin homologies are that fishes are both extremely 
diverse (ranging from $\sim 32,000$ to $~ 35,000$ valid species according to current estimates [Fricke, Eschmeyer, \& Fong, 2018; Nelson, Grande, $\&$ Wilson, 2016]) and morphologically disparate. One aspect of this disparity concerns the numerous possible fin configurations differing in the number of fins, fin shapes and sizes, fin positions on the body and types of skeletal support (Larouche, Zelditch, \& Cloutier, 2017). Additionally, fishes also have a rich fossil record. This is particularly relevant for the jawless fishes, or agnathans, as it is largely within this paraphyletic group that median and paired fins sequentially appeared. Extant agnathans comprise only hagfishes (Myxiniformes) and lampreys (Petromyzontiformes), neither of which can be considered as exhibiting primitive morphologies: both groups possess combinations of some apomorphic traits and others that have been transformed or lost from the ancestral condition (Furlong \& Holland, 2002; Ota, Fujimoto, Oisi, \& Kuratani, 2011, 2013; Shimeld \& Donoghue, 2012). Hagfishes and lampreys have well-developed median fins but lack paired fins. Fin configurations are much more diversified in fossil jawless fishes, some of which also have paired appendages (Larouche et al., 2017). However, the quality and completeness of preservation for fossilized agnathans is variable, which complicates interpretations of homologies for their appendages. Yet another aspect that complicates interpreting fin homologies is that in some taxa, median and paired fins have diverged and/or been coopted towards a number of specialized functions. Examples include fins modified as sensory organs (e.g., adipose fins in salmonids), as suctorial apparatuses used to cling to hard surfaces or to other organisms (e.g., lumpsuckers, clingfishes, remoras and some gobies), and as lures used to attract prey (e.g., anglerfishes).

Fins are functionally important for locomotion, yet they are also evolutionarily labile structures that can generate high levels of morphological disparity, notably among ray-finned fishes (Larouche, Zelditch, \& Cloutier, 2018). The morphological and functional disparity of fish appendages, the quality of the fossil record and the paraphyly of fishes all complicate inferring homologies of fins. With this in mind, our main objective is to review the major patterns of fin configuration disparity throughout the phylogeny of fishes and discuss how fin homologies have historically been interpreted. We begin by demonstrating that a clear definition even of what constitutes a fin is difficult to find in the scientific literature and propose a set of defining characteristics for the term. We then provide an exhaustive review of fin-like structures in all major clades of both jawless (agnathans) and jawed fishes (gnathostomes) and discuss proposed homologies for these appendages across the different groups. To our knowledge, this is the first thorough review of disparity and suggested homologies for both the median and paired fins performed with such a large macroevolutionary scope.

\section{2 | THE INHERENT COMPLEXITIES OF SIMPLY DEFINING THE TERM 'FIN'}

In this section, we begin by providing a historical account of how median and paired fin identities have been interpreted by previous

\begin{tabular}{|l|l|}
\hline 1. INTRODUCTION & \\
\hline 2. THE INHERENT COMPLEXITIES OF SIMPLY & 1138 \\
\hline DEFINING THE TERM 'FIN' & 1139 \\
\hline 3. APPENDAGE DISPARITY IN CHORDATES & 1141 \\
\hline 3.1 Non-vertebrate chordates & 1142 \\
\hline 3.2 Stem vertebrates & 1144 \\
\hline 3.3 Myxiniformes & 1144 \\
\hline 3.4 Petromyzontiformes & 1145 \\
\hline 3.5 Conodonta & 1146 \\
\hline 3.6 Anaspida & 1146 \\
\hline 3.7 Pteraspidomorphi & 1147 \\
\hline 3.8 'Thelodonti' & 1148 \\
\hline 3.9 'Cephalaspidomorphi' & 1148 \\
\hline 3.10 'Placodermi' & 1150 \\
\hline 3.11 'Acanthodii' & 1150 \\
\hline 3.12 Chondrichthyes & 1151 \\
\hline 3.13 Actinopterygii & 1152 \\
\hline 3.14 Sarcopterygii & 1154 \\
\hline 4. DISCUSSION & 1155 \\
\hline 5.CONCLUSION & 1158 \\
\hline ACKNOWLEDGEMENTS & 1158 \\
\hline CONFLICT OF INTEREST & 1158 \\
\hline DATA AVAILABILITY STATEMENT & 1158 \\
\hline REFERENCES & 1158 \\
\hline & \\
\hline
\end{tabular}

authors. In doing so, we wish to emphasize the array of arguments that have been used to discuss fin homologies, including structural, topological, functional and developmental considerations. We conclude this section by summarizing the set of criteria that we find most informative in defining fins and their identities.

It may be surprising to find that a clear definition of what constitutes a 'fin' is uncommon (even inexistent) in recent literature. Perhaps this can be attributed to the morphological and functional diversity of these appendages, precluding an all-encompassing definition of the term. Nonetheless, for centuries, it has been recognized that a common character of fishes is that they generally have fins (Table 1). For example, although Aristotle did not clearly define 'fins', he observed that these were essentially organs of locomotion and that fishes displayed much disparity in their fin configurations (Aristotle \& Barthélémy-Saint-Hilaire, 1883; Aristotle, Cresswell, \& Schneider, 1878). Antoine Goüan defined 'fins' as parts composed of a series of rays or spines, covered and united by a membrane, that project from the body and are used to accomplish all of the different movements necessary for swimming; he further distinguished what he considered were 'true fins' from appendages that he designated as 'false fins', the latter being simple folds of skin without spines or rays (Goüan, 1770). Bernard Germain de Lacépède used a similar definition while adding that some fishes possess membranes without rays 
TAB LE 1 Summary of how fins have been 'defined' historically

\begin{tabular}{|c|c|c|c|}
\hline $\begin{array}{l}\text { Years of } \\
\text { birth-death }\end{array}$ & Author & Homology criteria & Elements of the definitions \\
\hline $384-322 \mathrm{BC}$ & Aristotle & Functional & $\begin{array}{l}\text { Fins are organs of locomotion and differences in fin configurations relate to differ- } \\
\text { ences in swimming style. }\end{array}$ \\
\hline 1507-1566 & $\begin{array}{l}\text { Guillaume } \\
\text { Rondelet }\end{array}$ & Functional & $\begin{array}{l}\text { Fins are functionally important to fish as are wings to birds; fins differ widely among } \\
\text { species in their shapes, sizes, colours, positions and structures. However, Rondelet } \\
\text { classifies all aquatic animals as fishes (e.g., sea turtles, marine mammals, crusta- } \\
\text { ceans, molluscs). }\end{array}$ \\
\hline 1517-1564 & Pierre Belon & Functional & $\begin{array}{l}\text { Belon also compares fins to bird wings and classifies aquatic animals such as dol- } \\
\text { phins and hippopotami as fishes. }\end{array}$ \\
\hline $1733-1821$ & Antoine Goüan & $\begin{array}{l}\text { Structural, } \\
\text { functional and } \\
\text { topological }\end{array}$ & $\begin{array}{l}\text { True fins are composed of rays or spines united by a membrane. Fins are function- } \\
\text { ally used either as oars or rudders. Goüan distinguishes fins based on their position } \\
\text { on the body; he also developed an elaborate descriptive terminology for each of } \\
\text { the median and paired fins taking into account their position, size, shape, structure } \\
\text { and number. }\end{array}$ \\
\hline 1769-1832 & Georges Cuvier & $\begin{array}{l}\text { Structural, } \\
\text { functional and } \\
\text { topological }\end{array}$ & $\begin{array}{l}\text { Pectoral fins correspond to the limbs of other vertebrates. Median fins can be } \\
\text { identified based on their position and are used as keels or rudders of a boat. Cuvier } \\
\text { also describes the internal skeletal structures of the median and paired fins. }\end{array}$ \\
\hline 1804-1892 & Richard Owen & $\begin{array}{l}\text { Structural, } \\
\text { functional and } \\
\text { topological }\end{array}$ & $\begin{array}{l}\text { The paired fins are homologous to the limbs of other vertebrates; both are sup- } \\
\text { ported by inverted arches, respectively, the scapular and pelvic arches. The } \\
\text { pectoral fins are involved in raising and depressing the body during locomotion, } \\
\text { the pelvic fins prevent rolling, the caudal fin acts as a propeller, and the anal fin } \\
\text { acts as a keel. }\end{array}$ \\
\hline $1825-1895$ & $\begin{array}{l}\text { Thomas Henry } \\
\text { Huxley }\end{array}$ & $\begin{array}{l}\text { Structural and } \\
\text { topological }\end{array}$ & $\begin{array}{l}\text { The paired fins are homologous to the limbs of other vertebrates, although the ele- } \\
\text { ments of the internal skeleton only imperfectly correspond to those of tetrapods. } \\
\text { Median and paired fins can be recognized based on their position. }\end{array}$ \\
\hline
\end{tabular}

Note: See text for references.

or rays without membranes and that these should nonetheless be termed fins owing to their position and/or function (Lacépède, 1798; Lacépède, Cuvier, \& Desmarest, 1853).

Notwithstanding the difficulties of defining 'fins' in general, fish appendages can be further separated into two categories: median (or unpaired) and paired fins. Despite their opposing views on many topics, both Owen (1854) and Huxley (1871) considered that, from a morphological and structural standpoint, median fins consist of skin folds that are supported by dermal bones termed rays or spines. However, these authors interpreted the low median folds of integument present in the dorsal and caudal regions of cephalochordates as homologous to the median fin system of other fishes despite the absence of rays or spines. Goodrich (1909, p. 71) described the median fins as 'longitudinal median structures, internally segmented like the body itself, and involving many segments'. The preceding definitions of median fins focused on morphological or anatomical criteria, but other authors instead provided functional definitions of the median fins comparing them to the keels or rudders of boats (Cuvier,
1849; Cuvier \& Valenciennes, 1828; Lacépède, 1798; Lacépède et al., 1853).

Median fins can further be categorized by their position on the body. Dorsal fins are located on the dorsal midline between the head and the tail, the anal fins are located along the ventral midline between the anus (or cloaca) and the tail, and the caudal fin is located at the extremity of the tail (Goüan, 1770; Günther, 1880; Huxley, 1871; Lacépède, 1798; Lacépède et al., 1853). Some taxa bear additional fins along the midline. Dorsally, a number of actinopterygians have an adipose fin. Günther (1880) used the term 'fatty fin' and defined it as a dorsal rayless fold of skin in which fat is deposited. More recently, the adipose fin has been described as a small non-rayed fin usually located medially between the dorsal and caudal fins and variably present among several groups of basal euteleosts (Reimchen $\&$ Temple, 2004). Although the fin-rays are generally absent, the adipose fin-web is nonetheless supported by proximodistally oriented rods of collagen, termed actinotrichia (Stewart \& Hale, 2013; Stewart, Smith, \& Coates, 2014). Two additional forms of dermal 
skeleton can be found in the adipose fin of some Siluriformes and Characiformes: anterior spines derived from modified scutes and true fin-rays (Stewart, 2015; Stewart et al., 2014). In some euteleosts, a ventral adipose fin is also described (Fischer \& Bianchi, 1984; Greenwood, Rosen, Weitzman, \& Myers, 1966). Furthermore, in some agnathans, a median ventral fin-fold can be found, positioned anteriorly to the cloaca and of variable extent.

Paired fins have a lateral rather than a median insertion along the body. In gnathostomes, the paired fins comprise the pectoral and pelvic fins. As with the median fins, some authors have used topological criteria to distinguish both sets of paired fins: the pectoral fins are located closely behind the gill openings, whereas the pelvic or ventral fins, even though they display more disparity in their position, are inserted on the abdomen and always anteriorly to the anus (Cuvier, 1849; Cuvier \& Duméril, 1835; Cuvier \& Valenciennes, 1828; Goüan, 1770; Günther, 1880). Paired fins have also been defined in the light of their homology with the fore- and hindlimbs of tetrapods (Cuvier, 1849; Cuvier \& Duméril, 1835; Cuvier \& Valenciennes, 1828; Günther, 1880; Huxley, 1871; Owen, 1846, 1849, 1854). Owen (1849) considered that both the anterior and posterior members are structures supported by inverted arches: the pectoral fins are supported by the scapular arch (i.e., pectoral girdle) and the pelvic fins by the pelvic arch (i.e., pelvic girdle). Owen's definitions of pectoral and pelvic appendages are thus strongly based on the nature of the appendicular skeleton and its relative positioning, even though he acknowledged that the position is frequently variable (Owen, 1854). Huxley $(1871$, p. 2) did not define the paired fins per se but stated that vertebrate paired limbs 'are always provided with an internal skeleton, to which the muscles moving the limbs are attached'. Reflecting Owen and Huxley's definitions of paired limbs, numerous recent authors consider that to qualify as homologs of pectoral or pelvic fins, paired fins must be inserted on an endoskeletal girdle and they must be supported by a series of endoskeletal (basals and radials) and exoskeletal (fin-rays) elements (Janvier, 1996a; Wilson, Hanke, \& Märss, 2007). Johanson (2010) added that, at least in gnathostomes, the paired fins are generally narrow-based and their movement is under muscular control. Other authors have emphasized functional considerations to define the paired fins. For example, Belon (1551) and Rondelet (1558) characterized the pectoral and pelvic fins as 'wings' that fishes use to 'fly' through the water. Howell (1933) suggested that the pectoral fins were owing to a requirement of voluntary movement for progression, whereas the pelvic fins evolved mainly for involuntary static action for support or balance.

Although so far we have only mentioned pectoral and pelvic fins, some taxa, among them many fossil agnathans, possess paired appendages that do not strictly conform to the definitions of pectoral and pelvic fins provided above. These appendages, which can be found in some anaspids and thelodonts, have variously been described using terms such as (ventro)lateral fins or fin-folds (e.g., Blom, 2008; Blom, Märss, \& Miller, 2002; Ritchie, 1964; Ritchie, 1968a, 1980), paired anteroventral fins (Chevrinais et al., 2018), pectoral swimming appendages (Stensiö, 1964), paired or pectoral flaps (e.g., Dineley \& Loeffler, 1976; Donoghue \& Smith, 2001; Märss, Turner,
\& Karatajūtē-Talimaa, 2007; Turner, 1982, 1991) and suprabranchial fins (e.g., Johanson, 2010; Wilson et al., 2007).

For the purpose of this review, and to account for the structural and functional disparity in fin configurations, we propose a few defining characteristics of fins that can be applied across both extant and extinct taxa. Fins are (a) anatomical structures that project externally from the body outline (b) and that are generally composed of a membrane supported by endo- and exoskeletal elements, although either of these can be absent. Thus, as did Lacépède (Lacépède, 1798; Lacépède et al., 1853), we consider that fin-folds without endoskeletal support or serial rays or spines without webbing should also be considered as fins. However, ridges that form along angular regions of the body and that contain neither membranes nor skeletal supports do not qualify as fins. As for the identity of the fins, we emphasize the utility of positional criteria: dorsal fins are located on the dorsal side, anal fins are on the ventral side between the anus and the tail, and the caudal fin is at the extremity of the tail. Some species present additional unpaired fin-folds that can be inserted either anteriorly (e.g., some Myxiniformes) or posteriorly to the cloaca (e.g., some Paralepididae): these will be termed 'median ventral (or preanal) fins'. As for the paired appendages, we will consider that pectoral fins are inserted on the thorax close to the gill openings, pelvic fins are ventrally inserted anteriorly to the cloaca, and both fins must have narrow bases. Other paired structures, either in the form of long ribbon-like folds or serially repeated fin supports, will be termed 'ventrolateral paired fins'.

\section{3 | APPENDAGE DISPARITY IN CHORDATES}

In this section, we review which appendages are present/absent across the phylogeny from basal chordates to piscine sarcopterygians (Figure 1). For every major group of fishes, we highlight which fins contribute most to the patterns of disparity in appendage configurations and we discuss suggested homologies. Our characterization of fin configurations focuses on adult morphologies, and thus, fin-folds that are only present during the early stages of development are not taken into consideration. Throughout this section, we refer to some groups as 'basal' or 'advanced', and as 'stem' or 'crown'. Wherever applicable, we have prioritized the use of 'stem' and 'crown' groups, as defined by Jefferies (1979) based on the conceptual framework from Hennig (1969). More precisely, a crown group is a clade, nested within a larger 'total group', that includes all extant representatives of that total group. The stem group refers to the paraphyletic assemblage of exclusively fossil taxa that are part of the total group but basal to the crown group. For extant taxa, we will use 'basal' when referring to those taxa that are closer to the stem and that display plesiomorphic character combinations for their respective crown group (sensu Trueb \& Cloutier, 1991). Accordingly, by 'advanced' we are referring to the taxa that are further from the stem and exhibit derived 
characteristics of the crown group. Because phylogenetic relationships among some of these groups remain unresolved and that this can have a bearing on how homologies are interpreted, we also call attention to the hypotheses of interrelationships that have been proposed.

\section{1 | Non-vertebrate chordates}

Chordates comprise three subphyla: Cephalochordata, Tunicata and Craniata (including Vertebrata). Based on shared morphological characters, the cephalochordates have long been considered as the sister group to craniates (e.g., Garstang, 1928; Herdman, 1904; Maisey, 1986; Rowe, 2004; Schaeffer, 1987; Shimeld \& Holland, 2000). However, an alternative hypothesis has also been proposed whereby tunicates, and not cephalochordates, are the sister group to craniates (Jefferies, 1973, 1979, 1986; Jefferies \& Lewis, 1978), a view that is well supported by many recent molecular-based phylogenetic analyses (e.g., Blair \& Hedges, 2005; Bourlat et al., 2006; Delsuc, Brinkmann, Chourrout, \& Philippe, 2006; Delsuc, Tsagkogeorga, Lartillot, \& Philippe, 2008; Dunn et al., 2008; Heimberg, CowperSallari, Semon, Donoghue, \& Peterson, 2010; Philippe, Lartillot, \& Brinkmann, 2005; Putnam et al., 2008; Singh et al., 2009).

The extant representatives of the Cephalochordata are the Amphioxiformes, or lancelets, which include between 30 and 35 species divided into two genera (Hubbs, 1922; Poss \& Boschung, 1996; Satoh, Rokhsar, \& Nishikawa, 2014; Stokes \& Holland, 1998). Lancelets possess a fin-fold along the dorsal and ventral midlines of the body that is continuous around the tip of the tail, as well as along the anterior tip of the notochord, where it forms a 'rostral fin' (Andrews, 1893; Bigelow \& Farfante, 1948; Goodrich, 1930; Herdman, 1904; Holland \& Holland, 1991; Jefferies, 1986; Jordan \& Evermann, 1896; Jordan \& Gilbert, 1882; Jordan \& Snyder, 1901; Kirkaldy, 1895; Lankester, 1889; Rice, 1880; Wiley, 1894). Schaeffer (1987) suggested the median fin-fold of lancelets to be homologous with the larval median fin-fold of developing vertebrates. Some authors describe the posteroventral part of the median finfold as an anal fin (e.g., Goodsir, 1844; Jordan \& Evermann, 1896; Jordan \& Snyder, 1901) despite the fact that its anterior insertion is in front of the anus, while others use the term preanal fin (e.g., Hubbs, 1922; Xu, Ma, \& Wang, 2005). Rod-like structures along the dorsal and ventral fins have sometimes been interpreted as fin-rays (e.g., Andrews, 1893; Bigelow \& Farfante, 1948; Goodrich, 1930; Jefferies, 1986; Lankester, 1889; Wiley, 1894; Yarrell, 1836). It is now clear that these so-called fin-rays of lancelets are not homologous to the radials or dermal rays of vertebrates (Holland \& Chen, 2001; Holland \& Holland, 1991). They are in fact retroperitoneal accumulations of haemal fluid containing nutritional reserves that project into coeloms along the median fin-folds; they shrink and disappear during gametogenesis or if the individuals are subjected to starvation (Azariah, 1965; Holland \& Holland, 1991; Stokes, 1996). Paired structures, termed metapleural folds, arise posteriorly to the oral hood, extending ventrolaterally under the branchial region and atrial cavity (Andrews, 1893; Goodrich, 1930; Goodsir, 1844;
Herdman, 1904; Jefferies, 1986; Kirkaldy, 1895; Lankester, 1875, 1889; Rice, 1880; Wiley, 1894). Posteriorly, the left metapleural fold is continuous with the median ventral fin in Epigonichthys, whereas both metapleural folds are interrupted behind the atriopore in Branchiostoma (Kirkaldy, 1895; Poss \& Boschung, 1996). Thacher (1877) suggested that the metapleural folds were homologous to the continuous lateral fin-folds from which pectoral and pelvic fins are hypothesized to have evolved. However, these are hollow structures that are filled with fluid and they become flattened and inconspicuous during the spawning season when the atrial cavity is distended owing to the increasing space occupied by the developing gonads (Lankester, 1875, 1889; Rice, 1880; Wiley, 1894). Therefore, metapleural folds are neither structured, nor are they functionally used as fins in cephalochordates (Wiley, 1894).

Tunicates, or urochordates, comprise three classes and about 3,000 species (Satoh et al., 2014; Shenkar \& Swalla, 2011). As adults, they are sac-like marine filter-feeding organisms, yet a post-anal tail and fin-fold is present during the larval stage in two of the classes, the Ascidiacea and Thaliacea, and persists during the entire life cycle in representatives of the third class, the Appendicularia (Cloney, 1982; Herdman, 1904; Nishino \& Satoh, 2001). The tail includes the notochordal axis, muscle fibres, as well as dorsal and ventral finfolds that are continuous around the posterior tip of the notochord (Berrill, 1930; Cloney, 1982; Herdman, 1904; Kowalevsky, 1866; McHenry, 2005). Tunicates are hypothesized to have arisen during or even before the Cambrian diversification; however, their fossil record is very poor owing to the absence of mineralized parts and the only undisputed fossil tunicate is from the Lower Cambrian of China (Chen et al., 2003).

The fossil record also contains a few forms that have variously been interpreted as stem deuterostomes, cephalochordates, stem chordates or stem craniates (i.e., Yunnanozoon lividum, Haikouella lanceolata, $\mathrm{H}$. jianshanensis, Pikaia gracilens, Cathaymyrus diadexus). Yunnanozoon, from the Lower Cambrian of southern China, was originally interpreted as a worm-like animal bearing a segmented cuticle (Hou, Ramskold, \& Bergstrom, 1991). Although some authors have suggested cephalochordate affinity (e.g., Chen, Dzik, Edgecombe, Ramsköld, \& Zhou, 1995; Stokes \& Holland, 1998), it seems more likely that Yunnanozoon is a stem deuterostome that is nested neither in craniates or vertebrates (e.g., Bergström, Naumann, Viehweg, \& Martí- Mus, 1998; Shu, 2003, 2008; Shu, Morris, Zhang, \& Han, 2010). Dorsal and ventral dark bands extending along the midline (Chen et al., 1995; Dzik, 1995) have been interpreted as dorsal and ventral fin-folds (Chen et al., 1995). Shu, Zhang, and Chen (1996) interpreted the existence of a much larger sclerotized and segmented dorsal fin, a view which has been disputed based on recent evidence from the closely allied Haikouella suggesting that the segments are actually myomeres (Mallatt \& Chen, 2003; Mallatt, Chen, \& Holland, 2003). Paired ventrolateral folds are observable on many specimens (Chen \& Li, 1997; Dzik, 1995) and have been compared to the metapleural folds of cephalochordates (Chen \& Li, 1997). Based on the morphology of Haikouella, Y. lividum has occasionally been reconstructed as having a caudal process bearing a fin-web (e.g., Chen 
FIGURE 1 Simplified phylogeny of fishes showing the distribution of median and paired fins. The topology summarizes the results of the supertree analysis in Larouche, Zelditch, and Cloutier (2017). The presence of median and paired fins in at least some members of each taxonomic group is represented by the boxes with dark and light grey outlines, respectively. The filled boxes represent the presence of median and paired fins that can confidently be homologized to those of gnathostomes

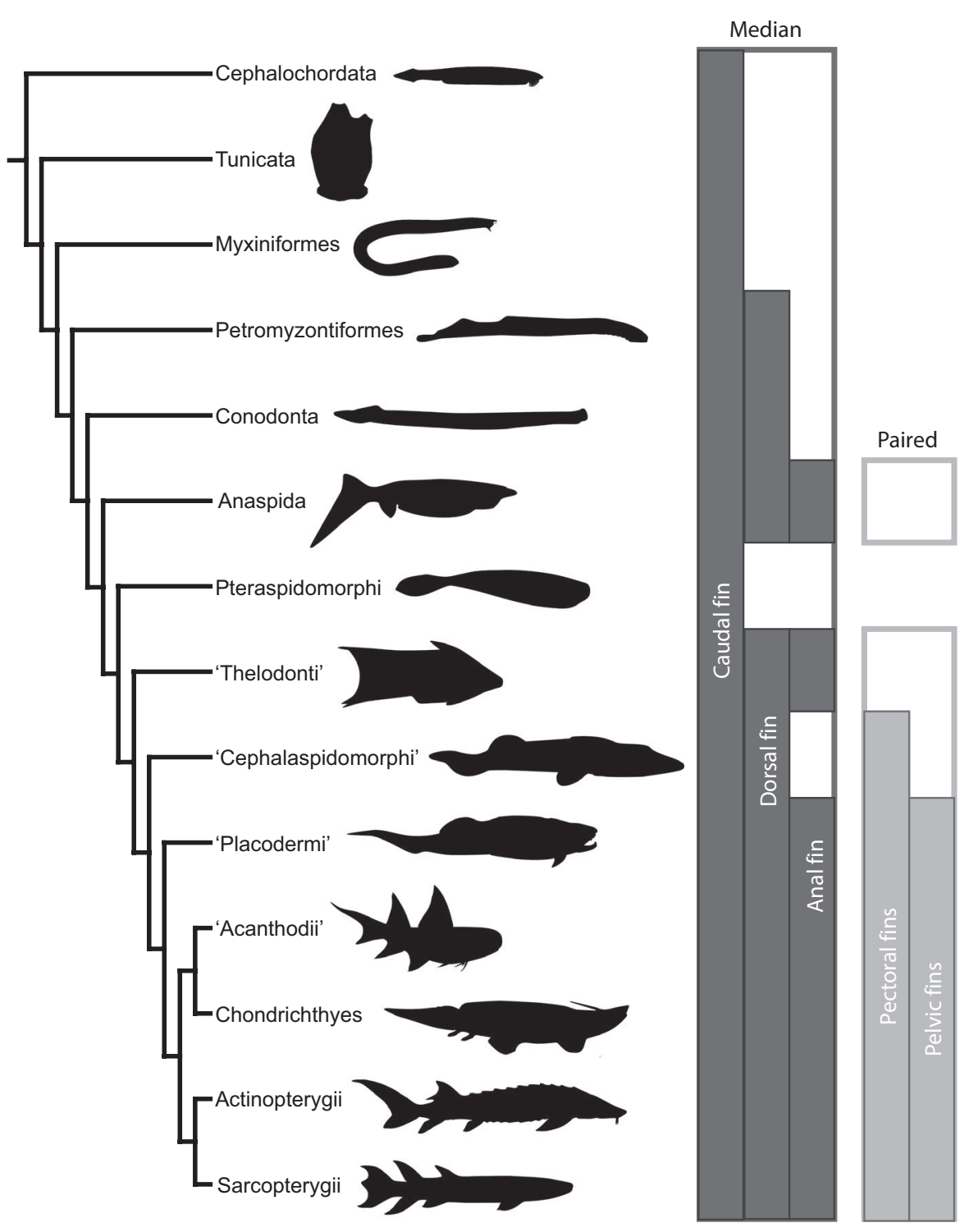

\& Huang, 2006; Chen \& Huang, 2008). However, Chen and Huang (2008) acknowledge that this structure has not been observed in any of the Yunnanozoon specimens.

Haikouella is known from hundreds of complete specimens from the Lower Cambrian of southern China (Chen, Huang, \& Li, 1999). Some specimens of Haikouella present a post-anal tail (referred to as a 'caudal process') posteriorly to the anus; its absence in other individuals is thought to be a result of breaking off during fossilization (Chen et al., 1999; Mallatt \& Chen, 2003). An alternate view is that the caudal process is a taphonomic artefact brought about by folding and compaction of the posterior part of the body (Shu \& Morris, 2003). Medially, there are also dorsal and ventral fins but lateral appendages are entirely absent (Holland \& Chen, 2001). The fins in Haikouella do not contain rays (Mallatt \& Chen, 2003). Similarly to Yunnanozoon, the phylogenetic position of Haikouella is debated. On the one hand, this taxon might be a stem deuterostome (Shu, 2003, 2008; Shu \& Morris, 2003; Shu et al., 2010; Shu, Morris, Zhang, et al., 2003). Alternatively, it might be a stem craniate if the interpretation of structures identified as a brain, eyes, a post-anal tail and median fins are correct (Chen et al., 1999; Mallatt \& Chen, 2003; Mallatt et al., 2003). Some phylogenetic analyses have resolved Haikouella at the base of craniates (Holland \& Chen, 2001; Mallatt \& Chen, 2003), suggesting that yunnanozoans (i.e., Yunnanozoon + Haikouella) may be the sister group of all other craniates. Based on a more recent investigation of over 700 specimens, Cong, Hou, Aldridge, Purnell, and Li (2015) argued that yunnanozoan characters can be open to alternative interpretations and that their affinities to other groups should conservatively be considered within a wider bilaterian context. Notwithstanding the uncertain phylogenetic position of yunnanozoans, it is generally agreed that Yunnanozoon and Haikouella are either close relatives (Mallatt \& Chen, 2003; Mallatt et al., 2003; Shu \& Morris, 2003; Shu, Morris, Zhang, et al., 2003) or even possibly synonyms (Cong, Hou, Aldridge, Purnell, \& Li, 2015; Turner et al., 2010).

Pikaia, from the Middle Cambrian Burgess Shale of western Canada, was originally interpreted as a polychaete owing to 
the presence of curious lateral appendages in the branchial area (Walcott, 1911, 1931). Subsequent investigations of the material revealed chordate-like characters (Insom, Pucci, \& Simonetta, 1995; Morris, 1979; Morris \& Whittington, 1979), and Pikaia has since been interpreted as closely related to cephalochordates (e.g., Shu et al., 1999; Smith, Sansom, \& Cochrane, 2001; Stokes \& Holland, 1998) or to yunnanozoans (Morris \& Caron, 2012). Following a thorough re-examination of the Pikaia material, the only appendages described are a dorsal fin-fold without fin-rays and a series of nine bilaterally arranged appendages with possible pharyngeal pores near their insertions (Morris \& Caron, 2012). There is also a ventral keel extending from just behind the last of the lateral appendages and becoming less distinct posteriorly which might have represented a median ventral fin, or possibly a gonadal structure (Morris \& Caron, 2012). Mallatt and Holland (2013, p. 268) argued that the ventral keel and posterior ventral area are most definitively a fin because they 'look fin-like and seem to be homologues of a fin'. Although a tail-fin devoid of fin-rays has been mentioned in some descriptions (Briggs \& Kear, 1994; Insom et al., 1995; Smith et al., 2001), this feature is absent in Morris and Caron (2012)'s detailed revision of the material.

Cathaymyrus was originally described based on a single specimen from the Lower Cambrian of southern China (Shu, Morris, \& Zhang, 1996). Cathaymyrus has been interpreted as lacking any evidence for fins or fin-rays (Shu, Morris, et al., 1996; Smith et al., 2001), although a dorsal fin is explicitly mentioned in Shu (2003). It has been suggested that Cathaymyrus might actually be a crushed specimen of Yunnanozoon; however, this hypothesis was later discredited (Luo, Hu, \& Chen, 2001; Shu, Chen, Zhang, Han, \& Li, 2001; Shu et al., 2010). Cathaymyrus is generally interpreted as belonging to cephalochordates (Mallatt \& Holland, 2013; Morris, 2006; Shu, 2008; Stokes $\&$ Holland, 1998).

\subsection{Stem vertebrates}

Four Cambrian representatives of stem vertebrates (Zhongjianichthys rostratus, Myllokunmingia fengjiaoa, Haikouichthys ercaicunensis and Metaspriggina walcotti) are sufficiently well known to permit discussion of their fin configurations. Common to all four species is the absence of paired fins. Median ventral and dorsal fins are present in Zhongjianichthys (Shu, 2003), Myllokunmingia (Holland \& Chen, 2001; Shu, 2008; Shu et al., 1999; Hou, Aldridge, Siveter, \& Feng, 2002) and Haikouichthys (Holland \& Chen, 2001; Shu, 2008; Shu et al., 1999; Shu, Morris, Han, et al., 2003; Hou et al., 2002; Zhang $\&$ Hou, 2004). In the original descriptions of Myllokunmingia and Haikouichthys, doubts were expressed concerning the interpretation of a ventral structure that could have been either a median ventral fin-fold or paired ventrolateral fin-folds (Shu et al., 2001, 1999). Subsequent discoveries and analyses of additional specimens of Haikouichthys provided no indications whatsoever that the ventral fin-fold is a paired structure (Shu, 2008; Shu, Morris, Han, et al., 2003; Hou et al., 2002; Zhang \& Hou, 2004). A dorsal fin was originally considered to be absent in Metaspriggina (Simonetta \& Insom,
1993). Later, a narrow area along the anterior trunk of the lectotype was interpreted as a possible dorsal fold or ridge (Morris, 2008). The most recent revision of the Metaspriggina material suggests that it was entirely finless although a keel-like structure is present along the ventral midline; Morris and Caron (2014) mentioned however that the absence of fins could be a taphonomic artefact. With the exception of Zhongjianichthys where the presence of an anal fin cannot be determined, a distinct anal fin is absent in all of these stem vertebrates. A caudal fin is present in Haikouichthys and absent in Metaspriggina; its presence cannot be assessed for Zhongjianichthys and Myllokunmingia.

Myllokunmingia, Haikouichthys and Zhongjianichthys are considered as close relatives and have been assigned to the order Myllokunmingiida (Shu, 2003). They are either interpreted as stem craniates (Shu, 2003; Shu, Morris, Han, et al., 2003) or stem vertebrates (Shu, 2005; Shu et al., 2001). It has been suggested that Myllokunmingia and Haikouichthys might be synonyms (e.g., Blieck, 2011; Janvier, 2007; Turner et al., 2010; Hou et al., 2002; Žigaitè \& Blieck, 2013), while other authors consider that these taxa are correctly identified as separate species (Morris, 2006; Morris \& Caron, 2012; Shimeld \& Holland, 2000). Zhongjianichthys has also been proposed as a possible synonym and badly preserved specimen of Myllokunmingia (Blieck, 2011; Janvier, 2007; Žigaitè \& Blieck, 2013) or Haikouichthys (Morris \& Caron, 2012). Recently, Morris and Caron (2014) supported Metaspriggina's vertebrate affinity based on the presence of a notochord, camerular eyes, paired nasal sacs, a possible cranium, possible arcualia, $\mathrm{W}$-shaped myomeres and a post-anal tail.

\section{3 | Myxiniformes}

Myxines, or hagfishes, are either the most basal of extant craniates or they are basal vertebrates (see next subsection for hypothesized interrelationships among hagfishes, lampreys and gnathostomes) and comprise a single order, with about 79 extant species (Zintzen et al., 2015). Their fossil record extends at least to the Upper Carboniferous (but possibly as far as the Middle Devonian if Palaeospondylus gunni is confirmed as a primitive hagfish as suggested by Hirasawa, Oisi, \& Kuratani, 2016) and includes five extinct species, three of which are only tentatively assigned to the Myxiniformes (Bardack, 1991, 1998; Bardack \& Richardson, 1977; Germain, Sanchez, Janvier, \& Tafforeau, 2014; Hirasawa et al., 2016; Miyashita et al., 2019; Poplin, Sotty, \& Janvier, 2001). Hagfishes have a simple fin configuration that comprises a caudal fin supported by cartilaginous fin-rays (Adam \& Strahan, 1963; Ota, Fujimoto, Oisi, \& Kuratani, 2011, 2013; Wright, Keeley, \& DeMont, 1998) and a median preanal fin-fold (Fernholm, 1998). The caudal fin can be absent in some extant species. For instance in Myxine formosana, the caudal fin is described as vestigial or absent (McMillan \& Wisner, 2004; Mok \& Kuo, 2001). Hagfishes generally lack a distinct dorsal fin, although in the Carboniferous Myxinikela siroka, a dorsal fin arises somewhat anterior to the mid-body and is continuous with the caudal fin posteriorly (Bardack, 1991, 1998). However, Bardack (1991, 
1998) mentioned that the specimen might represent a juvenile stage of development.

The preanal fin-fold of hagfishes is devoid of skeletal supports (Hardisty, 1979) and is in fact a band of thin fleshy tissue found along the ventral midline starting from the cloaca and differing among species in its anterior extent (Wisner \& McMillan, 1995). The preanal fin-fold is reported absent in the extant Myxine debueni (Fernholm, 1998; Wisner \& McMillan, 1995) as well as in the Carboniferous Gilpichthys greenei, a fossil species that lacks all types of fins including the caudal fin (Bardack \& Richardson, 1977). It should be mentioned that Gilpichthys is known from a single specimen and its assignment to Myxiniformes has been debated: it might in fact constitute an immature organism (Bardack, 1998; Bardack \& Richardson, 1977). However, a recent phylogenetic analysis reaffirmed its position as a stem hagfish (McCoy et al., 2016). The presence and conspicuity of the preanal fin-fold can also vary intraspecifically; in some species, it is reported either as weakly developed, vestigial or absent (e.g., Kuo, Huang, \& Mok, 1994; McMillan \& Wisner, 2004; Wisner \& McMillan, 1988, 1990).

Paired fins are generally considered as entirely absent in Myxiniformes although both species of Neomyxine present lateral folds of skin located immediately above the gill openings (Richardson, 1953, 1958; Zintzen et al., 2015). Contrary to the paired fins found in most other craniates, these 'ventrolateral branchial fin-folds' are located dorsally to the branchial openings and do not seem to be used in swimming but rather as support when individuals settle on substrate (Adam \& Strahan, 1963; Janvier, 1978; Richardson, 1953). Furthermore, there are no traces of internal skeletal support or of an associated specialized musculature (Forey, 1984). Because Neomyxine is not resolved as the most basal taxon among Myxiniformes (Zintzen et al., 2015), this structure is unlikely to be homologous to the paired fins of other vertebrates (Donoghue, Forey, \& Aldridge, 2000).

\section{4 | Petromyzontiformes}

Petromyzontiformes, or lampreys, also comprise a single order including 43 extant and five fossil species (Chang, Wu, Miao, \& Zhang, 2014; Hume, Bean, \& Adams, 2014; Renaud, 2011). The oldest fossil lamprey is Priscomyzon riniensis from the Upper Devonian of South Africa (Gess, Coates, \& Rubidge, 2006). The caudal fin is always present in extant lampreys, with the exception of a single specimen of Lampetra planeri that was described as having an incompletely formed caudal fin (Hume et al., 2014). Among fossil lampreys, the caudal fin is absent only in Pipiscius zangerli (Bardack \& Richardson, 1977). However, the affinity of Pipiscius to the petromyzontids has been questioned (Bardack, 1998; Janvier \& Lund, 1983). Recent phylogenetic analyses have resolved this taxon's position either as a stem lamprey (McCoy et al., 2016; Sallan et al., 2017) or as a stem cyclostome (Miyashita et al., 2019). Furthermore, a yolk sac might be present, suggesting that Pipiscius could represent a larval organism (Bardack \& Richardson, 1977).

Most extant lampreys have two dorsal fins, with the exception of all species belonging to Ichthyomyzon that have a single dorsal fin (Renaud, 2011). As for fossil lampreys, most species have a single dorsal fin (Bardack \& Zangerl, 1968; Chang et al., 2014; Chang, Zhang, \& Miao, 2006; Gess et al., 2006; McCoy et al., 2016), excepting Hardistiella montanensis that has two dorsal fins (Janvier \& Lund, 1983; Janvier, Lund, \& Grogan, 2004). A median preanal finfold, such as was described for hagfishes, is absent in lampreys. In extant species, an anal fin with skeletal support is typically absent although two specimens of Petromyzon marinus have been found with an anal fin with cartilaginous fin-rays, a condition interpreted as an atavism (Janvier, 1996a, 2007, 2008; Vladykov, 1973; Vladykov $\&$ Kott, 1980). Hume et al. (2014) also reported the presence of an anal fin supported by five or six fin-rays in a single specimen of the extant L. planeri. Additionally, female lampreys preparing to spawn develop fleshy pre- and post-anal fin-like folds (Hardisty \& Potter, 1971; Janvier \& Lund, 1983; Kott, Renaud, \& Vladykov, 1988; Pletcher, 1963; Renaud, 2011; Vladykov, 1973; Vladykov \& Kott, 1980). Similarly, in males and females of Petromyzontidae, the bases of the dorsal fins become swollen prior to reproduction in a way that makes them appear united (Hardisty \& Potter, 1971; Kott et al., 1988; Renaud, 2011). Anal fins have been described in two fossil species, H. montanensis (Janvier \& Lund, 1983) and Mayomyzon pieckoensis (Bardack \& Zangerl, 1968). In Hardistiella, a small notch separates the chordal lobe of the caudal fin from the anal fin (Janvier \& Lund, 1983). Later, Janvier and Arsenault (2007) expressed that the presence of an anal fin required confirmation in this species. As for Mayomyzon, the dorsal, anal and caudal fins are continuous along the body, the latter being separated from the first two by small notches (Bardack \& Zangerl, 1968). Janvier and Lund (1983) questioned the presence of a true anal fin in Mayomyzon and suggested that this might instead be the typical anal fin-like fold found in spawning female lampreys.

Paired fins are entirely lacking in all fossil and extant lampreys. Janvier (1981b) suggested that the absence of paired fins is most likely secondary in the Petromyzontiformes based on their being present in closely related groups (e.g., anaspids). In support of this palaeontological hypothesis, it has been shown that the absence of paired fins in lampreys can be traced back to ventrally migrating extensions of the dermomyotome, effectively separating the lateral plate mesoderm from the overlying ectoderm (Tulenko et al., 2013). In tetrapods, the proper development of many elements of the paired limbs and girdles are known to require signalling between the ectoderm and the lateral plate mesoderm (Capdevila \& Izpesúa Belmonte, 2001; Ehehalt, Wang, Christ, Patel, \& Huang, 2004; Malashichev, Borkhvardt, Christ, \& Scaal, 2005; Malashichev, Christ, \& Prols, 2008; Wang et al., 2005). Tulenko et al. (2013) further suggest that the persistence of somatic lateral plate mesoderm external to the myotomes was a key step towards the development of paired fins in gnathostomes.

A final representative of the Petromyzontiformes requires separate mention owing to its uncharacteristic morphology, Tullimonstrum gregarium. Tullimonstrum, from the Upper Carboniferous of Illinois, USA, was originally described as a worm-like animal (Richardson, 1966), and its relationship to annelids, molluscs or arthropods have been considered (see Turner et al., 2010 for a review of these 
hypothesized relationships). Based on a re-examination of over 1,200 specimens and the inclusion of the reinterpreted characters into a phylogenetic analysis, Tullimonstrum has recently been resolved as a stem lamprey (McCoy et al., 2016). However, Sallan et al. (2017) have raised issues concerning some biological, functional and taphonomical interpretations of the data that were used to establish vertebrate identity, as well as with the use of an all-chordate data set for the phylogenetic analyses. Based on a reanalysis of the character matrix from McCoy et al. (2016) with some characters rescored, Sallan et al. (2017) suggest that a non-vertebrate assignment for Tullimonstrum is more likely. Notwithstanding the uncertainty in its phylogenetic placement among stem lampreys, Tullimonstrum possesses a single long and low dorsal fin, as well as an asymmetrical oblanceolate caudal fin (Clements et al., 2016; McCoy et al., 2016).

The interrelationships among lampreys, hagfishes and gnathostomes have been debated for many years, and two competing hypotheses have been proposed: (1) either lampreys and hagfishes form a clade called the cyclostomes (Duméril, 1806; Schaeffer \& Thomson, 1980; Shimeld \& Donoghue, 2012), (2) or hagfishes are craniates while lampreys are vertebrates, making the 'cyclostomes' paraphyletic relative to the gnathostomes (Dingerkus, 1979; Forey, 1984; Forey \& Janvier, 1993; Hardisty, 1979; Janvier, 1978, 1981b, 1996b; Janvier \& Blieck, 1979; Jefferies, 1986 Løvtrup, 1977). Cyclostome monophyly was initially suggested based on morphological arguments (e.g., Schaeffer \& Thomson, 1980; Yalden, 1985) and is well supported by molecular phylogenetic analyses (Delarbre, Gallut, Barriel, Janvier, \& Gachelin, 2002; Furlong \& Holland, 2002; Hedges, 2001; Heimberg et al., 2010; Mallatt \& Sullivan, 1998; Mallatt, Sullivan, \& Winchell, 2001; Stock $\&$ Whitt, 1992). In contrast, analyses based on morphological data sets and incorporating fossil taxa have generally resolved 'cyclostomes' as paraphyletic relative to gnathostomes (Donoghue et al., 2000; Donoghue \& Smith, 2001; Forey, 1995; Gess et al., 2006; Janvier, 1996a; Khonsari, Li, Vernier, Northcutt, \& Janvier, 2009; Miyashita, 2012; Turner et al., 2010). However, one such recently published phylogenetic analysis incorporating a newly discovered undisputed fossil hagfish has now recovered the cyclostomes as monophyletic (Miyashita et al., 2019). Moreover, Miyashita et al. (2019) found that anaspids and conodonts are resolved as stem cyclostomes using maximum parsimony, whereas anaspids are stem cyclostomes while conodonts are stem hagfishes using Bayesian inference. If this hypothesis gains additional support in future analyses, this would have major implications concerning the evolution of paired fins in jawless fishes. Because anaspids have paired appendages, if they are indeed stem cyclostomes, this would support the hypothesis that the absence of paired fins is owing to secondary loss not only in lampreys (Janvier, 1981b; Tulenko et al., 2013), but also in hagfishes and possibly conodonts.

\section{5 | Conodonta}

The conodont fossil record extends from the Upper Cambrian to the Upper Triassic (Aldridge \& Smith, 1993). Depending on classifications, conodonts comprise between five and seven orders, most of which are known only from remains of the oral apparatus (Aldridge, Purnell, Gabbott, \& Theron, 1995; Aldridge \& Smith, 1993; Dzik, 1991; Sweet, 1988). Although there are close to 5,000 named species, Sweet (1988) estimated that 1,446 species in 246 genera represent a more conservative figure. Only a few species are known from articulated specimens, exceptionally showing preservation of some of the soft tissues anatomy: one of these is Promissum pulchrum, known only from well-preserved material from the anterior portion of the animal (Aldridge \& Theron, 1993; Gabbott, Aldridge, $\&$ Theron, 1995), and two others belong to the genus Clydagnathus (C. windsorensis and Clydagnathus? sp. [C.? sp. cf. C. cavusformis]; Aldridge, Briggs, Clarkson, \& Smith, 1986; Aldridge, Briggs, Smith, Clarkson, \& Clark, 1993; Briggs, Clarkson, \& Aldridge, 1983). In the latter species, the elements of the oral apparatus most useful for identification purposes remain for the most part buried in the sediment: Briggs et al. (1983) tentatively assigned the material to C. cavusformis on the basis of general similarities, while expressing their uncertainty in that respect.

Because there are so few well-preserved specimens with postcranial material preserved, little is known concerning the fin configurations in conodonts. The tail region is preserved in some of the Clydagnathus material and shows a well-developed caudal fin supported by fin-rays (Aldridge et al., 1986, 1993; Aldridge \& Purnell, 1996; Briggs, 1992; Briggs et al., 1983; Pridmore, Barwick, \& Nicoll, 1997). In C. cavusformis, there is a gap in the fin-rays along the dorsal midline, followed anteriorly by a second series that is interpreted as a dorsal fin (Aldridge et al., 1986; Briggs et al., 1983). Indications as to the presence of other median or paired fins have not been found.

The affinity of conodonts is still strongly debated. Until the discovery of some specimens with elements of the soft anatomy preserved (Aldridge, 1987; Aldridge et al., 1986; Briggs et al., 1983; Gabbott et al., 1995), they had been interpreted as belonging to a number of invertebrate and vertebrate groups (see Aldridge et al., 1993 for a review of previously hypothesized conodont interrelationships), or assigned to a separate phylum (Sweet, 1988). Current suggestions include (a) that they are chordates lying outside of craniates/vertebrates (Aldridge, 1987; Aldridge \& Briggs, 1990; Aldridge et al., 1986; Blieck et al., 2010; Pridmore et al., 1997; Turner et al., 2010), (b) that they occupy a basal position among crown vertebrates (Aldridge \& Purnell, 1996; Aldridge \& Theron, 1993; Briggs, 1992; Briggs \& Kear, 1994; Donoghue et al., 2000; Donoghue, Purnell, \& Aldridge, 1998; Gabbott et al., 1995; Purnell, 1995; Schubert, Escriva, Xavier-Neto, \& Laudet, 2006; Sweet \& Donoghue, 2001) or (c) that they are stem cyclostomes (Miyashita et al., 2019).

\section{6 | Anaspida}

The stratigraphic range of the Anaspida extends from the Lower Silurian to the Upper Devonian (Blom et al., 2002; Janvier, 1996b). Anaspids comprise two or three orders depending on classifications and about 25 genera. Some authors consider that true anaspids are only those taxa that possess tri-radiate post-branchial spines: this 
includes the scaled anaspids, or birkeniids, and members of the genus Lasanius (Arsenault \& Janvier, 1991; Blom, 2012; Blom et al., 2002; Janvier, 1996b, 1996c). We favour the more inclusive view whereby the 'naked-anaspids' or Jamoytiiformes, a group that shares with other anaspids the possession of a strongly hypocercal tail, are nested within the Anaspida (Blom \& Märss, 2010; Chevrinais et al., 2018; Keating \& Donoghue, 2016; Kiaer, 1924; Robertson, 1941; Stensiö, 1939; von Zittel \& Woodward, 1902).

Anaspids present some challenges as to the interpretation of their fin configurations. All sufficiently known anaspids possess at least a caudal fin and an anal fin. These fins were supported by radials that were most likely under muscular control (Jarvik, 1959). A few species (e.g., Birkenia elegans, Kerreralepis carinata, Pterygolepis nitida) possess a series of plates or spines inserted anteriorly to the anus, which Blom (2012) interpreted as a possible median preanal fin. A long and low dorsal fin has been described for Achanarella trewini (Newman, 2002), Endeiolepis aneri (Arsenault \& Janvier, 1991; Janvier, 1996b; Newman \& Trewin, 2001; Robertson, 1941; Stensiö, 1939; White, 1946) and Jamoytius kerwoodi (Janvier, 1981b; Ritchie, 1968a; White, 1946). In Euphanerops longaevus, a dorsal fin has been reported either as present (Arsenault \& Janvier, 1991; Stensiö, 1939; Woodward, 1900a) or absent (Janvier \& Arsenault, 2007; Sansom, Gabbott, \& Purnell, 2013). A recent re-investigation of the Euphanerops material confirms that a long and low dorsal fin is indeed present (Chevrinais et al., 2018). Furthermore, it has been proposed that En. aneri might actually represent a junior synonym for Eu. longaevus (Janvier, 2008; Janvier \& Arsenault, 2007; Janvier, Desbiens, Willett, \& Arsenault, 2006; Sansom et al., 2013); however, this hypothesis has not yet been the subject of a thorough investigation. In other anaspids, a dorsal fin is generally absent although some consider that the series of dorsal and/or ventral scutes represent reductions of what was originally dorsal or ventral fin-folds (Forey, 1995; Moy-Thomas \& Miles, 1971; Ritchie, 1964, 1968a; Stensiö, $1939,1964)$. Another interpretation is that the large epichordal lobe of the caudal fin is homologous to the second dorsal fin found in lampreys, osteostracans and gnathostomes (Arsenault \& Janvier, 1991; Blom \& Märss, 2010; Janvier, 1981b, 1996b, 2007, 2008; Jarvik, 1959), a hypothesis that seems unlikely but that cannot be rejected given that it has not been formally tested.

Many anaspids have paired ventrolateral fin-folds and/or triradiate spines that have been considered as possibly homologous to either the pectoral fins (Gagnier, 1993b; Kiaer, 1924; Robertson, 1938a, 1941; Stensiö, 1927, 1932), the pelvic fins (Janvier \& Arsenault, 2007; Moy-Thomas \& Miles, 1971; Wilson et al., 2007) or both paired fins (Stensiö, 1939). Homology of the paired ventrolateral fin-folds of anaspids with the metapleural folds of lancelets has also been suggested (Gagnier, 1993b; Westoll, 1958; Wickstead, 1969). Yet another hypothesis is that they represent independently derived structures (Coates, 2003; Hopson, 1974; Janvier, 1987; Ritchie, 1964; Robertson, 1941). Anaspid paired fins are found in a post-branchial position, and there are traces of endoskeletal supports for the fin-web (Gagnier, 1993b; Ritchie, 1964; Stensiö, 1964; Wilson et al., 2007). Some also consider that they were likely moveable structures under muscular control (Janvier, 1981b, 1984, 1987, 1996b; Ritchie, 1964; Wilson et al., 2007; contra Westoll, 1958). The 'pectoral spines' are generally interpreted as forming the leading edge of the ventrolateral fin-folds (e.g., Blom, 2008; Gagnier, 1993b; Janvier, 1996b; Kiaer, 1924; Moy-Thomas \& Miles, 1971; Ritchie, 1964, 1980). In most species, the paired fins are unconstricted and ribbon-like, with the exception of Pharyngolepis heintzii and Rhyncholepis parvulus (Blom et al., 2002; Janvier, 1981b, 1984; Moy-Thomas \& Miles, 1971; Ritchie, 1964, 1980) where they are much shorter. Blom (2012) argued that the evidence in favour of the paired lateral fin-folds described for Jamoytius and Euphanerops is inconclusive and that an alternative hypothesis is that these might actually be unpaired median structures. Based on a thorough examination of the Euphanerops material (Chevrinais et al., 2018), paired ventrolateral fins are indeed found to be present in euphaneropids, as suggested by Stensiö (1939) and Janvier and Arsenault (2007). Furthermore, these ventrolateral paired fins are subdivided into a series of finlets, each composed of a radial, a meso- or metapterygial-like element and several fin-rays (Chevrinais et al., 2018). Janvier (1996b) suggested that the posterior extent of the paired fins in anaspids may have been constrained by the position of the anus. However, it has recently been found that the structure originally described as an anal fin in Euphanerops is in fact a paired fin (Sansom et al., 2013). Paired anal fins are unique to Euphanerops among vertebrates, with the exception of some mutations in goldfish (Carassius auratus) and zebrafish (Danio rerio) that lead to duplicated anal and/ or caudal fin structures (Abe et al., 2014; Abe \& Ota, 2017).

\section{7 | Pteraspidomorphi}

The extinct Pteraspidomorphi comprise four orders (Astraspidiformes, Arandaspidiformes, Cyathaspidiformes and Pteraspidiformes), most of which are known only from the remains of the cephalothoracic shield. The Astraspidiformes currently include only two species from the Ordovician of North America and Siberia (Janvier, 11996a;; Janvier, 1996b), among which Astraspis desiderata is the best known. Astraspis has a caudal fin but no other median or paired fins (Elliott, 1987; Gagnier, 1993a, 1993b; Lehtola, 1983; Sansom, Smith, Smith, \& Turner, 1997; Soehn \& Wilson, 1990). Some of the earliest undisputed vertebrate remains, from the Lower Ordovician of Australia, have been assigned to the arandaspid genus Porophoraspis (Young, 1997). However, articulated postcranial material is known only for two species of Arandaspidiformes, Sacabambaspis janvieri from the Middle-Upper Ordovician of Bolivia (Gagnier, 1989, 1993b; Gagnier \& Blieck, 1992; Gagnier, Blieck, \& Rodrigo, 1986; Pradel, Sansom, Gagnier, Cespedes, \& Janvier, 2007) and Arandaspis prionotolepis from the Lower-Middle Ordovician of Australia (Ritchie, 1985; Ritchie \& Gilbert-Tomlinson, 1977). In Sacabambaspis, a caudal fin is present and there are dorsal and preanal crests and ridge scales along the dorsal and ventral midlines (Gagnier, 1993a, 1993b; Gagnier \& Blieck, 1992). As for Arandaspis, even in the best-preserved specimen, only a small part of the body posteriorly to the cephalothoracic shield is preserved so that 
nothing can be said concerning the shapes and arrangement of the fins (Ritchie, 1985; Ritchie \& Gilbert-Tomlinson, 1977).

The Cyathaspidiformes and Pteraspidiformes are generally referred to as heterostracans. Heterostracans appeared during the Lower Silurian and their stratigraphic range extends to the Upper Devonian (Janvier, 1996b; Žigaitè \& Blieck, 2013). They are extremely conservative in terms of fin configurations: all median and paired fins are absent with the exception of the caudal fin (Stensiö, 1964; White, 1935). Lateral extensions of the shield are present in some taxa and would have served as an aid in stability (the cornual plates of pteraspids and branchial plates of psammosteids) but these structures were generally not moveable (Halstead, 1973; Halstead \& Turner, 1973; Janvier \& Blieck, 1979; Westoll, 1958), with the possible exception of the branchial plates in Psammosteus kiaeri (Tarlo, 1964, 1965). Some authors have suggested that heterostracans retain a median ventral fin-fold in the form of a ventral crest composed of scales (Blieck, 1984; Janvier \& Blieck, 1979; Stensiö, 1964). Stensiö (1964) also interpreted the median dorsal crest scales as representing a dorsal fin-fold. We consider these interpretations unlikely since scales or scutes arranged along the midline are present in other taxa and they are unquestionably not considered as fins (e.g., sturgeons [Acipenseriformes] and lumpsuckers [Cyclopteridae] have dorsal scutes; anchovies, herrings and sardines [Clupeiformes] generally have ventral scutes).

\section{8 | 'Thelodonti'}

The stratigraphic range of the 'Thelodonti' ( 6 orders, 132 described species [Märss et al., 2007]) extends from the Middle Ordovician to the Upper Devonian (Märss et al., 2007). All thelodonts so far described possess a caudal fin. A dorsal fin is generally present, but can be lacking in some Thelodontiformes and Furcacaudiformes. Some authors have also speculated that the epichordal lobe of at least some thelodonts could be homologous to the second dorsal fin of osteostracans and gnathostomes (van der Brugghen, 1994; Janvier 1981b). An anal fin has been identified in all thelodonts where this region of the body is sufficiently well preserved, with the exception of the Furcacaudiformes where it is entirely absent (Märss et al., 2007). A possible preanal fin has been suggested for Furcacauda fredholmae, in the form of a rounded fin-like extension immediately anterior to the anal opening (Wilson \& Caldwell, 1998). However, this feature has been observed in a single specimen and the authors expressed doubt in its interpretation as a median ventral fin (Wilson \& Caldwell, 1998)

With the exception of two species of Furcacaudiformes, Sphenonectris turnerae and Pezopallichthys ritchiei (Märss et al., 2007; Wilson \& Caldwell, 1993, 1998), paired fins are generally present in thelodonts. However, the homology of these paired fins remains an open debate. Their insertion close to the branchial region prompted some authors to consider these paired fins as homologous to pectoral fins (e.g., Märss \& Ritchie, 1998; Novitskaya \& Turner, 1998; Powrie, 1870; Stensiö, 1927; Traquair, 1900; Turner, 1991, 1992; Turner \& van der Brugghen, 1993; Turner \& Young, 1992; Wilson \& Märss, 2012).
Other authors have been more cautious in their interpretation, while still recognizing the similarity in positioning by referring to these lateral expansions as 'suprabranchial fins' (Johanson, 2010; Wilson et al., 2007), 'pectoral flaps' (Dineley \& Loeffler, 1976; Donoghue \& Smith, 2001; Märss et al., 2007; Ritchie, 1968b; Turner, 1982), 'pectoral swimming appendages' (Stensiö, 1964) or 'pectoral-level fins' (Coates, 2003). Wilson and Caldwell (1998) argued that the paired fins of traditional thelodonts (i.e., excluding the Furcacaudiformes) are inserted dorsally relative to the branchial openings making their homology to pectoral fins questionable. Another opinion is that these scale-covered lateral flaps should not be considered as 'true fins' (Woodward, 1900b). Moy-Thomas and Miles (1971) expressed doubt regarding the mobility of these structures and instead considered them as possibly homologous to the cornual or branchial plates of heterostracans. Alternatively, Turner $(1991,1992)$ suggested that the triangular flaps were likely flexible and that the linear arrangement of scales on their surface was indicative of an underlying cartilaginous or fibrous support; thus, they would not have differed from true fins at least from a functional and structural standpoint.

Among thelodonts, the Furcacaudiformes have unusual morphologies, which does not simplify the issue of homology with the paired fins of other agnathans. In their initial description of the group, Wilson and Caldwell (1993) stated that the ventrally positioned paired fins of furcacaudids are inserted below the branchial row and are difficult to homologize to the paired fins of other fishes. The posterior limit of these paired flaps is near the anus so that homology to either pectoral or pelvic fins of gnathostomes cannot be ruled out (Wilson \& Caldwell, 1998). Later, Wilson et al. (2007) proposed that the paired fins of most thelodonts have a suprabranchial insertion and could be precursors of pectoral fins, while the paired fins of furcacaudiforms (and of most anaspids) have a ventrolateral insertion and could be precursors of pelvic fins.

\section{9 | 'Cephalaspidomorphi'}

The extinct paraphyletic 'Cephalaspidomorphi' comprise the Galeaspida, Pituriaspida and Osteostraci. All of these forms are characterized by the presence of a large cephalothoracic shield covering the head and branchial regions.

The stratigraphic range of the Galeaspida ( 3 orders, $\sim 65$ described species [Zhu \& Gai, 2007]) extends from the Lower Silurian to the Upper Devonian, with all but one localities situated in China and northern Vietnam (Janvier, 1996b; Zhu \& Gai, 2007; Žigaitè \& Blieck, 2013). Galeaspids are known almost exclusively from their cephalic shields: articulated postcranial material is rare (Janvier, 1996b). So far, the trunk and caudal fin have been described only for Sanqiaspis rostrata (Liu, 1975). To our knowledge, there was never any evidence suggesting the presence of either dorsal (although the presence of two dorsal fins has been hypothesized for Shuyu zhejiangensis [Gai, Donoghue, Zhu, Janvier, \& Stampanoni, 2011; Gai, Zhu, $\&$ Zhao, 2005]) or anal fins in galeaspids and most authors generally consider that they were absent (e.g., Janvier, 1996a; Turner et al., 2010). There is, however, a small dorsal spine which is fused to 
the cephalic shield (Pan, 1992). There is also no evidence that paired fins were present in galeaspids (Forey, 1995; Forey \& Janvier, 1993; Janvier, 1981b, 1984, 1996b, 2007, 2008; Wilson et al., 2007). No visible pectoral fin attachment area can be seen, and there are no pectoral fenestrae in the posterolateral part of the shield (Janvier, 1984; Zhu \& Gai, 2007).

Pituriaspids are known from only two species (Pituriaspis doylei and Neevambaspis enigmatica) from a single Lower-Middle Devonian locality in Queensland, Australia (Janvier, 1996a; Young, 1991). Only Pituriaspis is sufficiently well preserved to allow interpretation of its general morphology, showing an attachment area for paired fins (Young, 1991). These fins can be interpreted as pectoral fins, owing to the positioning and morphology of the attachment area, which is shared with osteostracans, and to the close phylogenetic relationships between these two groups (Janvier, 2007; Young, 1991).

The Osteostraci (3-5 orders depending on recent classification, 214 species [Janvier, 1981a, 1985a, 1996b; Sansom, 2008, 2009]) range from the Middle Silurian to the Upper Devonian (Sansom, 2008; Žigaitè \& Blieck, 2013). Osteostracans are the second most diverse jawless group, following conodonts. In all osteostracans in which the post-cephalic region is sufficiently well known, a caudal fin is present and there are no median ventral or anal fins, although many taxa do present a horizontal lobe lining the caudal fin ventrally (Heintz, 1939, 1967), which some have suggested might represent a modified anal fin (Forey, 1995; Janvier, 1981b, 1996a, 2007, 1996b; Stensiö, 1932, 1964). Heintz (1939) considered that this horizontal lobe could not be homologized to the anal fin because the structure is distinctly paired and that it could also not be homologized to the pelvic fins because it is inserted posteriorly to the anus; he concluded that it might be an independently derived structure. Of course, the argument that the horizontal lobe cannot be homologized to an anal fin owing to its paired nature may have to be revisited given that a paired anal fin has been described in Euphanerops (Sansom et al., 2013). Westoll (1958) considered instead that the horizontal lobes of the caudal fin are posterior developments of the paired ventrolateral ridges lining the trunk (and also that the pectoral fins discussed below are anterior developments of these same ridges).

Most osteostracans have a single dorsal fin, although Ateleaspis tessellata, Aceraspis robustus and Hirella gracilis have anterior and posterior dorsal fins (Heintz, 1939; Ritchie, 1967). These species are considered as basal members of the Osteostraci (Blieck \& Janvier, 1991; Janvier, 1985a, 1996b, 1985c; Sansom, 2008, 2009), and the presence of two dorsal fins should thus be considered as plesiomorphic for the group (Janvier, 1981b). Osteostracans that have a single dorsal fin retain a series of median dorsal ridge scales along the trunk and tail (Heintz, 1967; Robertson, 1935b; Sansom, 2007; Stensiö, 1932; White, 1958), and the posterior end of the cephalic shield often presents a dorsal crest and/or a dorsal spine (Adrain \& Wilson, 1994; Dineley, 1994; Heintz, 1967; Keating, Sansom, \& Purnell, 2012; Robertson, 1935a, 1935b; Scott \& Wilson, 2012, 2013; White, 1958). The dorsal crest and spine of the cephalic shield have frequently been interpreted as remnants of the anterior dorsal fin found in basal osteostracans (Heintz, 1939, 1967; Kiaer, 1911; Stensiö, 1927,
1932, 1964; Wängsjö, 1952). One hypothesis is that the dorsal crest is a modification of the cephalic shield to accommodate the reduced anterior dorsal fin, which has been drawn inwards into the cephalic shield (Heintz, 1939; Kiaer, 1911). Another hypothesis is that the dorsal spine constitutes the anterior termination of a dorsal fin-fold, which is represented along the trunk of osteostracans by the crest formed by the dorsal ridge scales (Stensiö, 1932; Wängsjö, 1952). As of yet, neither of these scenarios has been validated.

Paired fins are generally present in osteostracans, although they are lacking in the Tremataspididae (Denison, 1951; Halstead \& Turner, 1973; Moy-Thomas \& Miles, 1971; Robertson, 1938a, 1938b; Stensiö, 1927, 1932). Tremataspids are derived members of the osteostracans, and so the absence of paired fins can be considered as a secondary loss rather than the plesiomorphic condition (Janvier, 1981a, 1985a, 1996b, 1985b, 1985c; Sansom, 2008, 2009; Stensiö, 1927, 1964; Wängsjö, 1952; contra Denison, 1951; Halstead, 1982; Westoll, 1945a, 1958). Although the prevailing view is now that the paired fins of osteostracans are homologous to pectoral fins, this has not always been the case. Lankester (1870) hypothesized that the function of these 'paired flaps' was to generate a current towards the branchial openings and that they were not involved in locomotion. Watson (1954) acknowledged the fin-like nature of these structures but considered that they were neomorphs and not homologous to the pectoral fins of gnathostomes. Concurring with Watson (1954), Janvier $(1978,1984)$ argued that the paired fins of osteostracans could not be considered as homologues of the gnathostome pectoral fins because they have an epibranchial insertion, whereas pectoral fins are always post-branchial structures. Osteostracan paired fins are anteriorly positioned, there are traces of muscular attachments and foramens for the passage of nerves and blood vessels (Janvier, 1978, 1996b; Janvier, Arsenault, \& Desbiens, 2004; Johanson, 2002), and there are endoskeletal supports (Janvier, 1996b; Janvier \& Arsenault, 1996; Janvier, Arsenault, et al., 2004). Furthermore, the endoskeletal shoulder girdle bears a strong resemblance to that of stem gnathostomes (scapulocoracoid with a monobasal articulation for the fin endoskeletal supports), most notably when compared to the shoulder girdle of antiarchs and various other placoderms (Goujet, 2001; Janvier, 2007; Janvier, Arsenault, et al., 2004; Johanson, 2002; Wilson et al., 2007). Based on these topological and structural observations, most authors agree that the paired fins of osteostracans are most likely homologous to the pectoral fins of gnathostomes (Forey, 1995; Forey \& Janvier, 1993, 1994; Janvier, 2007; Janvier \& Arsenault, 1996; Janvier, Arsenault, et al., 2004; Johanson, 2002; Kiaer, 1924; Maisey, 1986; Sansom, 2009; Stensiö, 1927, 1932, 1964; Wängsjö, 1952; Westoll, 1958). Other paired fins are absent although the body is triangular in cross section and the ventral angles expand into ventrolateral keels or ridges that extend posteriorly as far as the insertion of the tail (Adrain \& Wilson, 1994; Heintz, 1939; Moy-Thomas \& Miles, 1971; Ritchie, 1967; Stensiö, 1932, 1964; Westoll, 1958). These have been interpreted by some as remnants of ventrolateral fin-folds (Denison, 1951; Kiaer, 1924; Stensiö, 1932) or as rudimentary pelvic fins (Moy-Thomas \& Miles, 1971; Stensiö, 1932, 1964). 


\subsection{0 | 'Placodermi'}

The fossil record of placoderms ( 9 orders and 335 valid genera, most of which are monospecific [Denison, 1978; Young, 2010]) extends from the Lower Silurian to the end of the Devonian (Trinajstic Boisvert, Long, Maksimenko, \& Johanson, 2014; Young, 2010). Common to all placoderms that are sufficiently known from their postcranial anatomy is the presence of pectoral fins and a caudal fin. There is some disparity in placoderms as to the presence of an anal fin, pelvic fins and the number of dorsal fins.

Most placoderms have a single dorsal fin, although in the antiarch Remigolepis walkeri, it is absent (Johanson, 1997; Moloshnikov, 2008), and ptyctodontids have two dorsal fins. The antiarch Bothriolepis canadensis was originally described as having two dorsal fins (e.g., Patten, 1904; Stensiö, 1948), but later re-examinations of the material revealed that a single dorsal fin is present (Arsenault, Desbiens, Janvier, \& Kerr, 2004; Béchard, Arsenault, Cloutier, \& Kerr, 2014; Vézina, 1996). It is uncertain whether the most primitive placoderms (Stensioellida, Pseudopetalichthyida) had one or two dorsal fins because of the scarcity of articulated material from behind the thoracic shield (Denison, 1978; Janvier, 1996b). An anal fin is generally considered as absent in placoderms, although this may be partly owing to preservation issues as an anal fin has recently been described for the Upper Devonian arthrodire Africanaspis edmountaini (Gess \& Trinajstic, 2017). There are also some debates concerning the putative presence of an anal fin in two other arthrodires: in Coccosteus cuspidatus and Plourdosteus canadensis, a ventral bony plate has been described, facing the posterior limit of the dorsal fin (Heintz, 1931; Vézina, 1990, 1996; Watson, 1934). A possible interpretation is that it served as a basal plate supporting an anal fin (Carr, 1995; Heintz, 1938; Jarvik, 1960; Trinajstic et al., 2014; John Long, pers. comm.). However, no traces of an anal fin-web, of skeletal supports of any kind other than this plate, or of an attachment area for radials have ever been found so that other authors consider unlikely that it served as endoskeletal support for an anal fin (Heintz, 1931; Miles \& Westoll, 1968; Westoll, 1945b). Furthermore, Miles and Westoll (1968) postulated that this plate was too thin to provide support for a fin and considered instead that it most likely served as an area for an unspecified muscular attachment. Since the evidence is far from overwhelming in either case, the presence of an anal fin is dubious in Coccosteus and Plourdosteus.

Pelvic fins and/or girdles are known for most placoderm groups with the exception of petalichthyids, for which this feature has never been found, and antiarchs, where they were thought to be entirely absent (Arsenault et al., 2004; Trinajstic et al., 2014; Young, 2010; Zhu, Yu, Choo, Wang, \& Jia, 2012). As a possible exception within antiarch placoderms, pelvic flaps or fins had been suggested in B. canadensis (Patten, 1904; Stensiö, 1948; Vézina, 1996); however, these structures are now considered as a taphonomic artefact (Arsenault et al., 2004; Béchard et al., 2014). Recent findings by Zhu, Yu, Choo, Wang, and Jia (2012) suggest that the presence of pelvic fins might be plesiomorphic for the entire gnathostome clade and that their absence in some placoderms is due to secondary loss, a view shared with Young (2010) and Charest, Johanson, and Cloutier (2018).

\subsection{1 | 'Acanthodii'}

The fossil record of acanthodians, or 'spiny sharks', extends as far as the Upper Silurian (Burrow \& Rudkin, 2014; Hanke, 2008). Acanthodians comprise a little over 100 genera that have traditionally been divided into three orders: Acanthodiformes, Climatiiformes and Ischnacanthiformes (Denison, 1979; Janvier, 1996b; Miles, 1970, 1973; Moy-Thomas \& Miles, 1971; Zajíc, 1995, 1998; Zidek, 1993). However, many authors consider that the Diplacanthiformes constitutes a fourth order closely related to the Climatiiformes (Burrow, Blaauwen, Newman, \& Davidson, 2016; Burrow \& Turner, 2010; Burrow \& Young, 2012; Hairapetian, Valiukevičius, \& Burrow, 2006; Hanke, Davis, \& Wilson, 2001; Newman, Davidson, Den Blaauwen, \& Burrow, 2012). The monophyly of the Diplacanthiformes is well supported in recent phylogenetic analyses (e.g., Burrow et al., 2016; Burrow \& Turner, 2010; Davis, Finarelli, \& Coates, 2012; Dupret, Sanchez, Goujet, Tafforeau, \& Ahlberg, 2014; Hanke \& Davis, 2012; Hanke \& Wilson, 2004). It had been suggested by Gagnier and Wilson (1996) and Janvier (1996b) that the 'Climatiiformes', if not the entire 'Acanthodii', are paraphyletic, a hypothesis which is also well supported by recent phylogenetic investigations. Indeed, climatiiforms were resolved as paraphyletic by Burrow and Turner (2010) and Hanke and Wilson (2002, 2004). As for acanthodians, they have been resolved as either polyphyletic with some being stem chondrichthyans and others stem osteichthyans (Brazeau, 2009; Davis et al., 2012), or paraphyletic with respect to chondrichthyans (Brazeau \& de Winter, 2015; Burrow et al., 2016; Chevrinais, Sire, \& Cloutier, 2017; Giles, Friedman, \& Brazeau, 2015; Long et al., 2015; Qiao, King, Long, Ahlberg, \& Zhu, 2016; Zhu et al., 2013).

Acanthodians always have caudal, anal, dorsal and pectoral fins. Median and paired fins other than the caudal have spines at their leading edges, although a fin-web is not always present (Denison, 1979; Moy-Thomas \& Miles, 1971; Watson, 1937). Acanthodiforms possess a single dorsal fin, whereas climatiiforms and ischnacanthiforms have two dorsal fins. The absence of an anterior dorsal fin is considered as a derived condition in acanthodiforms (Burrow, 2004; Denison, 1979; Hanke, 2002). Acanthodians generally have pelvic fins, although members of the Acanthodidae lack paired pelvic fin spines (Beznosov, 2009; Burrow \& Young, 2005; Zajíc, 1995). Instead, Acanthodes species have a single ventral median spine inserted close behind the pectoral fins, often bearing a long and shallow fin-web (Beznosov, 2009; Heidtke, 1990; Zajíc, 1995, 1998). Despite that it is a median structure, Beznosov (2009) suggested a possible homology to the pelvic fin spines.

Many acanthodians also possess a series of up to six pairs of prepelvic (or intermediate) spines inserted ventrally between the pectoral and pelvic fins; prepelvic spines are generally small and only occasionally described as bearing a fin-web (Denison, 1979; Hanke, 2002; Hanke \& Wilson, 2006; Watson, 1937). The prepelvic fin spines may have acted as cutwaters or as defensive 
organs (Moy-Thomas \& Miles, 1971). It has also been suggested that such spines might have functioned as holdfasts in running waters (Gregory \& Raven, 1941), although we feel that this last hypothesis is unlikely. The presence of paired prepelvic spines is considered plesiomorphic for acanthodians, while their absence is derived (Denison, 1979; Gagnier, Hanke, \& Wilson, 1999; Hanke, 2002; Hanke \& Wilson, 2004; Moy-Thomas \& Miles, 1971; Warren, Currie, Burrow, \& Turner, 2000; Watson, 1937; Westoll, 1945b, 1958). Some authors have considered the hypothesis that the prepelvic fin spines were derived from an initially continuous lateral fin-fold: the fin-fold would have become divided and the spines would have subsequently developed (Dean, 1907; Kiaer, 1924; Ørvig, 1967; Watson, 1937; Westoll, 1945b). This scenario would be consistent with the lateral fin-fold hypothesis for the origin of paired fins (Balfour, 1876, 1878, 1881; Mivart, 1879; Thacher, 1877; see Section 4). Others found that the prepelvic fin spines of acanthodians offer little to no support for the lateral fin-fold hypothesis and instead proposed that they are special developments of the ventrolateral body ridges found, for instance, in cephalaspids (Miles, 1970, 1973; Westoll, 1958), a hypothesis which is neither parsimonious, nor likely. Several diplacanthids and climatiids also possess spines that are positioned anteriorly to the prepelvic spines and medially to the pectoral fin spines (Burrow, 2007; Burrow et al., 2016; Burrow, Newman, Davidson, \& Blaauwen, 2013; Denison, 1979; Ørvig, 1967; Watson, 1937), termed admedian spines, and/or spines that are generally positioned anteromedially to the pectoral fin spines (Brazeau, 2012; Burrow et al., 2013; Denison, 1979; Hanke \& Davis, 2008, 2012; Miles, 1973; Newman et al., 2012; Ørvig, 1967; Warren et al., 2000), termed prepectoral spines. Miles (1973) suggested that the pelvic, prepelvic and prepectoral fin spines formed a continuous series. Miles (1973) further hypothesized that the pectoral fins would have initially arisen within this continuous series, but would have subsequently migrated laterally, possibly for functional reasons. Another hypothesis is that the pelvic and prepelvic spines are serial homologues (Gagnier \& Wilson, 1996; Hanke \& Wilson, 2006), whereas the prepectoral spines are serial homologues of the pectoral spines (Gagnier \& Wilson, 1996). As for the admedian spines, they are generally considered as the most anterior elements of the prepelvic spine series (Gagnier \& Wilson, 1996; Hanke \& Davis, 2008; Hanke et al., 2001; Miles, 1973).

\subsection{2 | Chondrichthyes}

The fossil record of Chondrichthyes ( 33 orders of which 13-14 still have extant representatives; $\sim 3,000$ extinct species, $\sim 1,251$ extant species [Compagno, Dando, \& Fowler, 2005; Klimley, 2013; Nelson et al., 2016]) extends to the Lower Silurian, and possibly as far as the Upper or Middle Ordovician (Grogan, Lund, \& Greenfest-Allen, 2012; Hanke \& Wilson, 2010; Maisey, Miller, \& Turner, 2009; Miller, Cloutier, \& Turner, 2003; Sansom, Smith, \& Smith, 1996; Turner, 2004; Young, 1997). Chondrichthyans include sharks, skates, rays and chimaeras and are considered to have retained fin characteristics that are plesiomorphic for crown gnathostomes (Coates, 2003; Freitas, Zhang, \& Cohn, 2007; Mabee, 2000). They are characterized by having a cartilaginous skeleton with prismatic endoskeletal calcification and by males possessing modified myxopterygia, termed claspers, used for internal fertilization (Grogan \& Lund, 2004; Grogan et al., 2012; Maisey, 1984a, 1986; Schaeffer, 1981; Schaeffer \& Williams, 1977). Two main evolutionary lineages are recognized, the Euchondrocephali and the Elasmobranchii, which have been traditionally considered as sister groups (Grogan \& Lund, 2004; Grogan et al., 2012; Lund \& Grogan, 1997, 2004; Schaeffer \& Williams, 1977). This relationship is supported by most phylogenetic analyses (e.g., Grogan \& Lund, 2000, 2004; Grogan \& Lund, 2008; Inoue et al., 2010; Lund \& Grogan, 1997), although the Euchondrocephali have been found occasionally to be nested within a paraphyletic assemblage of elasmobranchs (e.g., Coates \& Sequeira, 2001a; Coates \& Sequeira, 2001b; Ginter, Hampe, \& Duffin, 2010). Furthermore, the phylogenetic position of the Iniopterygii, a clade of peculiar-looking fishes with enlarged pectoral fins that are inserted high along the side of the body (Grogan \& Lund, 2009; Zangerl, 1997; Zangerl $\&$ Case, 1973), is unclear. The iniopterygians are either considered to be nested within the Euchondrocephali (Grogan \& Lund, 2000, 2004; Lund \& Grogan, 1997), or they are stem chondrichthyans that diverged prior to the Euchondrocephali-Elasmobranchii split (Grogan \& Lund, 2009; Grogan et al., 2012; Lund, Grogan, \& Fath, 2014).

The Euchondrocephali include 12 orders among which only the Chimaeriformes contain extant species. They have a fossil record that extends to the Lower Carboniferous (Grogan \& Lund, 2004; Grogan et al., 2012; Lund \& Grogan, 1997). The more advanced forms, the Holocephali, are characterized by the presence of an erectile first dorsal fin spine that articulates, via a basal plate, with the dorsal process of the synarcual, a structure formed from the fusion of the anteriormost vertebrae (Didier, 1995; Didier, Kemper, \& Ebert, 2012; Maisey, 1986). The disparity in fin configurations observed in the Euchondrocephali results mostly from the dorsal fin(s), which can be present (either as a single fin or as two separate fins) or absent, and the presence/absence of the anal fin. The evidence as to the plesiomorphic number of dorsal fins in chondrichthyans is inconclusive. Lund (1985) wrote that arguments of equal weight could be made for the presence of a single dorsal fin, as in Xenacanthiformes, Heteropetalus and Chondrenchelyiformes, or two dorsal fins as in Cladoselache. Lund and Grogan (1997) later mentioned that the accumulated evidence seemed to support the elongation of the second dorsal fin into the single fin found in these taxa as a derived condition. The Euchondrocephali also include the Eugeneodontiformes, which is the only chondrichthyan order with pelvic fins absent.

The stem Elasmobranchii, ranging from the Devonian to the Cretaceous, comprise nine orders, but only four of these are represented by complete articulated postcranial material. Caudal, pectoral and pelvic fins are always present in these forms. Pectoral fin spines are known to occur in articulated specimens of Doliodus latispinosus (Omalodontiformes) from the Lower Devonian of Canada (Burrow, Turner, Maisey, Desbiens, \& Miller, 2017; Maisey et al., 
2017; Miller et al., 2003; Turner \& Miller, 2005) and Wellerodus priscus (Antarctilamniformes) from the Middle Devonian of the United States (Potvin-Leduc, 2017; Potvin-Leduc, Cloutier, Landing, VanAller Hernick, \& Mannolini, 2011). Based on the subsequent discovery of other putative chondrichthyans with pectoral finspines, it has also been suggested that a spine originally interpreted as forming the leading edge of a dorsal fin (Young, 1982, 1989) could be reinterpreted as a pectoral fin-spine in Antarctilamna prisca (Antarctilamniformes) from the Middle/Upper Devonian of Antarctica and Australia (Hanke \& Wilson, 2010; Miller et al., 2003; Wilson et al., 2007). There is some disparity as to the number of dorsal fins and the presence/absence of the anal fin. Additionally, the dorsal fin is described as entirely lacking in Thrinacodus (= Thrinacoselache) gracia (Phoebodontiformes; Ginter \& Turner, 2010; Grogan \& Lund, 2008).

The crown group Elasmobranchii are the Neoselachii, which include the Selachii and the Batoidea. The Neoselachii have a fossil record that extends as far as the Lower Jurassic (Grogan et al., 2012; Maisey, 1984b, 2012). The Selachii, or modern sharks, are fairly homogeneous in terms of fin configurations. As with stem Elasmobranchii, the caudal, pectoral and pelvic fins are always present. There are generally two dorsal fins, but there is a single dorsal fin in Hexanchiformes, and in some species of Synechodontiformes and Carcharhiniformes. The anal fin is present in most orders, although it is generally absent in the Squalomorphii (i.e., an anal fin is absent in Squaliformes, Protospinaciformes, Pristiophoriformes and Squatiniformes, but is present in Hexanchiformes), a condition which is considered as derived relatively to other neoselachians (Compagno, 1977).

Batoids comprise four orders that include about 630 species, representing close to half of extant chondrichthyan biodiversity (Aschliman, Claeson, \& McEachran, 2012). The fossil record of batoids extends to the Lower Jurassic (Maisey, 2012). Batoids possess highly derived paired fin morphologies and are much more disparate in their fin configurations than the Selachii. Again, the pectoral and pelvic fins are always present in batoids. The pectoral fins are connected to the antorbital process of the cranium and are generally greatly enlarged to the point of frequently being referred to as wings (Franklin, Palmer, \& Dyke, 2014; Rosenberger, 2001; Schaefer $\&$ Summers, 2005). The number of dorsal fins differs among species: it can be absent, and when present there can be one or two dorsal fins. The anal fin is also frequently absent, and in many species of Rajiformes and Myliobatiformes, the tail is long, whip-like and devoid of a terminal caudal web. In Myliobatiformes, some species bear spines or barbs with a dorsal insertion along the tail: there are generally one or two spines, occasionally three and rarely four or five (Amesbury \& Snelson, 1997; Halstead, 1978; Lowe et al., 2007; Thorson, Langhammer, \& Oetinger, 1988). The caudal spines are composed of a vitrodentine core with an external layer of enameloid and are anchored in a dense collagenous network of the dermis on the dorsal side of the caudal appendage (Amesbury \& Snelson, 1997; Halstead, 1978; Halstead, Ocampo, \& Modglin, 1955; Johansson, Douglass, \& Lowe, 2004). These caudal spines are thought to be modified placoid scales (Johansson et al., 2004; Kemp, 1999; Reif, 1982), and as such, they should not be considered as fins. Another issue concerning some Myliobatiformes pertains to the rostral or cephalic fins (Bigelow \& Schroeder, 1953; Fowler, 1941; Garman, 1913; Jordan \& Evermann, 1896; Smith, 1907; Tinker, 1944). These are extensions of the pectoral fins, which are interrupted on the sides of the head and reappear in front of the snout as fleshy protuberances (Garman, 1913; Meek \& Hildebrand, 1923; Mulvany \& Motta, 2013). Finally, a number of batoid taxa are also described as having lateral keels or ridges along the tail (e.g., Bean \& Weed, 1909a; Bean $\&$ Weed, 1909b; Bigelow \& Schroeder, 1958). These should probably not be considered as paired fins owing to their location along the tail, behind the insertion of the pectoral and pelvic fins.

A final source of disparity in fin configurations should be mentioned as it relates to the 'total group chondrichthyans'. This disparity concerns the presence of prepelvic fin spines between the pectoral and pelvic fins in at least two putative chondrichthyans, Kathemacanthus rosulentus and Seretolepis elegans, both from the Lower Devonian of the Northwest Territories, Canada (Gagnier \& Wilson, 1996; Hanke \& Wilson, 2010). A series of prepelvic spines have also recently been described in two stem elasmobranchs: D. latispinosus, which also possesses prepectoral and possibly admedian spines (Burrow et al., 2017; Maisey et al., 2017), and W. priscus (Potvin-Leduc, 2017). Notably, it has also been suggested based on the results of a phylogenetic analyses on cranial morphological characters that $D$. latispinosus may occupy a more stemward position in the chondrichthyan phylogeny, prior to the EuchondrocephaliElasmobranchii split (Maisey, Turner, Naylor, \& Miller, 2014; Pradel, Tafforeau, Maisey, \& Janvier, 2011). If acanthodians are added to the total group chondrichthyans as suggested by recent investigations (e.g., Brazeau \& de Winter, 2015; Burrow et al., 2016; Chevrinais et al., 2017; Giles, Friedman, et al., 2015; Long et al., 2015; Qiao et al., 2016), the presence of prepelvic spines will become a common character of stem chondrichthyans.

\subsection{3 | Actinopterygii}

Among fishes, actinopterygians, or ray-finned fishes, have achieved a remarkable ecological and evolutionary success (Lauder \& Liem, 1983), resulting in over 30,500 species (Nelson et al., 2016), as well as an abundant fossil record extending to the Upper Silurian (Cloutier \& Arratia, 2004). The diversity of actinopterygians represents close to half of all described vertebrate species. Not only are actinopterygians impressively species-rich, but they are also extremely morphologically disparate, and part of this disparity can readily be observed in differences in fin configurations. Indeed, many changes in modes of feeding and locomotion are associated with modifications of the structure, size, number and position of fins (Lauder \& Drucker, 2004; Lauder \& Liem, 1983; Webb, 1982, 1984).

Basal actinopterygians (i.e., excluding neopterygians) comprise two extant orders (Polypteriformes [bichirs and redfishes] and Acipenseriformes [sturgeons and paddlefishes]) and about ten extinct orders of fishes. The presence of a single dorsal fin has been 
considered as an actinopterygian synapomorphy (Cloutier \& Arratia, 2004). Dialipina salgueiroensis, one of the oldest putative actinopterygians from the Lower Devonian of Canada, has two dorsal fins (Schultze \& Cumbaa, 2001). However, since its description, phylogenetic investigations have placed Dialipina sometimes as a stem actinopterygian (Giles, Darras, Clement, Blieck, \& Friedman, 2015; Long et al., 2015; Schultze \& Cumbaa, 2001; Taverne, 1997; Zhu \& Schultze, 2001; Zhu, Yu, Wang, Zhao, \& Jia, 2006; Zhu et al., 2009), and other times as a stem osteichthyan (Brazeau, 2009; Brazeau \& de Winter, 2015; Burrow et al., 2016; Davis et al., 2012; Dupret et al., 2014; Friedman, 2007; Giles, Friedman, et al., 2015; Lu, Giles, Friedman, den Blaauwen, \& Zhu, 2016; Qiao et al., 2016). Other basal actinopterygians have a single dorsal fin, a single anal fin, a caudal fin and pectoral fins. The pelvic fins are sometimes lacking in a few species of Polypteriformes, 'Palaeonisciformes' and Tarrasiiformes.

Basal neopterygians include two extant orders (Lepisosteiformes [gars] and Amiiformes [bowfins]) as well as a dozen extinct orders. Their fin configurations resemble those of basal actinopterygians although to our knowledge, the loss of pelvic fins has not been observed in any of the described taxa. However, a second dorsal fin has been described for Placidichthys bidorsalis, which belongs to the extinct order lonoscopiformes (Brito, 2000).

The more advanced neopterygians are the teleosteans. Basal teleosteans are extremely diversified and include a number of very speciose marine and freshwater groups: notably the Osteoglossomorpha, Elopomorpha, Clupeomorpha and Ostariophysi. Among the Osteoglossomorpha (bony tongues and their allies), the Osteoglossiformes comprises species that use a mode of locomotion based on undulations of the anal fin (Notopteridae), or of the dorsal fin in the case of the monotypic family Gymnarchidae (Lindsey, 1978; McNeill Alexander, 1967). The fin that is used for propulsion is elongated in these forms and in some species, the pelvic, dorsal, anal and/or caudal fins can be lost.

The Elopomorpha (eels and their allies) are mostly fishes with an elongated body shape, and many species have developed an anguilliform mode of locomotion whereby the entire body is used in undulations that produce thrust (Lindsey, 1978; Sfakiotakis, Lane, \& Davies, 1999; Webb, 1975). As such, the dorsal and anal fins are often well developed and continuous with the caudal fin, while the paired fins are reduced or lost. The most disparate elopomorphs in terms of fin configurations belong to the order Anguilliformes. In Anguilliformes, the pelvic fins are always absent and, in many species, the pectoral fins are lost as well. Additionally, the median fins are frequently reduced to some extent or lost, and in some taxa, fins are entirely lacking in the adult (McCosker, 1977, 2004).

The Clupeomorpha (sardines and their allies) are comparatively far less disparate. The pelvic fins are frequently lost, and the reduction or loss of the dorsal fin is described for at least one species, Raconda russeliana (Gray, 1831). Furthermore, in species of Sundasalanx, a median ventral fin-fold is present, positioned between the pelvic and anal fins (Roberts, 1981; Siebert, 1997).

The Ostariophysi are extremely species-rich and are generally the group best represented in freshwater fish communities.
Ostariophysans correspondingly present very disparate fin configurations, particularly in the Siluriformes (catfishes), and to a lesser extent in the Gymnotiformes (knifefishes and their allies). In Siluriformes, loss of the dorsal, anal and/or pelvic fins is observed in many species. In the Eel catfish, Channallabes apus, the presence of the pectoral and pelvic fins varies intraspecifically: in some specimens, both paired fins are present, in others both paired fins are absent, and yet in others, only the pectoral fins are present (Adriaens, Devaere, Teugels, Dekegel, \& Verraes, 2002). In members of the Plotosidae, there is a second ray-supported dorsal fin which is confluent with the caudal and anal fins (Ferraris, 1999; Gormon, 1986; Jayaram, 1981, 1982; Nelson et al., 2016); it seems likely that this second dorsal fin is supported by a series of anteriorly expanding and enlarged upper procurrent rays of the caudal fin (Allen, 1998; Ferraris, 1999; Gormon, 1986). Members of the Gymnotiformes use an anal fin-based mode of locomotion (Lindsey, 1978; McNeill Alexander, 1967; de Santana, Vari, \& Wosiacki, 2013; Sfakiotakis et al., 1999; Webb, 1975), as with the previously mentioned Notopteridae. These two groups are not closely related (Alves-Gomes, 1999; Lavoué et al., 2012; Near et al., 2012); thus, their similarities in terms of body shape and anal fin-based propulsion have been independently acquired. Pelvic fins and a ray-supported dorsal fin have been lost in all Gymnotiformes, and the caudal fin is absent in four of the five families of this order.

Another source of disparity in ostariophysan fin configurations is the presence/absence of the adipose fin, which is usually a small, primitively non-rayed fin located medially between the dorsal and caudal fins (Aiello, Stewart, \& Hale, 2016; Buckland-Nicks, Gillis, \& Reimchen, 2012; Reimchen \& Temple, 2004; Stewart, 2015). The adipose fin first appears among the Ostariophysi (Characiformes and Siluriformes), but it is also found in several orders of more advanced Euteleostei (Argentiniformes, Salmoniformes and Osmeriformes) and Neoteleostei (Stomiiformes, Ateleopodiformes, Aulopiformes, Myctophiformes and Percopsiformes). These orders do not constitute a natural group, suggesting that the adipose fin might have evolved multiple times independently (Stewart, 2015; Stewart et al., 2014) or that it was secondarily lost in some groups (Esociformes, Lampridiformes). The adipose fin was hypothesized to be a degenerate appendage homologous to the posterior dorsal fin of basal gnathostomes (Bridge, 1904; Garstang, 1931). Later investigations suggested instead that the adipose fin is a novel structure and that its rudimentary appearance is the ancestral state for this appendage (Sandon, 1956; Stewart \& Hale, 2013; Stewart et al., 2014). Some euteleosteans possess a median ventral keel or fin-fold, often termed a ventral adipose fin, which is positioned anteriorly to the anal fin: this ventral fin has been described in some Osmeriformes, Stomiiformes, Aulopiformes and Gasterosteiformes (Fischer \& Bianchi, 1984; Froese \& Pauly, 2016; Greenwood et al., 1966; Nelson et al., 2016). In the Apteronotidae, a fleshy dorsal electroreceptive organ (also called 'dorsal filament' or 'dorsal thong') is present. Some have suggested that it might constitute a modified adipose fin (Boulenger, 1898; Kaup, 1856). The dorsal organ of apteronotids and the adipose fins of other ostariophysans share a similar position along 
the dorsal midline and are both scaleless and composed principally of connective and sensory tissues (Franchina \& Hopkins, 1996). Despite these similarities, Franchina and Hopkins (1996) found that the hypothesis of an evolutionary modification of the adipose fin and the hypothesis of an evolutionary novelty should be considered as equally parsimonious. An elongated adipose fin has also been described for a single fossil representative of the Gymnotiformes, Humboldtichthys kirschbaumi from the Upper Miocene of Bolivia, although the authors acknowledged that it corresponds topologically to the apteronotid dorsal electroreceptive organ (Gayet \& Meunier, 1991; Gayet, Meunier, \& Kirschbaum, 1994). Furthermore, it has been argued that the hypothesized adipose fin in Humboldtichthys could be a taphonomic artefact due to compression of the body outline (Albert, 2001; Albert \& Fink, 2007).

The more advanced teleosteans are the Euteleostei and the Neoteleostei. In addition to the dorsal and ventral adipose fins, the most notable source of disparity in fin configurations among the orders of basal euteleosteans and neoteleosteans is the occasional absence of pelvic fins. Among the Stomiidae, the pectoral fins are absent in late juveniles and adults of Photostomias, Idiacanthus and Tactostoma (Bolin, 1939; Fink, 1985; Goodyear \& Gibbs, 1986; Hulley, 1986; Kawaguchi \& Moser, 1984; Kenaley \& Hartel, 2005). In these genera, paddle-shaped pectoral fins are present in larvae and are gradually lost during metamorphosis (Kawaguchi \& Moser, 1984; Kenaley \& Hartel, 2005). Additionally, in the sexually dimorphic genus Idiacanthus, adult females only lack the pectoral fins, whereas males lack both pectoral and pelvic fins (Hulley, 1986). The reduction of the pectoral girdle and fins is an evolutionary trend among stomiids, which is partly owing to a co-option of some of the fin-rays as elements of a light-producing complex (Fink, 1985).

The more advanced Neoteleostei are the Acanthomorpha, which include the extremely species-rich Acanthopterygii. Acanthomorphs are characterized by the presence of spines in their dorsal and anal fins (Johnson \& Patterson, 1993). A major source of disparity in fin configurations among acanthomorphs concerns the median fins: there are frequently two separate dorsal or anal fins, and even occasionally a third dorsal fin, for instance in some Gadiformes (cods and their allies). Mabee, Crotwell, Bird, and Burke (2002) hypothesized that the spinous first dorsal fin of acanthomorphs may have arisen through duplication and divergence of the preexisting posterior dorsal fin module. The loss of fins also remains an important source of disparity in fin configurations in acanthomorphs. All of the median and paired fins can be lost, including the caudal fin in at least some species of six orders. Finally, in some groups, fins can be coopted to serve novel functions. Examples include the co-option of the first dorsal fin into a fishing apparatus (spines of the plesiomorphic spinous dorsal fin are modified into an illicium which serves as the rod, and an esca which is the bait) in anglerfishes (Lophiiformes; Lauder \& Liem, 1983; Pietsch, 1984; Pietsch \& Orr, 2007) or into a suctorial apparatus in remoras (Echeneidae, Perciformes; Britz \& Johnson, 2012; Friedman, Johanson, Harrington, Near, \& Graham, 2013; Fulcher \& Motta, 2006; O'Toole, 2002; Storms, 1888), or the co-option of the pelvic fins into a suctorial disk in lumpsuckers and snailfishes (Cyclopteridae and Liparidae respectively, both belonging to the Scorpaeniformes; Budney \& Hall, 2010; Gill, 1890; Voskoboinikova \& Kudryavtseva, 2014).

\subsection{4 | Sarcopterygii}

Sarcopterygians are a monophyletic group that includes lobe-finned fishes as well as all tetrapods (Cloutier \& Ahlberg, 1996; Janvier, 1996b; Schultze, 1986, 1993). For the purpose of this review, we will focus only on the piscine sarcopterygians ( 7 orders; 8 extant species; 190 extinct genera [updated from Cloutier \& Ahlberg, 1996]), which comprise only a few extant species but are nonetheless represented by a diversified fossil record extending as far as the Upper Silurian (Zhu \& Schultze, 1997). Sarcopterygians are generally characterized by having paired fins that are supported by a monobasal endoskeleton (Cloutier \& Ahlberg, 1996; Janvier, 1996b). However, the morphology of the pectoral girdle, and possibly also the pelvic girdle, in some stem sarcopterygians from China (i.e., Guiyu oneiros from the Upper Silurian and Psarolepis romeri from the Upper Silurian to Lower Devonian) suggests that the plesiomorphic condition for the group may have been a polybasal articulation (Zhu \& Yu, 2009; Zhu, Yu, Choo, Qu, et al., 2012; Zhu, Yu, Choo, Wang, et al., 2012). Guiyu, Psarolepis, Achoania and, more recently, Sparalepis tingi have been resolved as forming a clade of stem sarcopterygians (Choo et al., 2017), yet they present a mosaic of characters found in actinopterygians, sarcopterygians and even non-osteichthyan taxa (Zhu, Yu, \& Ahlberg, 2001; Zhu, Yu, Choo, Qu, et al., 2012; Zhu, Yu, Choo, Wang, et al., 2012; Zhu, Yu, \& Janvier, 1999; Zhu et al., 2009). These psarolepids, sensu Choo et al. (2017), share the characteristic of having spines at the leading edges of their pectoral, pelvic and both dorsal fins (Choo et al., 2017; Zhu, Yu, Choo, Qu, et al., 2012; Zhu, Yu, Choo, Wang, et al., 2012; Zhu et al., 2009).

The most basal sarcopterygian groups are the Onychodontiformes and the Actinistia. Onychodontiformes are known from only six genera, and their fossil record extends from the Lower to the Upper Devonian (Cloutier \& Ahlberg, 1996; Lu \& Zhu, 2010; Lu, Zhu, et al., 2016). Postcranial material is known only for a few species: they all have pectoral and pelvic fins, two dorsal fins, a single anal fin, and a caudal fin (Andrews, Long, Ahlberg, Barwick, \& Campbell, 2005; Jessen, 1966). Actinistians, or coelacanths, are known from two extant species, and their fossil record extends from the Lower Devonian to the Upper Cretaceous (Arratia \& Schultze, 2015; Cloutier \& Ahlberg, 1996; Cloutier \& Forey, 1991; Forey, 1998; Friedman, 2007; Johanson, Long, Talent, Janvier, \& Warren, 2006; Zhu, Yu, Choo, Wang, et al., 2012; Zhu, Yu, Lu, et al., 2012). Actinistians display little disparity in fin configurations, even in terms of the shape of individual fins with a few rare exceptions concerning caudal fin morphology (Cloutier, 1991, 1996; Forey, 1998; Wendruff \& Wilson, 2012). The generalized fin configuration observed in the extant Latimeria species is considered to be an example of conservative evolution, because it does not differ importantly from the fin configuration found in Carboniferous (Cloutier, 1991) and even some Devonian actinistians (e.g., Serenichthys kowiensis from the Upper Devonian of 
South Africa [Gess \& Coates, 2015], Diplocercides heiligenstockiensis [Jessen, 1966, 1973] and Diplocercides kayseri [von Koenen, 1895; Stensiö, 1937], the latter two from the Upper Devonian of Germany). Most actinistians typically have a triphycercal caudal fin that consists of symmetrical dorsal and ventral lobes separated by a smaller supplementary lobe that differs in size among species. However, some species have highly asymmetrical caudal fins where either the epichordal (e.g., Allenypterus; Piveteauia) or the hypochordal lobes (e.g., Miguashaia) are more developed (Cloutier, 1991; Forey, 1998). Uyeno (1991) suggested that what is considered as a trilobate caudal fin in Latimeria is actually a third dorsal and a second anal fin in which the rays are supported by pterygiophores, and these flank a small true caudal fin with rays unsupported by pterygiophores. However, this hypothesis does not hold with the evolution of caudal fin morphology in fossil actinistians. Actinistians are also characterized by the structural similarities between the endoskeleton of dorsal and anal fins and that of the paired fins (Ahlberg, 1992; Forey, 1998; Schultze, 1986).

The Dipnomorpha include the Porolepiformes and the Dipnoiformes. The fossil record of porolepiforms includes about eight genera and extends from the Lower to the Upper Devonian (Cloutier \& Ahlberg, 1996; Janvier, 1996b), although a possible Early Carboniferous occurrence has been recorded (Schultze, 1993). All porolepiforms have pectoral and pelvic fins, two dorsal fins, a single anal fin and a caudal fin. Porolepiforms are characterized as having widely differing paired fin morphologies: the pectoral fins are long, leaf-like and nearly symmetrical, while the pelvic fins are shorter, rounded and asymmetrical (Ahlberg, 1989). Furthermore, in the Upper Devonian Quebecius quebecensis, only the pectoral fins are lobed, whereas the pelvic fins are not (Cloutier \& Schultze, 1996). The Dipnoiformes, or lungfishes, include six living species and at least 81 genera with a fossil record extending to the Lower Devonian (Cloutier \& Ahlberg, 1996; Schultze, 1992). All dipnoans have lobed pectoral and pelvic fins, but there is some disparity in the configurations of the median fins, which creates difficulties in the interpretation of dorsal, anal and caudal fin characters. The Early Devonian Uranolophus wyomingensis has two dorsal fins (Denison, 1968), which is considered as the plesiomorphic condition for the group (Ahlberg \& Trewin, 1995; Schultze, 1986). The more derived dipnoans possess a single median fin that is continuous around the tail (Arratia, Schultze, \& Casciotta, 2001; Bemis, 1984; Friedman, 2010), and the caudal fin has changed from heterocercal to diphycercal (Johanson, Ericsson, Long, Evans, \& Joss, 2009). Friedman (2010) reviewed the evolutionary scenarios that have been proposed to explain the emergence of this continuous median fin in derived dipnoans, which he summarized as either: (1) reversal to a hypothetical ancestral protocercal condition (Bemis, 1984; Goodrich, 1930); (2) loss of the caudal and posterior expansion of the dorsal and anal fins (Abel, 1911; Arratia et al., 2001; Balfour \& Parker, 1882); (3) loss of dorsal and anal fins and anterior expansion of the caudal fin (Schmalhausen, 1913); (4) expansion of the plesiomorphic two narrow dorsal fins that fuse with the epichordal lobe of the caudal fin and loss of the anal fin (Dollo, 1895); or (5) consolidation of the dorsal, anal and caudal fins (Arratia et al., 2001; Long \& Clement, 2009; Westoll, 1949). Friedman (2010) concluded that hypotheses (1) through (3) were improbable and argued that out of the two remaining hypotheses, the prevalence of a regionalized endoskeleton supporting the hypochordal lobe favored incorporation of the anal fin rather than its loss. Contrastingly, in a detailed study of the ontogeny of Neoceratodus forsteri, Johanson et al. (2009) found better support for hypothesis (4). These latter authors suggest that the dorsal part of the diphycercal fin of Carboniferous and extant lungfishes is formed by the confluence of the two dorsal fins found in more basal members with the epichordal lobe of the caudal fin, whereas the ventral part of the fin is formed only by the hypochordal lobe, and the anal fin is lost entirely (Johanson et al., 2009).

The crown sarcopterygians are the Tetrapodomorpha. Piscine tetrapodomorphs include the Rhizodontiformes, 'Osteolepiformes' and 'Elpistostegalia'. In tetrapodomorphs, the paired fins are composed of robust endochondral elements (i.e., humerus, radius, ulna, femur, tibia, fibula) that can be homologized to those of the tetrapod limbs (Boisvert, 2005; Boisvert, Mark-Kurik, \& Ahlberg, 2008; Shubin, Daeschler, \& Jenkins, 2006, 2014; Vorobyeva \& Hinchliffe, 1996; Vorobyeva \& Schultze, 1991). Rhizodontiformes range from the Upper Devonian to the Lower Carboniferous, while 'Osteolepiformes' range from the lower Middle Devonian to the Lower Permian (Cloutier \& Ahlberg, 1996; Janvier, 1996b). Rhizodontiforms and osteolepiforms present the fin combinations characteristic of most sarcopterygian taxa: presence of pectoral and pelvic fins, two dorsal fins, a single anal fin and a caudal fin. The paraphyletic elpistostegalians include the closest relatives to tetrapods, and their fossil record extends from the Middle to the Upper Devonian (Cloutier \& Ahlberg, 1995, 1996; Daeschler, Shubin, \& Jenkins, 2006; Swartz, 2012). They are a poorly documented group and in the few taxa where postcranial material is preserved (e.g., Panderichthys, Tiktaalik, Elpistostege), there seems to be an evolutionary trend towards the loss of median fins other than the caudal fin (Daeschler et al., 2006; Shubin, Daeschler, \& Jenkins, 2014).

\section{4 | DISCUSSION}

In this paper, our main objectives were to summarize how fish appendages have historically been described in both fossil and extant taxa and to discuss putative homologies with the fins of gnathostomes whenever possible. To our knowledge, this is the most exhaustive review of the literature on the distribution of median and paired fins across such a wide phylogenetic span. We found that, when taking into account the phenomenal biodiversity and morphological disparity in fishes, not only does it become extremely difficult to interpret fin homologies, it is also arduous even to formulate an all-encompassing definition as to what constitutes a fin.

Among the factors that complicate inferring fin homologies are that fishes have highly diversified fin configurations and that some fin morphologies are restricted to certain taxonomic groups (e.g., preanal fin-fold of hagfishes, admedian and intermediate spines in 
acanthodians and stem chondrichthyans, adipose fins in teleosteans). The debate about fin homologies is further complicated because median and paired fins first appeared among agnathans, and the only extant representatives of these jawless fishes are hagfishes and lampreys, both of which exhibit character combinations that are not plesiomorphic for vertebrates (Furlong \& Holland, 2002; Janvier, 2008; Ota, Fujimoto, Oisi, \& Kuratani, 2013; Shimeld \& Donoghue, 2012). Developmental studies on these extant agnathans have nonetheless provided useful information as to the evolutionary history of fish appendages. Indeed, recent studies have shown that the absence of paired fins in lampreys is likely secondarily derived (Onimaru \& Kuraku, 2018; Tulenko et al., 2013). If anaspids continue to be well-supported as stem cyclostomes by future phylogenetic analyses, as suggested by Miyashita et al. (2019), this would provide additional weight to the hypothesis that the paired fins found in fossil agnathans (e.g., anaspids, thelodonts) can be homologized to the paired fins of gnathostomes, as opposed to structures that have independently evolved.

Despite the difficulties mentioned above, it is possible to construct a scenario whereby the different median and paired fins appeared in a stepwise manner (Larouche et al., 2017). For the median fins, developmental and palaeontological evidence suggests that they developed first as elongated structures before being modified into more constricted appendages. Indeed, median fins have been found to develop from a continuous fin-fold in lampreys (Freitas, Zhang, \& Cohn, 2006), chondrichthyans (Ballard, Mellinger, \& Lechenault, 1993) and actinopterygians (Abe, Ide, \& Tamura, 2007; Bemis \& Grande, 1999; van Eeden et al., 1996; Richter \& Moritz, 2017). However, this may not always be the case as Stewart, Bonilla, Ho, and Hale (2019) have found that adipose fins in Characoidei develop from fin-buds that appear after the reduction of the median larval fin-fold. As for palaeontological evidence, the most basal vertebrates from the fossil record are described as having elongated median fins that extend over most of the dorsal and ventral aspects of the fish (Shu et al., 1999; Shu, Morris, Han, et al., 2003; Hou et al., 2002; Zhang \& Hou, 2004). Lancelets also possess elongated median fin-folds that extend along the ventral and dorsal midlines leading to the hypothesis that these structures may be homologous (Schaeffer, 1987).

The situation is more difficult to interpret concerning the paired fins, and variants of two basic evolutionary scenarios have been proposed. One scenario is that the elongated paired fins described for many stem vertebrates (e.g., anaspids, furcacaudiforms) can be homologized to pelvic fins owing to their ventrolateral insertion (Wilson et al., 2007). Gnathostome pelvic fins also have a ventrolateral insertion, in contrast to pectoral fins that generally have a more lateral insertion close to the gill apertures. In this scenario, pelvic fins appeared before pectoral fins (Wilson et al., 2007). The other scenario is that pectoral fins appeared first among jawless fishes and pelvic fins appeared later among stem gnathostomes (Coates, 1993, 1994; Coates \& Cohn, 1998, 1999; Forey \& Janvier, 1993; Riley, Cloutier, \& Grogan, 2017; Ruvinsky \& Gibson-Brown, 2000; Shubin, Tabin, \& Carroll, 1997). This hypothesis is based largely on the observation that the osteostracan paired fins share anatomical and positional similarities with the paired fins of gnathostomes and are therefore interpreted by most authors as their homologs (Forey, 1995; Forey \& Janvier, 1993, 1994; Janvier, 2007; Janvier \& Arsenault, 1996; Janvier, Arsenault, et al., 2004; Johanson, 2002; Kiaer, 1924; Maisey, 1986; Sansom, 2009; Stensiö, 1927, 1932, 1964; Wängsjö, 1952; Westoll, 1958). Although the latter scenario has been more thoroughly discussed, it does not make explicit claims about the homologies of these elongated ventrolateral fins of some anaspids and thelodonts. One hypothesis is that paired fins first appeared as these elongated ribbon-like structures and were only later modified into narrow-based pectoral and pelvic fins (Larouche et al., 2017; Tabin \& Laufer, 1993). This hypothesis is reminiscent of the lateral fin-fold theory, an evolutionary scenario concerning the origin of the paired fins that Balfour, Mivart and Thacher independently proposed towards the end of the nineteenth century (Balfour, 1876, 1878, 1881; Mivart, 1879; Thacher, 1877). However, the expected archetypal vertebrate based on the fin-fold hypothesis, combining both median and lateral elongated fin-folds (Jarvik, 1980), has never been found in the fossil record. The contrasting view at the time was that paired fins evolved through the co-option of elements of the gill arches (Gegenbaur, 1876), a hypothesis that has recently seen some support from molecular data (Gillis, Dahn, \& Shubin, 2009). Based on our exhaustive review of the literature as well as the mapping of fin characters on a supertree of all fish orders (Larouche et al., 2017), we find that the evidence that would support a homology claim for the elongated ventrolateral paired fins of anaspids and furcacaudids is tenuous at best. Whether these ribbon-like paired appendages are homologous to the pectoral fins (Gagnier, 1993b; Kiaer, 1924; Robertson, 1938a, 1941; Stensiö, 1927, 1932), or the pelvic fins (Janvier \& Arsenault, 2007; Moy-Thomas \& Miles, 1971; Wilson et al., 2007), or both paired fins (Stensiö, 1939), or even whether they are independently derived structures (Coates, 2003; Hopson, 1974; Janvier, 1987; Ritchie, 1964; Robertson, 1941) is impossible to determine given the current evidence.

One hypothesis that would warrant further attention is that in some cases, it is not so much the fins themselves that are homologous across large phylogenetic scales, but rather the fin-forming fields. In support of this hypothesis, studies on several vertebrate models have shown that it is possible to induce the development of additional appendages along the flanks between the fore- and hindlimbs (Cohn, Izpisúa-Belmonte, Abud, Heath, \& Tickle, 1995; Isaac et al., 1998; Tamura et al., 2001; Tanaka et al., 2000, 2002; Yonei-Tamura et al., 2008). Similar methods have also been used to induce the development of an extra limb along the dorsal midline in chick embryos (Tamura et al., 2001; Yonei-Tamura et al., 2008, 1999). These fin-forming fields (or morphogenetic fields sensu Gilbert, Opitz, \& Raff, 1996) could explain how structural similarities can emerge in distinct appendages, more specifically through the redeployment of genetic mechanisms. The structural and functional similarities between the median and paired fins in coelacanths provide another example of the possible redeployment of 
developmental mechanisms. Ahlberg (1992) hypothesized that these similarities may be owing to a homeotic switch in gene expression whereby paired fin developmental mechanisms were re-expressed in the posterior dorsal and anal fins. Fin-forming fields could also explain how some fins might have evolved more than once independently during the evolutionary history of fishes. Indeed, despite similarities in structure and morphology, the adipose fin has been shown to have evolved independently multiple times within teleosteans (Stewart \& Hale, 2013; Stewart et al., 2014). This hypothesis may be extended to other appendages as well: pelvic claspers are considered as a synapomorphy of extant chondrichthyans (Grogan \& Lund, 2004; Grogan et al., 2012; Maisey, 1986; Schaeffer \& Williams, 1977), but intromittent organs have also been identified in various placoderms (Goujet, 1984, 2001; Miles \& Young, 1977; Trinajstic et al., 2014; Young, 1986) and more recently in the anaspid Euphanerops (Chevrinais et al., 2018). Although intromittent organs are present in these disparate taxa, their composition differs. In Euphanerops, the intromittent organs are associated with the pelvic girdles despite the fact that pelvic fins are absent (Chevrinais et al., 2018). In placoderms, the claspers are not part of the pelvic skeleton and are interpreted as serial homologues of the pectoral and pelvic fins (Long et al., 2015; Trinajstic et al., 2014). Lastly, in chondrichthyans, the claspers are a modification of the medial endoskeletal elements of the pelvic fins (O'Shaughnessy, Dahn, \& Cohn, 2015).

Another hypothesis that may explain both the disparity in fin configurations and the appearance of novel fins is that fins have a modular organization. Hypotheses of fin modules have already been proposed for both the median and the paired fins. In this context, the appearance of novel or additional fins could be facilitated by the duplication of preexisting fin modules. For the median fins (Figure 2), a dorsal and anal fin module has been proposed based on the observations that these fins share a symmetrical position along the anteroposterior body axis in basal teleosteans and that they show similarities in developmental patterns (Mabee et al., 2002). A caudal fin module has been suggested based on conserved developmental sequences and similarities in plastic responses to differences in flow regimes during ontogeny in the Arctic char (Salvelinus alpinus; Grünbaum, Cloutier, \& Vincent, 2012). The anterior dorsal fin has been interpreted as a novel fin module in both chondrichthyans (Maisey, 2009) and actinopterygians (Mabee et al., 2002). This anterior dorsal fin module may have evolved multiple times independently. In support of this hypothesis, although the developmental pattern for the anterior dorsal fin of most teleosteans is either bidirectional or directed anteroposteriorly for both radials and finrays, it has recently been shown that a third developmental pattern exists, exclusive to the spinous dorsal fin of Atheriniformes, whereby the pterygiophores sequentially develop in a posterior to anterior direction while the fin-rays develop in the opposite direction (Richter $\&$ Moritz, 2017). Finally, the adipose fin has also been proposed as a novel fin module that, as previously mentioned, might have evolved more than once (Stewart, 2015; Stewart et al., 2019, 2014).

Hypotheses of appendage modularity have also been discussed for the paired fins (Figure 3). For instance, developmental
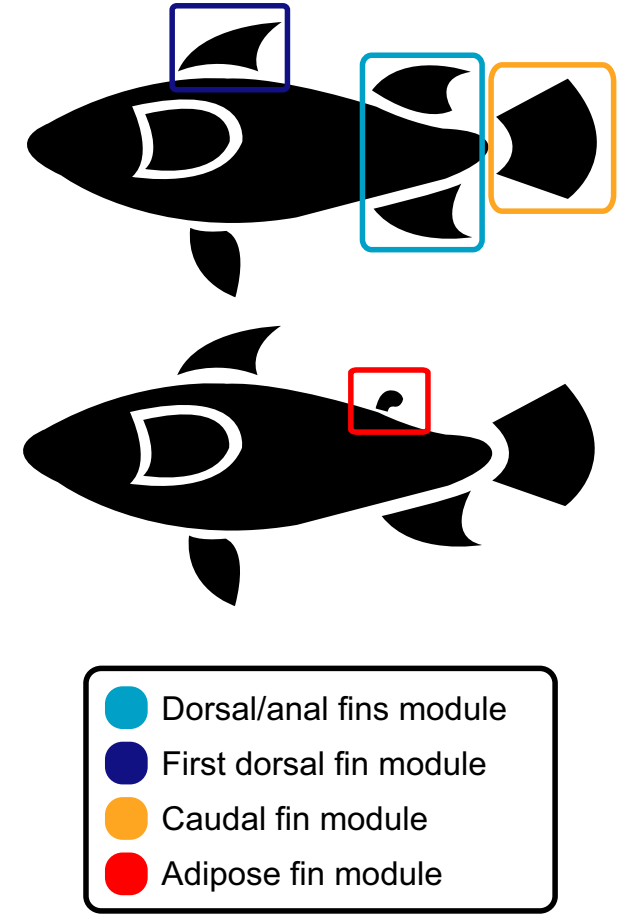

FIGURE 2 Hypothesized median fin modules. A dorsal and anal fin module has been proposed based on their symmetrical positioning relative to the anteroposterior body axis and on developmental similarities. A caudal fin module has been proposed based on conserved developmental mechanisms across species. The anterior dorsal and the adipose fins have both been interpreted as novel fin modules. See text for references [Colour figure can be viewed at wileyonlinelibrary.com]

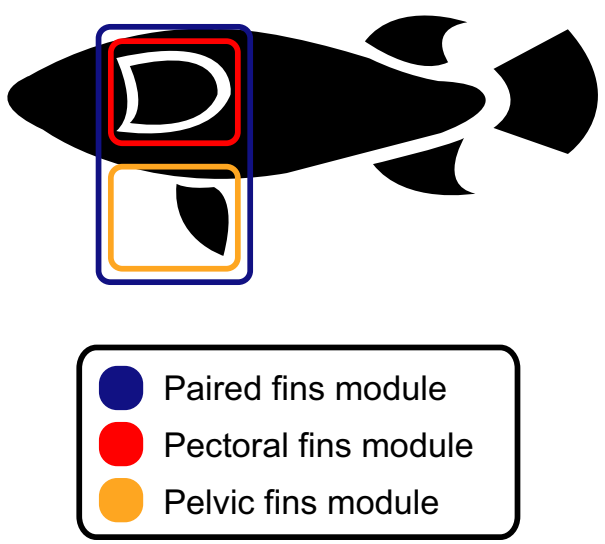

FIGURE 3 Hypothesized paired fin modules. The pectoral and pelvic fins have both become individuated as modules based on the fact that they can be modified or lost independently. However, strong covariation patterns in their presence/absence at a macroevolutionary scale suggest that they may be nested within a larger paired fin module. See text for references [Colour figure can be viewed at wileyonlinelibrary.com]

and structural similarities between median and paired fins have led some authors to suggest that median fin developmental mechanisms were redeployed laterally, leading to the emergence of the paired appendages (Freitas, Gómez-Skarmeta, \& Rodrigues, 2014; Freitas et al., 2006). Likewise, pectoral and pelvic fins display many 
developmental and morphological similarities in chondrichthyans, leading to the hypothesis that pectoral fin developmental mechanisms could have been re-expressed in the pelvic fins (Freitas et al., 2007; Riley et al., 2017). A paired fin module was further supported by highly significant covariance patterns in their presence/absence across fish orders (Larouche et al., 2017). Pectoral and pelvic fins can, however, both be individuated as modules hierarchically nested within the paired fins module, based on the observation that they can both be modified or lost independently (Hall, 2010).

Molecular mechanisms have been described that support these scenarios of modular duplication. For example, during median fin development, dorsal and anal fins have been shown to share similarities in gene expression patterns in the catshark (Freitas et al., 2006) and the zebrafish (Crotwell, Clark, \& Mabee, 2001; Crotwell, Sommervold, \& Mabee, 2004). For the paired fins, Tabin and Laufer (1993) hypothesized that the Hox genes controlling fin patterning in the pelvic fins were re-expressed in the pectoral fins in the lineage leading to tetrapods, thereby explaining structural similarities in paired fins in sarcopterygians. Moreover, two genes involved in fin positioning during development are Tbx5 for the pectoral fins and Tbx4 for the pelvic fins (Gibson-Brown et al., 1996). One hypothesis is that these two genes could have evolved through the duplication of a Tbx4/5 gene that controlled the position of the ancestral paired fin (Agulnik et al., 1996; Hadzhiev et al., 2007; Onimaru \& Kuraku, 2018; Ruvinsky \& Gibson-Brown, 2000; Tanaka et al., 2002). As previously mentioned, some authors have also proposed that the origin of the paired fins can be explained by the lateral redeployment of developmental mechanisms originally associated with the median fins (Crotwell et al., 2001; Crotwell \& Mabee, 2007; Freitas et al., 2014, 2006; Letelier et al., 2018). This hypothesis is supported by the similarities in molecular signalling pathways between developing median and paired fins (Abe et al., 2007; Freitas et al., 2014, 2006).

\section{5 | CONCLUSION}

In this paper, our main objective was to review the diversified fin configurations that occurred throughout the evolutionary history of fishes and to infer homologies wherever possible. We found that the disparity in fin number, position, structure and function greatly complicates not only interpreting fin homologies, but even formulating an all-encompassing definition of the term 'fin'. Based on the distribution of fin presence/absence on a supertree and the fin morphologies that are known for the most basal vertebrates, we favour a more conservative scenario where both median and paired fins first appeared as elongated structures that were later modified into shorter-based fins. We also suggest that it may be useful to discuss fin homologies in the context of fin-forming fields. Within this framework, median appendages would have appeared from a unique field of competence first positioned throughout the dorsal and ventral midlines, which was then redeployed laterally leading to the appearance of paired appendages. However, we realize that the available data are not sufficient to rule out other interpretations. We can only hope that future discoveries, whether developmental or palaeontological, will bring additional evidence leading to the resolution of this historical debate.

\section{ACKNOWLEDGEMENTS}

We are grateful to T. Grande and M.V.H. Wilson for their insightful comments on a first draft version of our manuscript. We also thank T. Stewart and one anonymous reviewer whose comments have greatly improved this manuscript. This research was partly funded by the Natural Sciences and Engineering Research Council of Canada (BESC-M and PGS-D to O.L.; NSERC Discovery Grant 238612 to R.C.) and the Fonds de Recherche Nature et Technologies Québec (B1 to O.L.)

\section{CONFLICT OF INTEREST}

The authors have no conflict of interest to declare.

\section{DATA AVAILABILITY STATEMENT}

Data sharing is not applicable to this article as no new data were created or analysed in this study.

\section{ORCID}

Olivier Larouche (iD https://orcid.org/0000-0003-0335-0682

\section{REFERENCES}

Abe, G., Ide, H., \& Tamura, K. (2007). Function of FGF signaling in the developmental process of the median fin fold in zebrafish. Developmental Biology, 304, 355-366. https://doi.org/10.1016/j. ydbio.2006.12.040

Abe, G., Lee, S. H., Chang, M., Liu, S. C., Tsai, H. Y., \& Ota, K. G. (2014). The origin of the bifurcated axial skeletal system in the twin-tail goldfish. Nature Communications, 5, 3360. https://doi.org/10.1038/ ncomms 4360

Abe, G., \& Ota, K. G. (2017). Evolutionary developmental transition from median to paired morphology of vertebrate fins: Perspectives from twin-tail goldfish. Developmental Biology, 427, 251-257. https://doi. org/10.1016/j.ydbio.2016.11.022

Abel, O. (1911). Grundzüge der Palaeobiologie der Wirbeltiere. Stuttgart, Germany: E. Schweirzerbart.

Adam, H., \& Strahan, R. (1963). Systematics and geographical distribution of myxinoids. In A. Brodal, \& R. Fänge (Eds.), The biology of myxine (pp. 1-8). Oslo, Norway: Universitetsforlaget.

Adrain, J. M., \& Wilson, M. V. H. (1994). Early Devonian cephalaspids (Vertebrata, Osteostraci, Cornuata) from the Southern Mackenzie Mountains, NWT, Canada. Journal of Vertebrate Paleontology, 14, 301-319. https://doi.org/10.1080/02724634.1994.10011561

Adriaens, D., Devaere, S., Teugels, G. G., Dekegel, B., \& Verraes, W. (2002). Intraspecific variation in limblessness in vertebrates: A unique example of microevolution. Biological Journal of the Linnean Society, 75, 367-377. https://doi.org/10.1111/j.1095-8312.2002. tb02078.x

Agulnik, S. I., Garvey, N., Hancock, S., Ruvinsky, I., Chapman, D. L., Agulnik, I., ...Silver, L. M. (1996). Evolution of mouse T-box genes by tandem duplication and cluster dispersion. Genetics, 144, 249-254. 
Ahlberg, P. E. (1989). Paired fin skeletons and relationships of the fossil group Porolepiformes (Osteichthyes: Sarcopterygii). Zoological Journal of the Linnean Society, 96, 119-166. https://doi. org/10.1111/j.1096-3642.1989.tb01824.x

Ahlberg, P. E. (1992). Coelacanth fins and evolution. Nature, 358, 459459. https://doi.org/10.1038/358459a0

Ahlberg, P. E., \& Trewin, N. H. (1995). The postcranial skeleton of the Middle Devonian lungfish Dipterus valenciennesi. Transactions of the Royal Society of Edinburgh: Earth Sciences, 85, 159-175. https://doi. org/10.1017/S0263593300003588

Aiello, B. R., Stewart, T. A., \& Hale, M. E. (2016). Mechanosensation in an adipose fin. Proceedings of the Royal Society B: Biological Sciences, 283, 20152794. https://doi.org/10.1098/rspb.2015.2794

Albert, J. S. (2001). Species diversity and phylogenetic systematics of American knifefishes (Gymnotiformes, Teleostei) (pp. 1-127). Miscellaneous Publications of the Museum of Zoology, University of Michigan.

Albert, J. S., \& Fink, W. L. (2007). Phylogenetic relationships of fossil neotropical electric fishes (Osteichthyes: Gymnotiformes) from the Upper Miocene of Bolivia. Journal of Vertebrate Paleontology, 27, 17-25. https://doi.org/10.1671/0272-4634(2007)27[17:profn e]2.0.co; 2

Aldridge, R. J. (1987). Conodont palaeobiology: A historical review. In R. J. Aldridge (Ed.), Palaeobiology of conodonts (pp. 11-34). Chichester UK: Ellis Horwood Ltd.

Aldridge, R. J., \& Briggs, D. E. G. (1990). Sweet talk. Paleobiology, 16, $241-$ 246. https://doi.org/10.1017/S0094837300009921

Aldridge, R. J., Briggs, D. E. G., Clarkson, E. N. K., \& Smith, M. P. (1986) The affinities of conodonts - New evidence from the Carboniferous of Edinburgh, Scotland. Lethaia, 19, 279-291. https://doi. org/10.1111/j.1502-3931.1986.tb00741.x

Aldridge, R. J., Briggs, D. E. G., Smith, M. P., Clarkson, E. N. K., \& Clark, N. D. L. (1993). The anatomy of conodonts. Philosophical Transactions of the Royal Society of London Series B. Biological Sciences, 340, 405-421. https://doi.org/10.1098/rstb.1993.0082

Aldridge, R. J., \& Purnell, M. A. (1996). The conodont controversies. Trends in Ecology \& Evolution, 11, 463-468. https://doi. org/10.1016/0169-5347(96)10048-3

Aldridge, R. J., Purnell, M. A., Gabbott, S. E., \& Theron, J. N. (1995). The apparatus architecture and function of Promissum pulchrum Kovacs-Endrody (Conodonta, Upper Ordovician) and prioniodontid plan. Philosophical Transactions of the Royal Society of London Series B. Biological Sciences, 347, 275-291. https://doi.org/10.1098/ rstb.1995.0027

Aldridge, R. J., \& Smith, M. P. (1993). Conodonta. In M. J. Benton (Ed.), The fossil record 2 (pp. 563-572). London, UK: Chapman \& Hall.

Aldridge, R. J., \& Theron, J. N. (1993). Conodonts with preserved soft tissue from a new Ordovician Konservat-Lagerstätte. Journal of Micropalaeontology, 12, 113-117. https://doi.org/10.1144/ jm.12.1.113

Allen, G. R. (1998). A review of the marine catfish genus Paraplotosus (Plotosidae) with the description of a new species from north-western Australia. The Raffles Bulletin of Zoology, 46, 123-134.

Alves-Gomes, J. A. (1999). Systematic biology of gymnotiform and mormyriform electric fishes: Phylogenetic relationships, molecular clocks and rates of evolution in the mitochondrial rRNA genes. Journal of Experimental Biology, 202, 1167-1183.

Amesbury, E., \& Snelson, F. F. (1997). Spine replacement in a freshwater population of the Atlantic stingray, Dasyatis sabina. Copeia, 1997, 220-223. https://doi.org/10.2307/1447863

Andrews, E. A. (1893). An undescribed acraniate: Asymmetron lucayanum. Studies from the Biological Laboratory of Johns Hopkins University, 5, 213-247.

Andrews, M., Long, J., Ahlberg, P., Barwick, R., \& Campbell, K. (2005). The structure of the sarcopterygian Onychodus jandemarrai $\mathrm{n}$. sp. from
Gogo, Western Australia: With a functional interpretation of the skeleton. Transactions of the Royal Society of Edinburgh-Earth Sciences, 96, 197-307. https://doi.org/10.1017/S0263593300001309

Aristotle, \& Barthélémy-Saint-Hilaire, J. (1883). Traités des parties des animaux et de la marche des animaux d'Aristote, Tome second. Paris, France: Librairie Hachette et Cie.

Aristotle, Cresswell, R., \& Schneider, J. G. (1878). Aristotle's history of animals in ten books. London, UK: George Bell \& Sons.

Arratia, G., \& Schultze, H.-P. (2015). A new fossil actinistian from the Early Jurassic of Chile and its bearing on the phylogeny of Actinistia. Journal of Vertebrate Paleontology, 35, e983524. https://doi. org/10.1080/02724634.2015.983524

Arratia, G., Schultze, H.-P., \& Casciotta, J. (2001). Vertebral column and associated elements in dipnoans and comparison with other fishes: Development and homology. Journal of Morphology, 250, 101-172. https://doi.org/10.1002/jmor.1062

Arsenault, M., Desbiens, S., Janvier, P., \& Kerr, J. (2004). New data on the soft tissues and external morphology of the antiarch Bothriolepis canadensis (Whiteaves, 1880), from the Upper Devonian of Miguasha, Quebec. In G. Arratia, M. V. H. Wilson, \& R. Cloutier (Eds.), Recent advances in the origin and early radiation of vertebrates (pp. 439-454). München, Germany: Verlag Dr. Friedrich Pfeil.

Arsenault, M., \& Janvier, P. (1991). The anaspid-like craniates of the Escuminac Formation (Upper Devonian) from Miguasha (Quebec, Canada), with remarks on anaspid-petromyzontid relationships. In M. M. Chang, Y. H. Liu, \& G. R. Zhang (Eds.), Early vertebrates and related problems of evolutionary biology (pp. 19-44). Beijing, China: Science Press.

Aschliman, N. C., Claeson, K. M., \& McEachran, J. D. (2012). Phylogeny of Batoidea. In J. C. Carrier, J. A. Musick, \& M. R. Heithaus (Eds.), Biology of sharks and their relatives (2nd ed., pp. 57-95). Boca Raton, FL: CRC Press.

Azariah, J. (1965). On the seasonal appearance of fin rays and their bearing on the reproductive cycle of Branchiostoma lanceolatum. Journal of the Marine Biological Association of India, 7, 459-461.

Balfour, F. M. (1876). The development of elasmobranch fishes. The Journal of Anatomy and Physiology, 11, 128-172.

Balfour, F. M. (1878). A monograph on the development of elasmobranch fishes. London, UK: MacMillan and Co.

Balfour, F. M. (1881). On the development of the skeleton of the paired fins of Elasmobranchii, considered in relation to its bearings on the nature of the limbs of the Vertebrata. Proceedings of the Zoological Society of London, 1881, 656-671.

Balfour, F. M., \& Parker, W. N. (1882). On the structure and development of Lepidosteus. Philosophical Transactions of the Royal Society of London, 173, 359-442. https://doi.org/10.1098/rstl.1882.0008

Ballard, W. W., Mellinger, J., \& Lechenault, H. (1993). A series of normal stages for development of Scyliorhinus canicula, the lesser spotted dogfish (Chondrichthyes, Scyliorhinidae). Journal of Experimental Zoology, 267, 318-336. https://doi.org/10.1002/jez.1402670309

Bardack, D. (1991). First fossil hagfish (Myxinoidea): A record from the Pennsylvanian of Illinois. Science, 254, 701-703. https://doi. org/10.1126/science.254.5032.701

Bardack, D. (1998). Relationships of living and fossil hagfishes. In J. M. Jørgensen, J. P. Lomholt, R. E. Weber, \& H. Malte (Eds.), The biology of hagfishes (pp. 3-14). London, UK: Chapman \& Hall.

Bardack, D., \& Richardson, E. S. (1977). New agnathous fishes from the Pennsylvanian of Illinois. Fieldiana, Geology, 33, 489-512.

Bardack, D., \& Zangerl, R. (1968). First fossil lamprey: A record from the Pennsylvanian of Illinois. Science, 162, 1265-1267. https://doi. org/10.1126/science.162.3859.1265

Bean, B. A., \& Weed, A. C. (1909a). Description of a new skate (Dactylobatus armatus) from deep water off the southern Atlantic coast of the United States. Proceedings of the United States National Museum, 36, 459-461. https://doi.org/10.5479/si.00963801.36-1682.459 
Bean, B. A., \& Weed, A. C. (1909b). Descriptions of two new species of electric rays, of the family Narcobatidae, from deep water off the southern Atlantic coast of the Unitd States. Proceedings of the United States National Museum, 36, 677-680. https://doi.org/10.5479/ si.00963801.36-1694.677

Béchard, I., Arsenault, F., Cloutier, R., \& Kerr, J. (2014). The Devonian placoderm fish Bothriolepis canadensis revisited with three-dimensional digital imagery. Palaeontologia Electronica, 17, 1-19. https://doi. org/10.26879/417

Belon, P. (1551). L'histoire naturelle des estranges poissons marins. Paris, France: Imprimerie de Regnaud Chaudiere.

Bemis, W. E. (1984). Paedomorphosis and the evolution of the Dipnoi. Paleobiology, 10, 293-307. https://doi.org/10.1017/S009483730 0008277

Bemis, W. E., \& Grande, L. (1999). Development of the median fins of the North American paddlefish (Polyodon spathula), and a reevaluation of the lateral fin-fold hypothesis. In G. Arratia, \& H.-P. Schultze (Eds.), Mesozoic fishes 2 - Systematics and fossil record (pp. 41-68). München, Germany: Verlag Dr. Friedrich Pfeil.

Bergström, J., Naumann, W. W., Viehweg, J., \& Martí- Mus, M. (1998). Conodonts, calcichordates and the origin of vertebrates. Fossil Record, 1, 81-91. https://doi.org/10.1002/mmng.19980010106

Berrill, N. J. (1930). Studies in tunicate development. Part I. General physiology of development of simple ascidians. Philosophical Transactions of the Royal Society B: Biological Sciences, 218, 37-78. https://doi. org/10.1098/rstb.1930.0002

Beznosov, P. (2009). A redescription of the Early Carboniferous acanthodian Acanthodes lopatini Rohon, 1889. Acta Zoologica, 90, 183-193. https://doi.org/10.1111/j.1463-6395.2008.00352.x

Bigelow, H. B., \& Farfante, I. P. (1948). Lancelets. In J. Tee-Van, C. M. Breder, S. F. Hildebrand, A. E. Parr, \& W. C. Schroeder (Eds.), Fishes of the Western North Atlantic. Part 1. Lancelets, cyclostomes, sharks (pp. 1-28). New Haven, CT: Sears Foundation for Marine Research, Yale University.

Bigelow, H. B., \& Schroeder, W. C. (1953). Sawfishes, guitarfishes, skates and rays. In J. Tee-Van, C. M. Breder, A. E. Parr, W. C. Schroeder, \& L. P. Schultz (Eds.), Fishes of the Western North Atlantic. Part 2. Sawfishes, guitarfishes, skates and rays, chimaeroids (pp. 1-514). New Haven, CT: Sears Foundation for Marine Research, Yale University.

Bigelow, H. B., \& Schroeder, W. C. (1958). Four new rajids from the Gulf of Mexico. Bulletin of the Museum of Comparative Zoology, 119, 201-233.

Blair, J. E., \& Hedges, S. B. (2005). Molecular phylogeny and divergence times of deuterostome animals. Molecular Biology and Evolution, 22, 2275-2284. https://doi.org/10.1093/molbev/msi225

Blieck, A. (1984). Les hétérostracés ptéraspidiformes, agnathes du SilurienDévonien du continent Nord-Atlantique et des blocs avoisinants: Révision systématique, phylogénie, biostratigraphie, biogéographie. Paris, France: Centre National de la Recherche Scientifique.

Blieck, A. (2011). From adaptive radiations to biotic crises in Palaeozoic vertebrates: A geobiological approach. Geologica Belgica, 14, 203-227.

Blieck, A., \& Janvier, P. (1991). Silurian vertebrates. Special Papers in Palaeontology, 44, 345-389.

Blieck, A., Turner, S., Burrow, C. J., Schultze, H.-P., Rexroad, C. B., Bultynck, P., \& Nowlan, G. S. (2010). Fossils, histology, and phylogeny: Why conodonts are not vertebrates. Episodes, 33, 234-241.

Blom, H. (2008). A new anaspid fish from the Middle Silurian Cowie Harbour fish bed of Stonehaven, Scotland. Journal of Vertebrate Paleontology, 28, 594-600. https://doi.org/10.1671/02724634(2008)28[594:anafft]2.0.co;2

Blom, H. (2012). New birkeniid anaspid from the Lower Devonian of Scotland and its phylogenetic implications. Palaeontology, 55, 641652. https://doi.org/10.1111/j.1475-4983.2012.01142.x
Blom, H., \& Märss, T. (2010). The interrelationships and evolutionary history of anaspids. In D. K. Elliott, J. G. Maisey, X. Yu, \& D. Miao (Eds.), Morphology, phylogeny and paleobiogeography of fossil fishes (pp. 45-58). München, Germany: Verlag Dr. Friedrich Pfeil.

Blom, H., Märss, T., \& Miller, C. G. (2002). Silurian and earliest Devonian birkeniid anaspids from the Northern Hemisphere. Transactions of the Royal Society of Edinburgh-Earth Sciences, 92, 263-323. https://doi. org/10.1017/S0263593300000250

Boisvert, C. A. (2005). The pelvic fin and girdle of Panderichthys and the origin of tetrapod locomotion. Nature, 438, 1145-1147. https://doi. org/10.1038/nature04119

Boisvert, C. A., Mark-Kurik, E., \& Ahlberg, P. E. (2008). The pectoral fin of Panderichthys and the origin of digits. Nature, 456, 636-638. https:// doi.org/10.1038/nature07339

Bolin, R. L. (1939). A new stomiatoid fish from California. Copeia, 1939, 39-41. https://doi.org/10.2307/1436014

Boulenger, G. A. (1898). On a collection of fishes from the Rio Jurua, Brazil. Transactions of the Zoological Society of London, 14, 421-427. https://doi.org/10.1111/j.1096-3642.1898.tb00064.x

Bourlat, S. J., Juliusdottir, T., Lowe, C. J., Freeman, R., Aronowicz, J., Kirschner, M., ...Telford, M. J. (2006). Deuterostome phylogeny reveals monophyletic chordates and the new phylum Xenoturbellida. Nature, 444, 85-88. https://doi.org/10.1038/nature05241

Brazeau, M. D. (2009). The braincase and jaws of a Devonian 'acanthodian' and modern gnathostome origins. Nature, 457, 305-308. https ://doi.org/10.1038/nature07436

Brazeau, M. D. (2012). A revision of the anatomy of the Early Devonian jawed vertebrate Ptomacanthus anglicus Miles. Palaeontology, 55, 355-367. https://doi.org/10.1111/j.1475-4983.2012.01130.x

Brazeau, M. D., \& de Winter, V. (2015). The hyoid arch and braincase anatomy of Acanthodes support chondrichthyan affinity of 'acanthodians'. Proceedings of the Royal Society B: Biological Sciences, 282, 20152210. https://doi.org/10.1098/rspb.2015.2210

Bridge, T. W. (1904). Fishes (Exclusive of the systematic account of Teleostei). In S. F. Harmer, \& A. E. Shipley (Eds.), The Cambridge Natural History (Vol. VII, pp. 141-537). London, UK: McMillan and Co. Limited.

Briggs, D. E. G. (1992). A major extinct group added to the vertebrates. Science, 256, 1285-1286. https://doi.org/10.1126/science.1598571

Briggs, D. E. G., Clarkson, E. N. K., \& Aldridge, R. J. (1983). The conodont animal. Lethaia, 16, 1-14. https://doi.org/10.1111/j.1502-3931.1983. tb01139.x

Briggs, D. E. G., \& Kear, A. J. (1994). Decay of Branchiostoma Implications for soft-tissue preservation in conodonts and other primitive chordates. Lethaia, 26, 275-287. https://doi. org/10.1111/j.1502-3931.1993.tb01532.x

Brito, P. M. (2000). A new halecomorph with two dorsal fins, Placidichthys bidorsalis n. g., n. sp. (Actinopterygii: Halecomorphi) from the Lower Cretaceous of the Araripe Basin, northeast Brazil. Comptes Rendus de l'académie des Sciences Série II Fascicule A - Sciences de la Terre et des Planètes, 331, 749-754. https://doi.org/10.1016/ s1251-8050(00)01477-4

Britz, R., \& Johnson, G. D. (2012). Ontogeny and homology of the skeletal elements that form the sucking disc of remoras (Teleostei, Echeneoidei, Echeneidae). Journal of Morphology, 273, 1353-1366. https://doi.org/10.1002/jmor.20063

Buckland-Nicks, J. A., Gillis, M., \& Reimchen, T. E. (2012). Neural network detected in a presumed vestigial trait: Ultrastructure of the salmonid adipose fin. Proceedings of the Royal Society B: Biological Sciences, 279, 553-563. https://doi.org/10.1098/rspb.2011.1009

Budney, L. A., \& Hall, B. K. (2010). Comparative morphology and osteology of pelvic fin-derived midline suckers in lumpfishes, snailfishes and gobies. Journal of Applied Ichthyology, 26, 167-175. https://doi. org/10.1111/j.1439-0426.2010.01398.x 
Burrow, C. J. (2004). Acanthodian fishes with dentigerous jaw bones: The Ischnacanthiformes and Acanthodopsis. Fossils and Strata, 50, 8-22.

Burrow, C. J. (2007). Early Devonian (Emsian) acanthodian faunas of the western USA. Journal of Paleontology, 81, 824-840. https://doi. org/10.1666/pleo06-009.1

Burrow, C. J., den Blaauwen, J., Newman, M., \& Davidson, R. (2016). The diplacanthid fishes (Acanthodii, Diplacanthiformes, Diplacanthidae) from the Middle Devonian of Scotland. Palaeontologia Electronica, 19, 1-83. https://doi.org/10.26879/601

Burrow, C. J., Newman, M. J., Davidson, R. G., \& den Blaauwen, J. L. (2013). Redescription of Parexus recurvus, an Early Devonian acanthodian from the Midland Valley of Scotland. Alcheringa, 37, 392414. https://doi.org/10.1080/03115518.2013.765656

Burrow, C. J., \& Rudkin, D. (2014). Oldest near-complete acanthodian: The first vertebrate from the Silurian Bertie Formation KonservatLagerstatte, Ontario. PLoS ONE, 9, e104171. https://doi.org/10.1371/ journal.pone.0104171

Burrow, C. J., \& Turner, S. (2010). Reassessment of "Protodus" scoticus from the Early Devonian of Scotland. In D. K. Elliott, J. G. Maisey, X. Yu, \& D. Miao (Eds.), Morphology, phylogeny and paleobiogeography of fossil fishes (pp. 123-144). München, Germany: Verlag Dr. Friedrich Pfeil.

Burrow, C. J., Turner, S., Maisey, J. G., Desbiens, S., \& Miller, R. F. (2017). Spines of the stem chondrichthyan Doliodus latispinosus (Whiteaves) comb. nov. from the Lower Devonian of eastern Canada. Canadian Journal of Earth Sciences, 54, 1248-1262. https://doi.org/10.1139/ cjes-2017-0059

Burrow, C. J., \& Young, G. C. (2005). The acanthodian fauna of the Craven Peaks Beds (Early to Middle Devonian), Western Queensland. Memoirs of the Queensland Museum, 51, 3-25.

Burrow, C. J., \& Young, G. C. (2012). New information on Culmacanthus (Acanthodii: Diplacanthiformes) from the ? Early-Middle Devonian of Southeastern Australia. Proceedings of the Linnean Society of New South Wales, 134, 21-29.

Capdevila, J., \& Izpesúa Belmonte, J. C. (2001). Patterning mechanisms controlling vertebrate limb development. Annual Review of Cell and Developmental Biology, 17, 87-132. https://doi.org/10.1146/annur ev.cellbio.17.1.87

Carr, R. K. (1995). Placoderm diversity and evolution. Bulletin du Muséun national d'Histoire naturelle. 4ieme Série. Section C, Sciences de la Terre, Paléontologie, Géologie, Minéralogie, 17, 85-125.

Chang, M. M., Wu, F. X., Miao, D. S., \& Zhang, J. Y. (2014). Discovery of fossil lamprey larva from the Lower Cretaceous reveals its threephased life cycle. Proceedings of the National Academy of Sciences of the United States of America, 111, 15486-15490. https://doi. org/10.1073/pnas.1415716111

Chang, M. M., Zhang, J. Y., \& Miao, D. D. (2006). A lamprey from the Cretaceous Jehol biota of China. Nature, 441, 972-974. https://doi. org/10.1038/nature04730

Charest, F., Johanson, Z., \& Cloutier, R. (2018). Loss in the making: Absence of pelvic fins and presence of paedomorphic pelvic girdles in a Late Devonian antiarch placoderm (jawed stem-gnathostome). Biology Letters, 14, 20180199. https://doi.org/10.1098/ rsbl.2018.0199

Chen, A. L., \& Huang, D. Y. (2006). Gill rays found on the early Cambrian primitive vertebrate Yunnanozoon. Acta Palaeontologica Sinica, 45 345-350. https://doi.org/10.3724/SP.J.1041.2013.00345

Chen, A. L., \& Huang, D. Y. (2008). Gill rays of primitive vertebrate Yunnanozoon from Early Cambrian: A first record. Frontiers of Biology in China, 3, 241-244. https://doi.org/10.1007/s11515-008-0020-3

Chen, J.-Y., Dzik, J., Edgecombe, G. D., Ramsköld, L., \& Zhou, G.-Q. (1995). A possible Early Cambrian chordate. Nature, 377, 720-722. https:// doi.org/10.1038/377720a0

Chen, J. Y., Huang, D. Y., \& Li, C. W. (1999). An early Cambrian craniate-like chordate. Nature, 402, 518-522. https://doi.org/10.1038/990080
Chen, J. Y., Huang, D. Y., Peng, Q. Q., Chi, H. M., Wang, X. Q., \& Feng, M. (2003). The first tunicate from the Early Cambrian of South China. Proceedings of the National Academy of Sciences of the United States of America, 100, 8314-8318. https://doi.org/10.1073/pnas.14311 77100

Chen, J. Y., \& Li, C. W. (1997). Early Cambrian chordate from Chengjiang, China. Bulletin of National Museum of Natural Sciences Taiwan, 10, 257-273.

Chevrinais, M., Johanson, Z., Trinajstic, K., Long, J., Morel, C., Renaud, C. B., \& Cloutier, R. (2018). Evolution of vertebrate postcranial complexity: Axial skeleton regionalization and paired appendages in a Devonian jawless fish. Palaeontology, 61, 949-961. https://doi. org/10.1111/pala.12379

Chevrinais, M., Sire, J. Y., \& Cloutier, R. (2017). From body scale ontogeny to species ontogeny: Histological and morphological assessment of the Late Devonian acanthodian Triazeugacanthus affinis from Miguasha, Canada. PLoS ONE, 12, e0174655. https://doi. org/10.1371/journal.pone.0174655

Choo, B., Zhu, M., Qu, Q. M., Yu, X. B., Jia, L. T., \& Zhao, W. J. (2017). A new osteichthyan from the late Silurian of Yunnan, China. PLoS ONE, 12, e0170929. https://doi.org/10.1371/journal.pone.0170929

Clements, T., Dolocan, A., Martin, P., Purnell, M. A., Vinther, J., \& Gabbott, S. E. (2016). The eyes of Tullimonstrum reveal a vertebrate affinity. Nature, 532, 500-503. https://doi.org/10.1038/nature17647

Cloney, R. A. (1982). Ascidian larvae and the events of metamorphosis. American Zoologist, 22, 817-826. https://doi.org/10.1093/ $\mathrm{icb} / 22.4 .817$

Cloutier, R. (1991). Patterns, trends, and rates of evolution within the Actinistia. Environmental Biology of Fishes, 32, 23-58. https://doi. org/10.1007/bf00007444

Cloutier, R. (1996). The primitive actinistian Miguashaia bureaui Schultze (Sarcopterygii). In H.-P. Schultze, \& R. Cloutier (Eds.), Devonian fishes and plants of Miguasha, Quebec, Canada (pp. 227-247). München, Germany: Verlag Dr. Friedrich Pfeil.

Cloutier, R., \& Ahlberg, P. E. (1995). Sarcopterygian interrelationships: How far are we from a phylogenetic consensus? Geobios, 6995(95), 241-248. https://doi.org/10.1016/S0016-6995(95)80121-9

Cloutier, R., \& Ahlberg, P. E. (1996). Morphology, characters, and the interrelationships of basal sarcopterygians. In M. L. J. Stiassny, L. R. Parenti, \& G. D. Johnson (Eds.), Interrelationships of fishes (pp. 445479). San Diego, CA: Academic Press.

Cloutier, R., \& Arratia, G. (2004). Early diversification of actinopterygians. In G. Arratia, M. V. H. Wilson, \& R. Cloutier (Eds.), Recent advances in the origin and early radiation of vertebrates (pp. 217-270). München, Germany: Verlag Dr. Friedrich Pfeil.

Cloutier, R., \& Forey, P. L. (1991). Diversity of extinct and living actinistian fishes (Sarcopterygii). Environmental Biology of Fishes, 32, 59-74. https://doi.org/10.1007/bf00007445

Cloutier, R., \& Schultze, H.-P. (1996). Porolepiform fishes (Sarcopterygii). In H.-P. Schultze, \& R. Cloutier (Eds.), Devonian fishes and plants of Miguasha, Quebec, Canada (pp. 248-270). München, Germany: Verlag Dr. Friedrich Pfeil.

Coates, M. I. (1993). Hox genes, fin folds and symmetry. Nature, 364, 195-196. https://doi.org/10.1038/364195b0

Coates, M. I. (1994). The origin of vertebrate limbs. Development, 1994(Suppl.), 169-180.

Coates, M. I. (2003). The evolution of paired fins. Theory in Biosciences, 122, 266-287. https://doi.org/10.1078/1431-7613-00087

Coates, M. I., \& Cohn, M. J. (1998). Fins, limbs, and tails: Outgrowths and axial patterning in vertebrate evolution. BioEssays, 20, 371-381. https://doi.org/10.1002/(sici)1521-1878(199805)20:5<371:aidbies4>3.0.co;2-r

Coates, M. I., \& Cohn, M. J. (1999). Vertebrate axial and appendicular patterning: The early development of paired appendages. American Zoologist, 39, 676-685. https://doi.org/10.1093/icb/39.3.676 
Coates, M. I., \& Sequeira, S. E. K. (2001a). Early sharks and primitive gnathostome interrelationships. In P. E. Ahlberg (Ed.), Major events in early vertebrate evolution: Palaeontology, phylogeny, genetics and development (pp. 241-262). London, UK: Taylor \& Francis.

Coates, M. I., \& Sequeira, S. E. K. (2001b). A new stethacanthid chondrichthyan from the Lower Carboniferous of Bearsden, Scotland. Journal of Vertebrate Paleontology, 21, 438-459. https://doi.org/10.1 671/0272-4634(2001)021[0438:anscft]2.0.co;2

Cohn, M. J., Izpisúa-Belmonte, J. C., Abud, H., Heath, J. K., \& Tickle, C. (1995). Fibroblast Growth Factors induce additional limb developement from the flank of chick embryos. Cell, 80, 739-746. https://doi. org/10.1016/0092-8674(95)90352-6

Compagno, L. J. V. (1977). Relationships of living sharks and rays. American Zoologist, 17, 303-322. https://doi.org/10.1093/icb/17.2.303

Compagno, L. J. V., Dando, M., \& Fowler, S. (2005). Sharks of the world. Princeton, NJ: Princeton University Press.

Cong, P. Y., Hou, X. G., Aldridge, R. J., Purnell, M. A., \& Li, Y. Z. (2015). New data on the palaeobiology of the enigmatic yunnanozoans from the Chengjiang Biota, Lower Cambrian, China. Palaeontology, 58, 45-70. https://doi.org/10.1111/pala.12117

Crotwell, P. L., Clark, T. G., \& Mabee, P. M. (2001). Gdf5 is expressed in the developing skeleton of median fins of late-stage zebrafish, Danio rerio. Development Genes and Evolution, 211, 555-558. https://doi. org/10.1007/s00427-001-0186-z

Crotwell, P. L., \& Mabee, P. M. (2007). Gene expression patterns underlying proximal-distal skeletal segmentation in late-stage zebrafish, Danio rerio. Developmental Dynamics, 236, 3111-3128. https://doi. org/10.1002/dvdy. 21352

Crotwell, P. L., Sommervold, A. R., \& Mabee, P. M. (2004). Expression of $b m p 2 a$ and $b m p 2 b$ in late-stage zebrafish median fin development. Gene Expression Patterns, 5, 291-296. https://doi.org/10.1016/j. modgep.2004.07.001

Cuvier, G. (1849). The animal kingdom, arranged after its organization, forming a natural history of animals and an introduction to comparative anatomy, 2nd ed. London, UK: WM. S. Orr and Co.

Cuvier, G., \& Duméril, M. (1835). Leçons d'anatomie comparée de Georges Cuvier. Paris, France: Crochard et Cie.

Cuvier, G., \& Valenciennes, M. (1828). Histoire naturelle des poissons, Tome premier. Paris, France: F.G. Levrault.

Daeschler, E. B., Shubin, N. H., \& Jenkins, F. A. (2006). A Devonian tetrapod-like fish and the evolution of the tetrapod body plan. Nature, 440, 757-763. https://doi.org/10.1038/nature04639

Davis, P. D., Finarelli, J. A., \& Coates, M. I. (2012). Acanthodes and sharklike conditions in the last common ancestor of modern gnathostomes. Nature, 486, 247-251. https://doi.org/10.1038/nature11080

de Santana, C. D., Vari, R. P., \& Wosiacki, W. B. (2013). The untold story of the caudal skeleton in the electric eel (Ostariophysi: Gymnotiformes: Electrophorus). PLoS ONE, 8, e68719. https://doi.org/10.1371/journ al.pone.0068719

Dean, B. (1907). Notes on acanthodian sharks. American Journal of Anatomy, 7, 209-222. https://doi.org/10.1002/aja.1000070204

Delarbre, C., Gallut, C., Barriel, V., Janvier, P., \& Gachelin, G. (2002). Complete mitochondrial DNA of the hagfish, Eptatretus burgeri: The comparative analysis of mitochondrial DNA sequences strongly supports the cyclostome monophyly. Molecular Phylogenetics and Evolution, 22, 184-192. https://doi.org/10.1006/mpev.2001.1045

Delsuc, F., Brinkmann, H., Chourrout, D., \& Philippe, H. (2006). Tunicates and not cephalochordates are the closest living relatives of vertebrates. Nature, 439, 965-968. https://doi.org/10.1038/nature04336

Delsuc, F., Tsagkogeorga, G., Lartillot, N., \& Philippe, H. (2008). Additional molecular support for the new chordate phylogeny. Genesis, 46, 592604. https://doi.org/10.1002/dvg.20450

Denison, R. H. (1951). Evolution and classification of the Osteostraci. Fieldiana, Geology, 11, 157-196. https://doi.org/10.5962/bhl. title.3286
Denison, R. H. (1968). Early Devonian lungfishes from Wyoming, Utah and Idaho. Fieldiana, Geology, 17, 353-413.

Denison, R. H. (1978). Volume 2 - Placodermi. Stuttgart, Germany: Gustav Fischer Verlag.

Denison, R. H. (1979). Volume 5 - Acanthodii. Stuttgart, Germany: Gustav Fischer Verlag.

Didier, D. A. (1995). Phylogenetic systematics of extant chimaeroid fishes (Holocephali, Chimaeroidei). American Museum Novitates, 3119, 1-86.

Didier, D. A., Kemper, J. M., \& Ebert, D. A. (2012). Phylogeny, biology, and classification of extant holocephalans. In J. C. Carrier, J. A. Musick, \& M. R. Heithaus (Eds.), Biology of sharks and their relatives (2nd ed., pp. 97-122). Boca Raton, FL: CRC Press.

Dineley, D. L. (1994). Cephalaspids from the Lower Devonian of Prince of Wales Island, Canada. Palaeontology, 37, 61-70.

Dineley, D. L., \& Loeffler, E. J. (1976). Ostracoderm faunas from the Delorme and associated Siluro-Devonian formations, North West Territories, Canada. Special Papers in Palaeontology, 18, 1-214.

Dingerkus, G. (1979). Chordate cytogenetic studies: An analysis of their phylogenetic implications with particular reference to fishes and the living coelacanth. Occasional Papers of the California Academy of Sciences, 134, 111-127.

Dollo, L. (1895). Sur la phylogénie des dipneustes. Bulletin de la Société Belge de Géologie, de Paléontologie et d'Hydrologie, 9, 79-128.

Donoghue, P. C. J., Forey, P. L., \& Aldridge, R. J. (2000). Conodont affinity and chordate phylogeny. Biological Reviews of the Cambridge Philosophical Society, 75, 191-251. https://doi.org/10.1017/s0006 323199005472

Donoghue, P. C. J., Purnell, M. A., \& Aldridge, R. J. (1998). Conodont anatomy, chordate phylogeny and vertebrate classification. Lethaia, 31, 211-219. https://doi.org/10.1111/j.1502-3931.1998.tb00509.x

Donoghue, P. C. J., \& Smith, M. P. (2001). The anatomy of Turinia pagei (Powrie), and the phylogenetic status of the Thelodonti. Transactions of the Royal Society of Edinburgh-Earth Sciences, 92, 15-37. https:// doi.org/10.1017/S026359330000002X

Duméril, A. M. C. (1806). Zoologie analytique, ou méthode naturelle de classification des animaux. Paris, France: Imprimerie de H. L. Perronneau.

Dunn, C. W., Hejnol, A., Matus, D. Q., Pang, K., Browne, W. E., Smith, S. A., ...Giribet, G. (2008). Broad phylogenomic sampling improves resolution of the animal tree of life. Nature, 452, 745-749. https://doi. org/10.1038/nature06614

Dupret, V., Sanchez, S., Goujet, D., Tafforeau, P., \& Ahlberg, P. E. (2014). A primitive placoderm sheds light on the origin of the jawed vertebrate face. Nature, 507, 500-503. https://doi.org/10.1038/nature12980

Dzik, J. (1991). Evolution of oral apparatuses in the conodont chordates. Acta Palaeontologica Polonica, 36, 265-323.

Dzik, J. (1995). Yunnanozoon and the ancestry of chordates. Acta Palaeontologica Polonica, 40, 341-360.

Ehehalt, F., Wang, B. G., Christ, B., Patel, K., \& Huang, R. J. (2004). Intrinsic cartilage-forming potential of dermomyotomal cells requires ectodermal signals for the development of the scapula blade. Anatomy and Embryology, 208, 431-437. https://doi.org/10.1007/ s00429-004-0415-0

Elliott, D. K. (1987). A reassessment of Astraspis desiderata, the oldest North American vertebrate. Science, 237, 190-192. https://doi. org/10.1126/science.237.4811.190

Fernholm, B. (1998). Hagfish systematics. In J. M. Jørgensen, J. P. Lomholt, R. E. Weber, \& H. Malte (Eds.), The biology of hagfishes (pp. 33-44). London, UK: Chapman \& Hall.

Ferraris, C. (1999). Plotosidae. In K. E. Carpenter, \& V. H. Niem (Eds.), $F A O$ species identification guide for fishery purposes. The living marine ressources of the western Central Pacific. Volume 3. Batoid fishes, chimaeras and bony fishes part 1 (Elopidae to Linophrynidae) (pp. 18801883). Rome, Italy: Food and Agriculture Organization of the United Nations. 
Fink, W. L. (1985). Phylogenetic interrelationships of the stomiid fishes (Teleostei: Stomiiformes). Miscellaneous Publications of the Museum of Zoology, University of Michigan, 171, 1-127.

Fischer, W., \& Bianchi, G. (Eds.) (1984). FAO species identification sheets for fishery purposes: Western Indian Ocean (Fishing Area 51). Vols. 1-6. Rome, Italy: Food and Agricultural Organization of the United Nations.

Forey, P. L. (1984). Yet more reflections on agnathan-gnathostome relationships. Journal of Vertebrate Paleontology, 4, 330-343. https://doi. org/10.1080/02724634.1984.10012013

Forey, P. L. (1995). Agnathans recent and fossil, and the origin of jawed vertebrates. Reviews in Fish Biology and Fisheries, 5, 267-303. https:// doi.org/10.1007/bf00043003

Forey, P. L. (1998). History of the Coelacanth fishes. London, UK: Chaman $\&$ Hall.

Forey, P. L., \& Janvier, P. (1993). Agnathans and the origin of jawed vertebrates. Nature, 361, 129-134. https://doi.org/10.1038/361129a0

Forey, P. L., \& Janvier, P. (1994). Evolution of the early vertebrates. American Scientist, 82, 554-565.

Fowler, H. W. (1941). Contributions to the biology of the Philippine Archipelago and adjacent regions. The fishes of the groups Elasmobranchii, Holocephali, Isospondyli, and Ostariophysi obtained by the United States Bureau of Fisheries steamer "Albatross" in 1907 to 1910 , chiefly in the Philippine Islands and adjacent seas. Bulletin of the United States National Museum, 13, 1-879.

Franchina, C. R., \& Hopkins, C. D. (1996). The dorsal filament of the weakly electric Apteronotidae (Gymnotiformes; Teleostei) is specialized for electroreception. Brain Behavior and Evolution, 47, 165-178. https://doi.org/10.1159/000113236

Franklin, O., Palmer, C., \& Dyke, G. (2014). Pectoral fin morphology of batoid fishes (Chondrichthyes: Batoidea): Explaining phylogenetic variation with geometric morphometrics. Journal of Morphology, 275, 1173-1186. https://doi.org/10.1002/jmor.20294

Freitas, R., Gómez-Skarmeta, J. L., \& Rodrigues, P. N. (2014). New frontiers in the evolution of fin development. Journal of Experimental Zoology Part B. Molecular and Developmental Evolution, 322B, 540552. https://doi.org/10.1002/jez.b.22563

Freitas, R., Zhang, G. J., \& Cohn, M. J. (2006). Evidence that mechanisms of fin development evolved in the midline of early vertebrates. Nature, 442, 1033-1037. https://doi.org/10.1038/nature04984

Freitas, R., Zhang, G. J., \& Cohn, M. J. (2007). Biphasic Hoxd gene expression in shark paired fins reveals an ancient origin of the distal limb domain. PLoS ONE, 2, e754. https://doi.org/10.1371/journ al.pone.0000754

Fricke, R., Eschmeyer, W. N., \& Fong, J. D. (2018). Species by family/subfamily in the catalog of fishes. Retrieved from http://researcharchive. calacademy.org/research/ichthyology/catalog/SpeciesByFamily.asp

Friedman, M. (2007). Styloichthys as the oldest coelacanth: Implications for early osteichthyan interrelationships. Journal of Systematic Palaeontology, 5, 289-343. https://doi.org/10.1017/s147720190 7002052

Friedman, M. (2010). Postcranial evolution in early lungfishes (Dipnoi: Sarcopterygii): New insights from Soederberghia groenlandica. In D. K. Elliott, J. G. Maisey, X. Yu, \& D. Miao (Eds.), Morphology, phylogeny and paleobiogeography of fossil fishes (pp. 299-324). München, Germany: Verlag Dr. Friedrich Pfeil.

Friedman, M., Johanson, Z., Harrington, R. C., Near, T. J., \& Graham, M. R. (2013). An early fossil remora (Echeneoidea) reveals the evolutionary assembly of the adhesion disc. Proceedings of the Royal Society B: Biological Sciences, 280, 20131200. https://doi.org/10.1098/ rspb.2013.1200

Froese, R., \& Pauly, D. (2016). Fishbase. Retrieved from www.fishbase.org

Fulcher, B. A., \& Motta, P. J. (2006). Suction disk performance of echeneid fishes. Canadian Journal of Zoology, 84, 42-50. https://doi. org/10.1139/z05-167
Furlong, R. F., \& Holland, P. W. H. (2002). Bayesian phylogenetic analysis supports monophyly of ambulacraria and of cyclostomes. Zoological Science, 19, 593-599. https://doi.org/10.2108/zsj.19.593

Gabbott, S. E., Aldridge, R. J., \& Theron, J. N. (1995). A giant conodont with preserved muscle tissue from the Upper Ordovician of South Africa. Nature, 374, 800-803. https://doi.org/10.1038/374800a0

Gagnier, P.-Y. (1989). The oldest vertebrate: A 470-million-year-old jawless fish, Sacabambaspis janvieri, from the Ordovician of Bolivia. National Geographic Research, 5, 250-253.

Gagnier, P.-Y. (1993a). Sacabambaspis janvieri, vertébré ordovicien de Bolivie. 1. Analyse morphologique. Annales de Paléontologie, 79, 19-51.

Gagnier, P.-Y. (1993b). Sacabambaspis janvieri, vertébré ordovicien de Bolivie. 2. Analyse phylogénétique. Annales de Paléontologie, 79, 119-166.

Gagnier, P.-Y., \& Blieck, A. (1992). On Sacabambaspis janvieri and the vertebrate diversity in Ordvician seas. In E. Mark-Kurik (Ed.), Fossil fishes as living animals (pp. 9-20). Tallinn, Estonia: Academy of Sciences of Estonia.

Gagnier, P.-Y., Blieck, A. R. M., \& Rodrigo, G. S. (1986). First Ordovician vertebrate from South America. Geobios, 19, 629-634. https://doi. org/10.1016/S0016-6995(86)80058-4

Gagnier, P.-Y., Hanke, G. F., \& Wilson, M. V. H. (1999). Tetanopsyrus lindoei gen. et sp. nov., an Early Devonian acanthodian from the Northwest Territories, Canada. Acta Geologica Polonica, 49, 81-96.

Gagnier, P.-Y., \& Wilson, M. V. H. (1996). Early Devonian acanthodians from northern Canada. Palaeontology, 39, 241-258.

Gai, Z. K., Donoghue, P. C. J., Zhu, M., Janvier, P., \& Stampanoni, M. (2011). Fossil jawless fish from China foreshadows early jawed vertebrate anatomy. Nature, 476, 324-327. https://doi.org/10.1038/natur e10276

Gai, Z.-K., Zhu, M., \& Zhao, W.-J. (2005). New material of eugaleaspids from the Silurian of Changxing, Zhejiang, China, with a discussion on the eugaleaspid phylogeny. Vertebrata Palasiatica, 43, 61-75.

Garman, S. (1913). The Plagiostomia (Sharks, skates, and rays). Memoirs of the Museum of Comparative Zoology at Harvard College, 36, 1-515.

Garstang, W. (1928). The morphology of the Tunicata, and its bearings on the phylogeny of the Chordata. Quarterly Journal of Microscopical Science, 72, 51-187.

Garstang, W. (1931). The phyletic classification of Teleostei. Proceedings of the Leeds Philosophical and Literary Society, Scientific Section, 2, 240-260.

Gayet, M., \& Meunier, F. J. (1991). Première découverte de Gymnotiformes fossiles (Pisces, Ostariophysi) dans le Myocène supérieur de Bolivie. Comptes Rendus de l'Académie des Sciences, Paris, Série, 2(313), 471-476.

Gayet, M., Meunier, F. J., \& Kirschbaum, F. (1994). Ellisella kirschbaumi Gayet and Meunier, 1991, Gymnotiforme fossile de Bolivie et ses relations phylogénétiques au sein des formes actuelles. Cybium, 18, 273-306.

Gegenbaur, C. (1876). Zur Morphologie der gliedmaassen der Wirbelthier. Morphologisches Jahrbuch, 2, 396-420.

Germain, D., Sanchez, S., Janvier, P., \& Tafforeau, P. (2014). The presumed hagfish Myxineidus gononorum from the Upper Carboniferous of Montceau-les-Mines (Saone-et-Loire, France): New data obtained by means of propagation phase contrast $\mathrm{X}$-ray synchrotron microtomography. Annales de Paléontologie, 100, 131-135. https://doi. org/10.1016/j.annpal.2013.12.003

Gess, R. W., \& Coates, M. I. (2015). Fossil juvenile coelacanths from the Devonian of South Africa shed light on the order of character acquisition in actinistians. Zoological Journal of the Linnean Society, 175, 360-383. https://doi.org/10.1111/zoj.12276

Gess, R. W., Coates, M. I., \& Rubidge, B. S. (2006). A lamprey from the Devonian period of South Africa. Nature, 443, 981-984. https://doi. org/10.1038/nature05150 
Gess, R. W., \& Trinajstic, K. M. (2017). New morphological information on, and species of placoderm fish Africanaspis (Arthrodira, Placodermi) from the Late Devonian of South Africa. PLoS ONE, 12, e0173169. https://doi.org/10.1371/journal.pone.0173169

Gibson-Brown, J. J., Agulnik, S. I., Chapman, D. L., Alexiou, M., Garvey, N., Silver, L. M., \& Papaioannou, V. E. (1996). Evidence of a role for $T$-box genes in the evolution of limb morphogenesis and the specification of forelimb/hindlimb identity. Mechanisms of Development, 56, 93-101. https://doi.org/10.1016/0925-4773(96)00514-x

Gilbert, S. F., Opitz, J. M., \& Raff, R. A. (1996). Resynthesizing evolutionary and developmental biology. Developmental Biology, 173, 357-372. https://doi.org/10.1006/dbio.1996.0032

Giles, S., Darras, L., Clement, G., Blieck, A., \& Friedman, M. (2015). An exceptionally preserved Late Devonian actinopterygian provides a new model for primitive cranial anatomy in ray-finned fishes. Proceedings of the Royal Society B: Biological Sciences, 282, 20151485. https://doi. org/10.1098/rspb.2015.1485

Giles, S., Friedman, M., \& Brazeau, M. D. (2015). Osteichthyan-like cranial conditions in an Early Devonian stem gnathostome. Nature, 520, 82-85. https://doi.org/10.1038/nature14065

Gill, T. (1890). On the relations of Cyclopteroidea. Proceedings of the United States National Museum, 13, 361-376. https://doi.org/10.5479/ si.00963801.13-834.361

Gillis, J. A., Dahn, R. D., \& Shubin, N. H. (2009). Shared developmental mechanisms pattern the vertebrate gill arch and paired fin skeletons. Proceedings of the National Academy of Sciences of the United States of America, 106, 5720-5724. https://doi.org/10.1073/pnas.08109 59106

Ginter, M., Hampe, O., \& Duffin, C. (2010). Volume 3D - Chondrichthyes - Paleozoic Elasmobranchii: Teeth. München, Germany: Verlag Dr. Friedrich Pfeil.

Ginter, M., \& Turner, S. (2010). The middle Paleozoic selachian genus Thrinacodus. Journal of Vertebrate Paleontology, 30, 1666-1672. https ://doi.org/10.1080/02724634.2010.520785

Goodrich, E. S. (1909). A treatise on zoology, part IX: Vertebrata Craniata (First Fascicle: Cyclostomes and fishes). London, UK: Adam and Charles Black.

Goodrich, E. S. (1930). Studies on the structure and development of vertebrates. London, UK: McMillan and Co.

Goodsir, J. (1844). On the anatomy of Amphioxus lanceolatus; lancelet, Yarrell. Transactions of the Royal Society of Edinburgh, 15, 247-263. https://doi.org/10.1017/S0080456800029938

Goodyear, R. H., \& Gibbs, R. H. (1986). Family No. 71: Malacosteidae. In M. M. Smith, \& P. C. Heemstra (Eds.), Smith's sea fishes (pp. 235-236). Berlin, Germany: Springer.

Gormon, J. R. (1986). Family No. 60: Plotosidae. In M. M. Smith, \& P. C. Heemstra (Eds.), Smith's sea fishes (pp. 213-213). Berlin, Germany: Springer.

Goüan, A. (1770). Histoire des poissons. Strasbourg, France: Amand König.

Goujet, D. (1984). Placoderm interrelationships: A new interpretation, with a short review of placoderm classification. Proceedings of the Linnean Society of New South Wales, 107, 211-243.

Goujet, D. (2001). Placoderms and basal gnathostome apomorphies. In P. E. Ahlberg (Ed.), Major events in early vertebrate evolution: Palaeontology, phylogeny, genetics and development (pp. 209-222). London, UK: Taylor \& Francis.

Gray, J. E. (1831). XIII. Description of twelve new genera of fish, discovered by Gen. Hardwicke, in India, the greater part in the British Museum. The Zoological Miscellany, 1, 7-9.

Greenwood, P. H., Rosen, D. E., Weitzman, S. H., \& Myers, G. S. (1966). Phyletic studies of teleostean fishes, with a provisional classification of living forms. Bulletin of the American Museum of Natural History, 131, 339-456.

Gregory, W. K., \& Raven, H. C. (1941). Studies on the origin and early evolution of paired fins and limbs. 1. Paired fins and girdles in ostracoderms, placoderms and other primitive fishes. Annals of the New York Academy of Science, 42, 275-291. https://doi. org/10.1111/j.1749-6632.1942.tb57058.x

Grogan, E. D., \& Lund, R. (2000). Debeerius ellefseni (fam. nov., gen. nov., spec. nov.), an autodiastylic chondrichthyan from the Mississippian Bear Gulch Limestone of Montana (USA), the relationships of the Chondrichthyes, and comments on gnathostome evolution. Journal of Morphology, 243, 219-245. https://doi.org/10.1002/(sici)10974687(200003)243:3<219:aid-jmor1>3.3.co;2-t

Grogan, E. D., \& Lund, R. (2004). The origin and relationships of early Chondrichthyes. In J. C. Carrier, J. A. Musick, \& M. R. Heithaus (Eds.), Biology of sharks and their relatives (pp. 3-31). Boca Raton, FL: CRC Press.

Grogan, E. D., \& Lund, R. (2008). A basal elasmobranch, Thrinacoselache gracia n. gen. \& sp., (Thrinacodontidae, new family) from the Bear Gulch Limestone, Serpukhovian of Montana, USA. Journal of Vertebrate Paleontology, 28, 970-988. https://doi. org/10.1671/0272-4634-28.4.970

Grogan, E. D., \& Lund, R. (2009). Two new iniopterygians (Chondrichthyes) from the Mississippian (Serpukhovian) Bear Gulch Limestone of Montana with evidence of a new form of chondrichthyan neurocranium. Acta Zoologica, 90, 134-151. https://doi. org/10.1111/j.1463-6395.2008.00371.x

Grogan, E. D., Lund, R., \& Greenfest-Allen, E. (2012). The origin and relationships of early chondrichthyans. In J. C. Carrier, J. A. Musick, \& M. R. Heithaus (Eds.), Biology of sharks and their relatives (2nd ed., pp. 3-29). Boca Raton, FL: CRC Press.

Grünbaum, T., Cloutier, R., \& Vincent, B. (2012). Dynamic skeletogenesis in fishes: Insight of exercise training on developmental plasticity. Developmental Dynamics, 241, 1507-1524. https://doi.org/10.1002/ dvdy.23837

Günther, A. C. L. G. (1880). An introduction to the study of fishes. Edinburgh, Scotland: Adam and Charles Black.

Hadzhiev, Y., Lele, Z., Schindler, S., Wilson, S. W., Ahlberg, P., Strahle, U., \& Muller, F. (2007). Hedgehog signaling patterns the outgrowth of unpaired skeletal appendages in zebrafish. BMC Developmental Biology, 7, 75. https://doi.org/10.1186/1471-213x-7-75

Hairapetian, V., Valiukevičius, J., \& Burrow, C. J. (2006). Early Frasnian acanthodians from central Iran. Acta Palaeontologica Polonica, 51, 499-520.

Hall, B. K. (1994a). Homology: The hierachical basis of comparative biology. San Diego, CA: Academic Press.

Hall, B. K. (1994b). Introduction. In B. K. Hall (Ed.), Homology: The hierachical basis of comparative biology (pp. 1-19). San Diego, CA: Academic Press.

Hall, B. K. (2010). Charles Darwin, embryology, evolution and skeletal plasticity. Journal of Applied Ichthyology, 26, 148-151. https://doi. org/10.1111/j.1439-0426.2010.01394.x

Halstead, B. W. (1978). Chapter XVIII - Vertebrates. Class Chondrichthyes. In B. W. Halstead, Poisonous and venomous marine animals of the world (pp. 605-678). Princeton, NJ: Darwin Press.

Halstead, B. W., Ocampo, R. R., \& Modglin, F. R. (1955). A study on the comparative anatomy of the venom apparatus of certain North American stingrays. Journal of Morphology, 97, 1-21. https://doi. org/10.1002/jmor.1050970102

Halstead, L. B. (1973). The heterostracan fishes. Biological Reviews, 48 , 279-332. https://doi.org/10.1111/j.1469-185X.1973.tb01005.x

Halstead, L. B. (1982). Evolutionary trends and the phylogeny of the Agnatha. In K. A. Joysey, \& A. E. Friday (Eds.), Problems of phylogenetic reconstruction (pp. 159-196). London, UK: Academic Press.

Halstead, L. B., \& Turner, S. (1973). Silurian and Devonian ostracoderms. In A. Hallam (Ed.), Atlas of Palaeobiogeography (pp. 67-79). Amsterdam, The Netherlands: Elsevier Scientific Publishing Company.

Hanke, G. F. (2002). Paucicanthus vanelsti gen. et sp. nov., an Early Devonian (Lochkovian) acanthodian that lacks paired fin-spines. 
Canadian Journal of Earth Sciences, 39, 1071-1083. https://doi. org/10.1139/e02-023

Hanke, G. F. (2008). Promesocanthus eppleri n. gen., n. sp., a mesacanthid (Acanthodii, Acanthodiformes) from the Lower Devonian of northern Canada. Geodiversitas, 30, 287-302.

Hanke, G. F., \& Davis, S. P. (2008). Redescription of the acanthodian Gladiobranchus probaton Bernacsek \& Dineley, 1977, and comments on diplacanthid relationships. Geodiversitas, 30, 303-330.

Hanke, G. F., \& Davis, S. P. (2012). A re-examination of Lupopsyrus pygmaeus Bernacsek \& Dineley, 1977 (Pisces, Acanthodii). Geodiversitas, 34, 469-487. https://doi.org/10.5252/g2012n3a1

Hanke, G. F., Davis, S. P., \& Wilson, M. V. H. (2001). New species of the acanthodian genus Tetanopsyrus from Northern Canada, and comments on related taxa. Journal of Vertebrate Paleontology, 21, 740753. https://doi.org/10.1671/0272-4634(2001)021[0740:nsota g]2.0.co;2

Hanke, G. F., \& Wilson, M. V. H. (2002). New teleostome fishes and acanthodian systematics. Journal of Vertebrate Paleontology, 22, 187-214.

Hanke, G. F., \& Wilson, M. V. H. (2004). New teleostome fishes and acanthodian systematics. In G. Arratia, M. V. H. Wilson, \& R. Cloutier (Eds.), Recent advances in the origin and early radiation of vertebrates (pp. 189-216). München, Germany: Verlag Dr. Friedrich Pfeil.

Hanke, G. F., \& Wilson, M. V. H. (2006). Anatomy of the Early Devonian acanthodian Brochoadmones milesi based on nearly complete body fossils, with comments on the evolution and development of paired fins. Journal of Vertebrate Paleontology, 26, 526-537. https://doi. org/10.1671/0272-4634(2006)26[526:aoteda]2.0.co;2

Hanke, G. F., \& Wilson, M. V. H. (2010). The putative stem-group chondrichthyans Kathemacanthus and Seretolepis from the Lower Devonian MOTH locality, Mackenzie Mountains, Canada. In D. K. Elliott, J. G. Maisey, X. Yu, \& D. Miao (Eds.), Morphology, phylogeny and paleobiogeography of fossil fishes (pp. 159-182). München, Germany: Verlag Dr. Friedrich Pfeil.

Hardisty, M. W. (1979). Biology of the cyclostomes. London, UK: Chapman and Hall.

Hardisty, M. W., \& Potter, I. C. (1971). The general biology of adult lampreys. In M. W. Hardisty, \& I. C. Potter (Eds.), The Biology of Lampreys (Vol. 1, pp. 127-206). London, UK: Academic Press.

Hedges, S. B. (2001). Molecular evidence for the early history of living vertebrates. In P. E. Ahlberg (Ed.), Major events in early vertebrate evolution: Palaeontology, phylogeny, genetics and development ( $p$. 119-134). London, UK: Taylor \& Francis.

Heidtke, U. (1990). Studien über Acanthodes (Pisces: Acanthodii) aus dem saar-pfälzischen Rotliegend (?Ober-Karbon-Unter-Perm, SW-Deutschland). In U. Heidtke (Ed.), New Research on PermoCarboniferous Fauna. Pollichia-Buch Nr. 19 (pp. 1-86). Bad Dürkheim, Germany: Pfalzmuseum für Naturkunde.

Heimberg, A. M., Cowper-Sallari, R., Semon, M., Donoghue, P. C. J., \& Peterson, K. J. (2010). microRNAs reveal the interrelationships of hagfish, lampreys, and gnathostomes and the nature of the ancestral vertebrate. Proceedings of the National Academy of Sciences of the United States of America, 107, 19379-19383. https://doi.org/10.1073/ pnas.1010350107

Heintz, A. (1931). Revision of the structure of Coccosteus decipiens Ag. Norsk Geologisk Tidsskrift, 12, 291-313.

Heintz, A. (1938). Notes on Arthrodira. Norsk Geografisk Tidsskrift, 18 1-27.

Heintz, A. (1939). Cephalaspids from the Downtonian of Norway. NorskeVidenskapsakademiens Skrifter (Skrifter utgitt av Det Norske Videnskaps-Akademi i. Oslo): Matematiske-naturvetenskapslige Klasse, 5, 1-119.

Heintz, A. (1967). A new tremataspidid from Ringerike, South Norway. Journal of the Linnean Society of London, Zoology, 47, 55-68. https:// doi.org/10.1111/j.1096-3642.1967.tb01395.x
Hennig, W. (1969). Die Stammesgeschichte der Insekten. Frankfurt am Main, Germany: Waldemar Kramer.

Herdman, W. A. (1904). Ascidians and amphioxus. In S. F. Harmer, \& A. E. Shipley (Eds.), The Cambridge Natural History (Vol. VII, pp. 35-138). London, UK: McMillan and Co. Limited.

Hirasawa, T., Oisi, Y., \& Kuratani, S. (2016). Palaeospondylus as a primitive hagfish. Zoological Letters, 2, 20. https://doi.org/10.1186/ s40851-016-0057-0

Holland, N. D., \& Chen, J. Y. (2001). Origin and early evolution of the vertebrates: New insights from advances in molecular biology, anatomy, and palaeontology. BioEssays, 23, 142-151. https ://doi.org/10.1002/1521-1878(200102)23:2<142:aid-bies1 021>3.0.co;2-5

Holland, N. D., \& Holland, L. Z. (1991). The histochemistry and fine structure of the nutritional reserves in the fin rays of a lancelet, Branchiostoma lanceolatum (Cephalochordata, Acrania). Acta Zoologica, 72, 203-207. https://doi.org/10.1111/j.1463-6395.1991. tb01197.x

Hopson, J. A. (1974). The functional significance of the hypocercal tail and lateral fin fold of anaspid ostracoderms. Fieldiana, Geology, 33, 83-93. https://doi.org/10.5962/bhl.title.5175

Hou, X. G., Ramskold, L., \& Bergstrom, J. (1991). Composition and preservation of the Chengjiang fauna - A Lower Cambrian soft-bodied biota. Zoologica Scripta, 20, 395-411. https://doi. org/10.1111/j.1463-6409.1991.tb00303.x

Howell, A. B. (1933). Homology of the paired fins in fishes. Journal of Morphology, 54, 451-457. https://doi.org/10.1002/jmor.10505 40303

Hubbs, C. L. (1922). A list of the lancelets of the world with diagnoses of five new species of Branchiostoma. Occasional Papers of the Museum of Zoology, University of Michigan, 105, 1-16.

Hulley, P. A. (1986). Family No. 70: Idiacanthidae. In M. M. Smith, \& P. C. Heemstra (Eds.), Smith's sea fishes (pp. 234-235). Berlin, Germany: Springer.

Hume, J. B., Bean, C. W., \& Adams, C. E. (2014). Morphological abnormalities in a population of Lampetra planeri, with a short review of petromyzontid teratologies. Journal of Fish Biology, 84, 1614-1619. https://doi.org/10.1111/jfb.12369

Huxley, T. H. (1871). A manual of the anatomy of vertebrated animals. London, UK: J. \& A. Churchill.

Inoue, J. G., Miya, M., Lam, K., Tay, B. H., Danks, J. A., Bell, J., ...Venkatesh, B. (2010). Evolutionary origin and phylogeny of the modern holocephalans (Chondrichthyes: Chimaeriformes): A mitogenomic perspective. Molecular Biology and Evolution, 27, 2576-2586. https://doi. org $/ 10.1093 / \mathrm{molbev} / \mathrm{msq} 147$

Insom, E., Pucci, A., \& Simonetta, A. M. (1995). Cambrian Protochordata, their origin and significance. Bollettino Di Zoologia, 62, 243-252. https://doi.org/10.1080/11250009509356072

Isaac, A., Rodriguez-Esteban, C., Ryan, A., Altabef, M., Tsukui, T., Patel, K., ...lzpisua-Belmonte, J. C. (1998). Tbx genes and limb identity in chick embryo development. Development, 125, 1867-1875.

Janvier, P. (1978). Les nageoires paires des ostéostracés et la position systématique des céphalaspidomorphes. Annales de Paléontologie (Vertébrés), 64, 113-142.

Janvier, P. (1981a). Norselaspis glacialis n.g., n.sp. et les relations phylogénétiques entre les Kieraspidiens (Osteostraci) du Dévonien inférieur du Spitsberg. Palaeovertebrata, 11, 19-131.

Janvier, P. (1981b). The phylogeny of the Craniata, with particular reference to the significance of fossil "agnathans". Journal of Vertebrate Paleontology, 1, 121-159. https://doi.org/10.1080/02724 634.1981.10011886

Janvier, P. (1984). The relationships of the Osteostraci and Galeaspida. Journal of Vertebrate Paleontology, 4, 344-358. https://doi. org/10.1080/02724634.1984.10012014 
Janvier, P. (1985a). Environmental framework of the diversification of the Osteostraci during the Silurian and Devonian. Philosophical Transactions of the Royal Society of London Series B. Biological Sciences, 309, 259-272. https://doi.org/10.1098/rstb.1985.0086

Janvier, P. (1985b). Les thyestidiens (Osteostraci) du Silurien de Saaremaa (Estonie). Deuxième partie: Analyse phylogénétique, répartition stratigraphique, remarques sur les genres Auchenaspis, Timanaspis, Tyriaspis, Didymaspis. Sclerodus et Tannuaspis. Annales de Paléontologie, 71, 187-216.

Janvier, P. (1985c). Preliminary description of Lower Devonian Osteostraci from Podolia (Ukrainian U.S.S.R.). Bulletin of the British Museum (Natural History) - Geology, 38, 309-334.

Janvier, P. (1987). The paired fins of anaspids: One more hypothesis about their function. Journal of Paleontology, 61, 850-853. https:// doi.org/10.1017/S0022336000029188

Janvier, P. (1996a). The dawn of the vertebrates: Characters versus common ascent in the rise of current vertebrate phylogenies. Palaeontology, 39, 259-287.

Janvier, P. (1996b). Early vertebrates. Oxford, UK: Oxford University Press.

Janvier, P. (1996c). The Miguasha "Anaspida". In H.-P. Schultze, \& R. Cloutier (Eds.), Devonian fishes and plants of Miguasha, Quebec, Canada (pp. 134-140). München, Germany: Verlag Dr. Friedrich Pfeil.

Janvier, P. (2007). Homologies and evolutionary transitions in early vertebrate history. In J. S. Anderson, \& H. D. Sues (Eds.), Major transitions in vertebrate evolution (pp. 57-121). Bloomington, IN: Indiana University Press.

Janvier, P. (2008). Early jawless vertebrates and cyclostome origins. Zoological Science, 25, 1045-1056. https://doi.org/10.2108/ zsj.25.1045

Janvier, P., \& Arsenault, M. (1996). Osteostraci. In H.-P. Schultze, \& R. Cloutier (Eds.), Devonian fishes and plants of Miguasha, Quebec, Canada (pp. 123-133). München, Germany: Verlag Dr. Friedrich Pfeil.

Janvier, P., \& Arsenault, M. (2007). The anatomy of Euphanerops longaevus Woodward, 1900, an anaspid-like jawless vertebrate from the Upper Devonian of Miguasha, Quebec, Canada. Geodiversitas, 29, 143-216.

Janvier, P., Arsenault, M., \& Desbiens, S. (2004). Calcified cartilage in the paired fins of the osteostracan Escuminaspis laticeps (Traquair 1880), from the Late Devonian of Miguasha (Quebec, Canada), with a consideration of the early evolution of the pectoral fin endoskeleton in vertebrates. Journal of Vertebrate Paleontology, 24, 773-779. https:// doi.org/10.1671/0272-4634(2004)024[0773:ccitpf]2.0.co;2

Janvier, P., \& Blieck, A. (1979). New data on the internal anatomy of the Heterostraci (Agnatha), with general remarks on the phylog eny of the Craniota. Zoologica Scripta, 8, 287-296. https://doi. org/10.1111/j.1463-6409.1979.tb00640.x

Janvier, P., Desbiens, S., Willett, J. A., \& Arsenault, M. (2006). Lampreylike gills in a gnathostome-related Devonian jawless vertebrate. Nature, 440, 1183-1185. https://doi.org/10.1038/nature04471

Janvier, P., \& Lund, R. (1983). Hardistiella montanensis n. gen. et sp. (Petromyzontida) from the Lower Carboniferous of Montana, with remarks on the affinities of the lampreys. Journal of Vertebrate Paleontology, 2, 407-413. https://doi.org/10.1080/02724 634.1983.10011943

Janvier, P., Lund, R., \& Grogan, E. D. (2004). Further consideration of the earliest known lamprey, Hardistiella montanensis Janvier and Lund, 1983, from the Carboniferous of Bear Gulch, Montana, USA. Journal of Vertebrate Paleontology, 24, 742-743. https://doi. org/10.1671/0272-4634(2004)024[0742:fcotek]2.0.co;2

Jarvik, E. (1959). Dermal fin-rays and Holmgren's principle of delamination. Kunglica Svenska Vetenskapsakademiens Handlingar, 6, 3-51.

Jarvik, E. (1960). Théories de l'évolution des vertébrés reconsidérées à la lumière des récentes découvertes sur les vertébrés inférieurs. Paris, France: Masson et Cie, Libraires de L'Académie de Médicine.
Jarvik, E. (1980). Basic structure and evolution of vertebrates, Vol. 2 London, UK: Academic Press.

Jayaram, K. C. (1981). The freshwater fishes of India, Pakistan, Bangladesh, Burma and Sri Lanka. Calcutta, India: Zoological Survey of India.

Jayaram, K. C. (1982). Aid to the identification of the siluroid fishes of India, Burma, Sri Lanka, Pakistan and Bangladesh. 5. Ariidae and Plotosidae. Records of the Zoological Survey of India. Miscellaneous Publications, Occasional Paper No 37, 1-41.

Jefferies, R. P. S. (1973). The Ordovician fossil Lagynocystis pyramidalis (Barrande) and the ancestry of Amphioxus. Philosophical Transactions of the Royal Society B. Biological Sciences, 265, 409-469. https://doi. org/10.1098/rstb.1973.0032

Jefferies, R. P. S. (1979). The origin of the chordates - A methodological essay. In M. R. House (Ed.), The origin of major invertebrate groups (pp. 443-477). London, UK: Academic Press.

Jefferies, R. P. S. (1986). The ancestry of the vertebrates. Cambridge, UK: Cambridge University Press.

Jefferies, R. P. S., \& Lewis, D. N. (1978). The English Silurian fossil Placocystites forbesianus and the ancestry of the vertebrates. Philosophical Transactions of the Royal Society B. Biological Sciences, 282, 205-323. https://doi.org/10.1098/rstb.1978.0013

Jessen, H. L. (1966). Die Crossopterygier des Oberen Plattenkalkes (Devon) der Bergisch-Gladbach-Paffrather Mulde (Rheinisches Schiefergebirge) unter Berücksichtigung von amerikanischem und europäischem Onychodus-material. Arkiv för Zoologi, 18, 305-389.

Jessen, H. L. (1973). Weitere Fischreste aus dem Oberen Plattenkalk der Bergische-Gladbach Paffrather Mulde (Oberdevon, Rheinisches Schiefergebirge). Palaeontographica Abteilung A: Paläozoologie Stratigraphie, A143, 159-187.

Johanson, Z. (1997). New Remigolepis (Placodermi; Antiarchi) from Canowindra, New South Wales, Australia. Geological Magazine, 134 813-846. https://doi.org/10.1017/s0016756897007838

Johanson, Z. (2002). Vascularization of the osteostracan and antiarch (Placodermi) pectoral fin: Similarities, and implications for placoderm relationships. Lethaia, 35, 169-186. https://doi.org/10.1080/00241 1602320184024

Johanson, Z. (2010). Evolution of paired fins and the lateral somitic frontier. Journal of Experimental Zoology Part B: Molecular and Developmental Evolution, 314B, 347-352. https://doi.org/10.1002/ jez.b.21343

Johanson, Z., Ericsson, R., Long, J., Evans, F., \& Joss, J. (2009). Development of the axial skeleton and median fin in the Australian lungfish, Neoceratodus forsteri. The Open Zoology Journal, 2, 91-101. https://doi.org/10.2174/1874336600902010091

Johanson, Z., Long, J. A., Talent, J. A., Janvier, P., \& Warren, J. W. (2006). Oldest coelacanth, from the Early Devonian of Australia. Biology Letters, 2, 443-446. https://doi.org/10.1098/rsbl.2006.0470

Johansson, P. K. E., Douglass, T. G., \& Lowe, C. G. (2004). Caudal spine replacement and histogenesis in the round stingray, Urobatis halleri. Bulletin of the Southern California Academy of Science, 103, 115-124.

Johnson, G. D., \& Patterson, C. (1993). Percomorph phylogeny: A survey of acanthomorphs and a new proposal. Bulletin of Marine Science, 52, 554-626.

Jordan, D. S., \& Evermann, B. W. (1896). The fishes of North and Middle America: Descriptive catalogue of the species of fish-like vertebrates found in the waters of North America, north of the Isthmus of Panama. Part I. Bulletin of the United States National Museum, 47, 1-1240. https://doi.org/10.5962/bhl.title.46755

Jordan, D. S., \& Gilbert, C. H. (1882). Synopsis of the fishes of North America. Bulletin of the United States National Museum, 16, 1-1018. https://doi.org/10.5479/si.03629236.16.i

Jordan, D. S., \& Snyder, J. O. (1901). A review of the lancelets, hagfishes, and lampreys of Japan, with description of two new species. Proceedings of the United States National Museum, 23, 725-734. https ://doi.org/10.5479/si.00963801.23-1233.725 
Kaup, J. J. (1856). Catalogue of apodal fish, in the collection of the British Museum. London, UK: British Museum of Natural History.

Kawaguchi, K., \& Moser, H. G. (1984). Stomiatoidea: Development. In H G. Moser, W. J. Richards, D. M. Cohen, M. P. Fahay, A. W. Kendall, \& S. L. Richardson (Eds.), Ontogeny and systematics of fishes. Based on an international symposium dedicated to the memory of Elbert Halvor Ahlstrom (pp. 169-181). Lawrence, KS: The American Society of Ichthyologists and Herpetologists.

Keating, J. N., \& Donoghue, P. C. J. (2016). Histology and affinity of anaspids, and the early evolution of the vertebrate dermal skeleton. Proceedings of the Royal Society B: Biological Sciences, 283, 20152917. https://doi.org/10.1098/rspb.2015.2917

Keating, J. N., Sansom, R. S., \& Purnell, M. A. (2012). A new osteostracan fauna from the Devonian of the Welsh Borderlands and observations on the taxonomy and growth of Osteostraci. Journal of Vertebrate Paleontology, 32, 1002-1017. https://doi.org/10.1080/02724 634.2012.693555

Kemp, N. E. (1999). Integumentary system and teeth. In W. C. Hamlett (Ed.), Sharks, skates and rays: The biology of Elasmobranch fishes (pp. 43-68). Baltimore, MD: The Johns Hopkins University Press.

Kenaley, C. P., \& Hartel, K. E. (2005). A revision of Atlantic species of Photostomias (Teleostei: Stomiidae: Malacosteinae), with a description of a new species. Ichthyological Research, 52, 251-263. https:// doi.org/10.1007/s10228-005-0281-7

Khonsari, R. H., Li, B., Vernier, P., Northcutt, R. G., \& Janvier, P. (2009). Agnathan brain anatomy and craniate phylogeny. Acta Zoologica, 90, 52-68. https://doi.org/10.1111/j.1463-6395.2008.00388.x

Kiaer, J. (1911). A new Downtonian fauna in the sandstone series of the Kristiania area: A preliminary report. Videnskapsselskapets Skrifter. I. Matematiske-Naturvidenskaplige Klasse, 7, 1-22.

Kiaer, J. (1924). The Downtonian fauna of Norway. I. Anaspida, with a geological introduction. Videnskapsselskapets Skrifter. I. MatematiskeNaturvidenskaplige Klasse, 6, 1-139.

Kirkaldy, J. W. (1895). A revision of the genera and species of the Branchiostomidae. Quarterly Journal of Microscopical Science, 37, 303-323.

Klimley, A. P. (2013). The biology of sharks and rays. Chicago, IL: The University of Chicago Press.

Kott, E., Renaud, C. B., \& Vladykov, V. D. (1988). The urogenital papilla in the holarctic lamprey (Petromyzontidae). Environmental Biology of Fishes, 23, 37-43. https://doi.org/10.1007/BF00000736

Kowalevsky, A. O. (1866). Entwickelungsgeschichte der einfachen Ascidien. Mémoires de l'Académie impériale des. Sciences de St.Pétersbourg: Viième Série, 10, 1-19.

Kuo, C.-H., Huang, K.-F., \& Mok, H.-K. (1994). Hagfishes of Taiwan (I): A taxonomic revision with description of four new Paramyxine species. Zoological Studies, 33, 126-139.

Lacépède, B. G. E. (1798). Histoire naturelle des poissons, Tome premier. Paris, France: Plassan.

Lacépède, B. G. E., Cuvier, G., \& Desmarest, M.-A.-G. (1853). Histoire naturelle de Lacépède, Tome premier, comprenant les cétacées, les quadrupèdes ovipares, les serpents et les poissons. Bruxelles, Belgium: Adolphe Deros et Comp.

Lankester, E. R. (1870). Part I. - The Cephalaspidae. In J. Powrie, \& E. R. Lankester (Eds.), A monograph of the fishes of the Old Red Sandstone of Britain (pp. 1-62). London, UK: Palaeontographical Society.

Lankester, E. R. (1875). On some new points in the structure of Amphioxus, and their bearing on the morphology of Vertebrata. Quarterly Journal of Microscopical Science, 15, 257-267.

Lankester, E. R. (1889). Contributions to the knowledge of Amphioxus lanceolatus, Yarrell. Quarterly Journal of Microscopical Science, 29, 365-408.

Larouche, O., Zelditch, M. L., \& Cloutier, R. (2017). Fin modules: An evolutionary perspective on appendage disparity in basal vertebrates. BMC Biology, 15, 32. https://doi.org/10.1186/s12915-017-0370-x
Larouche, O., Zelditch, M. L., \& Cloutier, R. (2018). Modularity promotes morphological divergence in ray-finned fishes. Scientific Reports, 8 , 7278. https://doi.org/10.1038/s41598-018-25715-y

Lauder, G. V., \& Drucker, E. G. (2004). Morphology and experimental hydrodynamics of fish fin control surfaces. IEEE Journal of Oceanic Engineering, 29, 556-571. https://doi.org/10.1109/koe.833219

Lauder, G. V., \& Liem, K. F. (1983). The evolution and interrelationships of the actinopterygian fishes. Bulletin of the Museum of Comparative Zoology, 150, 95-197.

Lavoué, S., Miya, M., Arnegard, M. E., Sullivan, J. P., Hopkins, C. D., \& Nishida, M. (2012). Comparable ages for the independent origins of electrogenesis in African and South American weakly electric fishes. PLoS ONE, 7, e36287. https://doi.org/10.1371/journal. pone. 0036287

Lehtola, K. A. (1983). Articulated Ordovician fish from Cañon City, Colorado. Journal of Paleontology, 57, 605-607.

Letelier, J., de la Calle-Mustienes, E., Pieretti, J., Naranjo, S., Maeso, I., Nakamura, T., ...Gómez-Skarmeta, J. L. (2018). A conserved Shh cis-regulatory module highlights a common developmental origin of unpaired and paired fins. Nature Genetics, 50, 504-509. https://doi. org/10.1038/s41588-018-0080-5

Lindsey, C. C. (1978). Form, function, and locomotory habits in fish. In W. S. Hoar, \& D. J. Randall (Eds.), Fish physiology. Volume VII. Locomotion (pp. 1-100). New York, NY: Academic Press.

Liu, Y. (1975). Lower Devonian agnathans of Yunnan and Sichuan. Vertebrata Palasiatica, 13, 202-216.

Long, J. A., \& Clement, A. M. (2009). The postcranial anatomy of two Middle Devonian lungfishes (Osteichthyes, Dipnoi) from Mt. Howitt, Victoria, Australia. Memoirs of Museum Victoria, 66, 189-202. https:// doi.org/10.24199/j.mmv.2009.66.17

Long, J. A., Mark-Kurik, E., Johanson, Z., Lee, M. S. Y., Young, G. C., Min, Z., ...Trinajstic, K. (2015). Copulation in antiarch placoderms and the origin of gnathostome internal fertilization. Nature, 517, 196-199. https://doi.org/10.1038/nature13825

Løvtrup, S. (1977). The phylogeny of vertebrata. London, UK: John Wiley $\&$ Sons Ltd.

Lowe, C. G., Moss, G. J., Hoisington, G.IV, Vaudo, J. J., Cartamil, D. P., Marcotte, M. M., \& Papastamatiou, Y. P. (2007). Caudal spine shedding periodicity and site fidelity of round stingrays, Urobatis halleri (Cooper), at Seal Beach, California: Implications for stingray-related injury management. Bulletin of the Southern California Academy of Sciences, 106, 16-26. https://doi.org/10.3160/00383872(2007)106[16:CSSPAS]2.0.CO;2

Lu, J., Giles, S., Friedman, M., den Blaauwen, J. L., \& Zhu, M. (2016). The oldest actinopterygian highlights the cryptic early history of the hyperdiverse ray-finned fishes. Current Biology, 26, 1602-1608. https:// doi.org/10.1016/j.cub.2016.04.045

Lu, J., \& Zhu, M. (2010). An onychodont fish (Osteichthyes, Sarcopterygii) from the Early Devonian of China, and the evolution of the Onychodontiformes. Proceedings of the Royal Society B: Biological Sciences, 277, 293-299. https://doi.org/10.1098/rspb.2009.0708

Lu, J., Zhu, M., Ahlberg, P. E., Qiao, T., Zhu, Y., Zhao, W., \& Jia, L. (2016). A Devonian predatory fish provides insights into the early evolution of modern sarcopterygians. Science Advances, 2, e1600154. https://doi. org/10.1126/sciadv.1600154

Lund, R. (1985). Stethacanthid elasmobranch remains from the Bear Gulch Limestone (Namurian E2b) of Montana. American Museum Novitates, 2828, 1-24.

Lund, R., \& Grogan, E. D. (1997). Relationships of the Chimaeriformes and the basal radiation of the Chondrichthyes. Reviews in Fish Biology and Fisheries, 7, 65-123. https://doi.org/10.1023/a:1018471324332

Lund, R., \& Grogan, E. D. (2004). Five new euchondrocephalan Chondrichthyes from the Bear Gulch Limestone (Serpukhovian, Namurian E2b) of Montana, USA. In G. Arratia, M. V. H. Wilson, \& R. Cloutier (Eds.), Recent advances in the origin and early radiation of 
vertebrates (pp. 505-531). München, Germany: Verlag Dr. Friedrich Pfeil.

Lund, R., Grogan, E. D., \& Fath, M. (2014). On the relationships of the Petalodontiformes (Chondrichthyes). Paleontological Journal, 48, 1015-1029. https://doi.org/10.1134/s0031030114090081

Luo, H. L., Hu, S. X., \& Chen, L. Z. (2001). New Early Cambrian chordates from Haikou, Kunming. Acta Geologica Sinica, 75, 345-348. https:// doi.org/10.1111/j.1755-6724.2001.tb00051.x

Mabee, P. M. (2000). Developmental data and phylogenetic systematics: Evolution of the vertebrate limb. American Zoologist, 40, 789800. https://doi.org/10.1668/0003-1569(2000)040[0789:ddaps e]2.0.co;2

Mabee, P. M., Crotwell, P. L., Bird, N. C., \& Burke, A. C. (2002). Evolution of median fin modules in the axial skeleton of fishes. Journal of Experimental Zoology (Molecular and Developmental Evolution), 294, 77-90. https://doi.org/10.1002/jez.10076

Maisey, J. G. (1984a). Chondrichthyan phylogeny: A look at the evidence. Journal of Vertebrate Paleontology, 4, 359-371. https://doi. org/10.1080/02724634.1984.10012015

Maisey, J. G. (1984b). Higher elasmobranch phylogeny and biostratigraphy. Zoological Journal of the Linnean Society, 82, 33-54. https://doi. org/10.1111/j.1096-3642.1984.tb00534.x

Maisey, J. G. (1986). Heads and tails: A chordate phylogeny. Cladistics, 2, 201-256. https://doi.org/10.1111/j.1096-0031.1986.tb00462.x

Maisey, J. G. (2009). The spine-brush complex in Symmoriiform sharks (Chondrichthyes; Symmoriiformes), with comments on dorsal fin modularity. Journal of Vertebrate Paleontology, 29, 14-24. https://doi. org/10.1671/039.029.0130

Maisey, J. G. (2012). What is an elasmobranch'? The impact of palaeontology in understanding elasmobranch phylogeny and evolution. Journal of Fish Biology, 80, 918-951. https://doi. org/10.1111/j.1095-8649.2012.03245.x

Maisey, J. G., Miller, R., Pradel, A., Denton, J. S. S., Bronson, A., \& Janvier, P. (2017). Pectoral morphology in Doliodus: Bridging the 'acanthodian'-chondrichthyan divide. American Museum Novitates, 3875, 1-15. https://doi.org/10.1206/3875.1

Maisey, J. G., Miller, R., \& Turner, S. (2009). The braincase of the chondrichthyan Doliodus from the Lower Devonian Campbellton Formation of New Brunswick, Canada. Acta Zoologica, 90, 109-122. https://doi.org/10.1111/j.1463-6395.2008.00330.x

Maisey, J. G., Turner, S., Naylor, G. J. P., \& Miller, R. F. (2014). Dental patterning in the earliest sharks: Implications for tooth evolution. Journal of Morphology, 275, 586-596. https://doi.org/10.1002/jmor.20242

Malashichev, Y., Borkhvardt, V., Christ, B., \& Scaal, M. (2005). Differential regulation of avian pelvic girdle development by the limb field ectoderm. Anatomy and Embryology, 210, 187-197. https://doi. org/10.1007/s00429-005-0014-8

Malashichev, Y., Christ, B., \& Prols, F. (2008). Avian pelvis originates from lateral plate mesoderm and its development requires signals from both ectoderm and paraxial mesoderm. Cell and Tissue Research, 331, 595-604. https://doi.org/10.1007/s00441-007-0556-6

Mallatt, J., \& Chen, J. Y. (2003). Fossil sister group of craniates: Predicted and found. Journal of Morphology, 258, 1-31. https://doi. org/10.1002/jmor.10081

Mallatt, J., Chen, J. Y., \& Holland, N. D. (2003). Comment on "A new species of yunnanozoan with implications for deuterostome evolution". Science, 300, 1372. https://doi.org/10.1126/science.1085064

Mallatt, J., \& Holland, N. (2013). Pikaia gracilens Walcott: Stem chordate, or already specialized in the Cambrian? Journal of Experimental Zoology Part B-Molecular and Developmental Evolution, 320B, 247271. https://doi.org/10.1002/jez.b.22500

Mallatt, J., \& Sullivan, J. (1998). 28 S and 18S rDNA sequences support the monophyly of lampreys and hagfishes. Molecular Biology and Evolution, 15, 1706-1718. https://doi.org/10.1093/oxfordjournals. molbev.a025897
Mallatt, J., Sullivan, J., \& Winchell, C. J. (2001). The relationship of lampreys to hagfishes: A spectral analysis of ribosomal DNA sequences. In P. E. Ahlberg (Ed.), Major events in early vertebrate evolution: Palaeontology, phylogeny, genetics and development (pp. 106-118). London, UK: Taylor \& Francis.

Märss, T., \& Ritchie, A. (1998). Articulated thelodonts (Agnatha) of Scotland. Transactions of the Royal Society of Edinburgh-Earth Sciences, 88, 143-195. https://doi.org/10.1017/S026359330000691X

Märss, T., Turner, S., \& Karatajūtē-Talimaa, V. (2007). Volume $1 B$ "Agnatha" II - Thelodonti. München, Germany: Verlag Dr. Friedrich Pfeil.

McCosker, J. E. (1977). The osteology, classification, and relationships of the eel family Ophichthidae. Proceedings of the California Academy of Science, 41, 1-123.

McCosker, J. E. (2004). A new species of finless snake eel (Anguilliformes: Ophichthidae) from Ascension island, with comments on Ichthyapus acutirostris. Proceedings of the California Academy of Science, 55, 169-173.

McCoy, V. E., Saupe, E. E., Lamsdell, J. C., Tarhan, L. G., McMahon, S., Lidgard, S., ...Briggs, D. E. G. (2016). The 'Tully monster' is a vertebrate. Nature, 532, 496-499. https://doi.org/10.1038/nature16992

McHenry, M. J. (2005). The morphology, behavior, and biomechanics of swimming in ascidian larvae. Canadian Journal of Zoology, 83, 62-74. https://doi.org/10.1139/z04-157

McMillan, C. B., \& Wisner, R. L. (2004). Review of the hagfishes (Myxinidae, Myxiniformes) of the northwestern Pacific Ocean, with descriptions of three new species, Eptatretus fernholmi, Paramyxine moki, and P. walkeri. Zoological Studies, 43, 51-73.

McNeill Alexander, R. (1967). Functional design in fishes. London, UK: Hutchinson \& Co Ltd.

Meek, S. E., \& Hildebrand, S. F. (1923). The marine fishes of Panama. Part I. Field Museum of Natural History Publication - Zoölogical Series, 15, 1-330. https://doi.org/10.5962/bhl.title.2887

Miles, R. S. (1970). Remarks on the vertebral column and caudal fin of acanthodian fishes. Lethaia, 3, 343-362. https://doi. org/10.1111/j.1502-3931.1970.tb00828.x

Miles, R. S. (1973). Articulated acanthodian fishes from the Old Red Sandstone of England, with a review of the structure and evolution of the acanthodian shoulder-girdle. Bulletin of the British Museum (Natural History) - Geology, 24, 111-213.

Miles, R. S., \& Westoll, T. S. (1968). The placoderm fish Coccosteus cuspidatus Miller ex Agassiz from the Middle Old Red Sandstone of Scotland. Part 1. Descriptive morphology. Transactions of the Royal Society of Edinburgh, 67, 373-476. https://doi.org/10.1017/S0080 456800024078

Miles, R. S., \& Young, G. C. (1977). Placoderm interrelationships reconsidered in the light of new ptyctodontids from Gogo, Western Australia. In S. Mahala Andrews, R. S. Miles, \& A. D. Walker (Eds.), Problems in vertebrate evolution (pp. 123-198). London, UK: Academic Press.

Miller, R. F., Cloutier, R., \& Turner, S. (2003). The oldest articulated chondrichthyan from the Early Devonian period. Nature, 425, 501-504. https://doi.org/10.1038/nature02001

Mivart, S. G. (1879). Notes on the fins of elasmobranchs, with considerations on the nature and homologues of vertebrate limbs. Transactions of the Zoological Society of London, 10, 439-484. https:// doi.org/10.1111/j.1096-3642.1879.tb00460.x

Miyashita, T. (2012). Comparative analysis of the anatomy of the Myxinoidea and the ancestry of early vertebrate lineages. M.Sc. thesis, University of Alberta, 407 pages.

Miyashita, T., Coates, M. I., Farrar, R., Larson, P., Manning, P. L., Wogelius, R. A., ...Currie, P. J. (2019). Hagfish from the Cretaceous Tethys Sea and a reconciliation of the morphological-molecular conflict in early vertebrate phylogeny. Proceedings of the National Academy of Sciences of the United States of America, 116, 2146-2151. https://doi. org/10.1073/pnas.1814794116 
Mok, H. K., \& Kuo, C. H. (2001). Myxine formosana, a new species of hagfish (Myxiniformes: Myxinidae) from the southwestern waters of Taiwan. Ichthyological Research, 48, 295-297. https://doi. org/10.1007/s10228-001-8149-y

Moloshnikov, S. V. (2008). Devonian antiarchs (Pisces, Antiarchi) from Central and Southern European Russia. Paleontological Journal, 42, 691-773. https://doi.org/10.1134/s0031030108070010

Morris, S. C. (1979). The Burgess Shale (Middle Cambrian) fauna. Annual Review of Ecology and Systematics, 10, 327-349. https://doi. org/10.1146/annurev.es.10.110179.001551

Morris, S. C. (2006). Darwin's dilemma: The realities of the Cambrian 'explosion'. Philosophical Transactions of the Royal Society of London Series B: Biological Sciences, 361, 1069-1083. https://doi.org/10.1098/ rstb.2006.1846

Morris, S. C. (2008). A redescription of a rare chordate, Metaspriggina walcotti Simonetta and Insom, from the Burgess Shale (Middle Cambrian), British Columbia, Canada. Journal of Paleontology, 82, 424-430. https://doi.org/10.1666/06-130.1

Morris, S. C., \& Caron, J. B. (2012). Pikaia gracilens Walcott, a stem-group chordate from the Middle Cambrian of British Columbia. Biological Reviews, 87, 480-512. https://doi. org/10.1111/j.1469-185X.2012.00220.x

Morris, S. C., \& Caron, J. B. (2014). A primitive fish from the Cambrian of North America. Nature, 512, 419-422. https://doi.org/10.1038/natur e13414

Morris, S. C., \& Whittington, H. B. (1979). The animals of the Burgess Shale. Scientific American, 241, 122-133. https://doi.org/10.1038/ scientificamerican0779-122

Moy-Thomas, J. A., \& Miles, R. S. (1971). Palaeozoic fishes, 2nd ed. Philadelphia, PA: W. B. Saunders Company.

Mulvany, S., \& Motta, P. J. (2013). The morphology of the cephalic lobes and anterior pectoral fins in six species of batoids. Journal of Morphology, 274, 1070-1083. https://doi.org/10.1002/jmor.20163

Near, T. J., Eytan, R. I., Dornburg, A., Kuhn, K. L., Moore, J. A., Davis, M. P., ...Smith, W. L. (2012). Resolution of ray-finned fish phylogeny and timing of diversification. Proceedings of the National Academy of Sciences of the United States of America, 109, 13698-13703. https:// doi.org/10.1073/pnas.1206625109

Nelson, J. S., Grande, T. C., \& Wilson, M. V. H. (2016). Fishes of the World, 5 th ed. Hoboken, NJ: John Wiley \& Sons Inc.

Newman, M. J. (2002). A new naked jawless vertebrate from the Middle Devonian of Scotland. Palaeontology, 45, 933-941. https://doi. org/10.1111/1475-4983.00269

Newman, M. J., Davidson, R. G., Den Blaauwen, J. L., \& Burrow, C. J. (2012). The Early Devonian acanthodian Uraniacanthus curtus (Powrie, 1870) n. comb. from the Midland Valley of Scotland. Geodiversitas, 34, 739-759. https://doi.org/10.5252/g2012n4a2

Newman, M. J., \& Trewin, N. H. (2001). A new jawless vertebrate from the Middle Devonian of Scotland. Palaeontology, 44, 43-51. https:// doi.org/10.1111/1475-4983.00168

Nishino, A., \& Satoh, N. (2001). The simple tail of chordates: Phylogenetic significance of appendicularians. Genesis, 29, 36-45. https://doi. org/10.1002/1526-968x(200101)29:1<36:aid-gene1003>3.0.co;2-j

Novitskaya, L. I., \& Turner, S. (1998). Turinia pagei (Powrie): A new reconstruction of the soft organs of the cephalothorax. Memoirs of the Queensland Museum, 42, 533-544.

Onimaru, K., \& Kuraku, S. (2018). Inference of the ancestral vertebrate phenotype through vestiges of the whole-genome duplications. Briefings in Functional Genomics, 17, 352-361. https://doi. org/10.1093/bfgp/ely008

Ørvig, T. (1967). Some new acanthodian material from the Lower Devonian of Europe. Journal of the Linnean Society of London, Zoology, 47, 131-153. https://doi.org/10.1111/j.1096-3642.1967.tb01400.x

O'Shaughnessy, K. L., Dahn, R. D., \& Cohn, M. J. (2015). Molecular development of chondrichthyan claspers and the evolution of copulatory organs. Nature Communications, 6, 8. https://doi.org/10.1038/ ncomms7698

Ota, K. G., Fujimoto, S., Oisi, Y., \& Kuratani, S. (2011). Identification of vertebra-like elements and their possible differentiation from sclerotomes in the hagfish. Nature Communications, 2, 373. https:// doi.org/10.1038/ncomms1355

Ota, K. G., Fujimoto, S., Oisi, Y., \& Kuratani, S. (2013). Late development of hagfish vertebral elements. Journal of Experimental Zoology Part B: Molecular and Developmental Evolution, 320B, 129-139. https://doi. org/10.1002/jez.b.22489

O'Toole, B. (2002). Phylogeny of the species of the superfamily Echeneoidea (Perciformes: Carangoidei: Echeneidae, Rachycentridae, and Coryphaenidae), with an interpretation of echeneid hitchhiking behaviour. Canadian Journal of Zoology, 80, 596-623. https://doi. org/10.1139/z02-031

Owen, R. (1846). Lectures on the comparative anatomy and physiology of the vertebrate animals, delivered at the Royal College of Surgeons of England in 1844 and 1846, Part I - Fishes. London, UK: Longman, Brown, Green and Longmans.

Owen, R. (1849). On the nature of limbs, a discourse delivered on Friday, February 9, at an evening meeting of the Royal Institution of Great Britain. London, UK: John Van Voorst, Paternoster Row.

Owen, R. (1854). The principal forms of the skeleton and of the teeth. Philadelphia, PA: Blanchard and Lea.

Pan, J. (1992). New Galeaspids (Agnatha) from the Silurian and Devonian of China. Beijing, China: Geological Publishing House.

Patten, W. (1904). New fact concerning Bothriolepis. Biological Bulletin, 7, 113-124. https://doi.org/10.2307/1535537

Patterson, C. (1982). Morphological characters and homology. In K. A. Joysey, \& A. E. Friday (Eds.), Problems of phylogenetic reconstruction (pp. 21-74). London, UK: Academic Press.

Patterson, C. (1988). Homology in classical and molecular biology. Molecular Biology and Evolution, 5, 603-625. https://doi.org/10.1093/ oxfordjournals.molbev.a040523

Philippe, H., Lartillot, N., \& Brinkmann, H. (2005). Multigene analyses of bilaterian animals corroborate the monophyly of Ecdysozoa, Lophotrochozoa, and Protostomia. Molecular Biology and Evolution, 22, 1246-1253. https://doi.org/10.1093/molbev/msi111

Pietsch, T. W. (1984). Lophiiformes: Development and relationships. In H. G. Moser, W. J. Richards, D. M. Cohen, M. P. Fahay, A. W. Kendall, \& S. L. Richardson (Eds.), Ontogeny and Systematics of Fishes. Based on an international symposium dedicated to the memory of Elbert Halvor Ahlstrom (pp. 320-325). Lawrence, KS: The American Society of Ichthyologists and Herpetologists.

Pietsch, T. W., \& Orr, J. W. (2007). Phylogenetic relationships of deep-sea anglerfishes of the suborder Ceratioidei (Teleostei : Lophiiformes) based on morphology. Copeia, 2007, 1-34. https://doi. org/10.1643/0045-8511(2007)7[1:PRODAO]2.0.CO;2

Pletcher, F. T. (1963). The life history and distribution of lampreys in the Salmon and certain other rivers in British Columbia, Canada. M.Sc. thesis, University of British Columbia, 195 pages.

Poplin, C., Sotty, D., \& Janvier, P. (2001). Un myxinoïde (Craniata, Hyperotreti) dans le Konservat-Lagerstätte Carbonifère supérieur de Montceau-les-Mines (Allier, France). Comptes Rendus de l'Académie des Sciences Série II Fascicule a - Sciences de la Terre et des Planètes, 332, 345-350. https://doi.org/10.1016/S1251-8050(01)01537-3

Poss, S. G., \& Boschung, H. T. (1996). Lancelets (Cephalochordata: Branchiostomatidae): How many species are valid? Israel Journal of Zoology, 42, 13-66. https://doi.org/10.1080/00212 210.1996.10688872

Potvin-Leduc, D. (2017). Wellerodus priscus, un chondrichthyen avec aiguillons pairs du Dévonien Moyen (Givétien) de l'État de New York, ÉtatsUnis. M.Sc. thesis, Université du Québec à Rimouski, 115 pages.

Potvin-Leduc, D., Cloutier, R., Landing, E., VanAller Hernick, L., \& Mannolini, F. (2011). Fin spines and scales of the Middle Devonian 
shark Wellerodus priscus: Towards a chondrichthyan baüplan? Ichthyolith Issues, Special Publication, 12, 39-40.

Powrie, J. (1870). On the earliest known vestiges of vertebrate life; being a description of the fish remains of the Old Red Sandstone rocks of Forfarshire. Transactions of the Edinburgh Geological Society, 1, 284301. https://doi.org/10.1144/transed.1.3.284

Pradel, A., Sansom, I. J., Gagnier, P.-Y., Cespedes, R., \& Janvier, P. (2007). The tail of the Ordovician fish Sacabambaspis. Biology Letters, 3, 7275. https://doi.org/10.1098/rsbl.2006.0557

Pradel, A., Tafforeau, P., Maisey, J. G., \& Janvier, P. (2011). A new Paleozoic Symmoriiformes (Chondrichthyes) from the Late Carboniferous of Kansas (USA) and cladistic analysis of early chondrichthyans. PLoS ONE, 6, e24938. https://doi.org/10.1371/journal.pone.0024938

Pridmore, P. A., Barwick, R. E., \& Nicoll, R. S. (1997). Soft anatomy and the affinities of conodonts. Lethaia, 29, 317-328. https://doi. org/10.1111/j.1502-3931.1996.tb01667.x

Purnell, M. A. (1995). Microwear on conodont elements and macrophagy in the first vertebrates. Nature, 374, 798-800. https://doi. org/10.1038/374798a0

Putnam, N. H., Butts, T., Ferrier, D. E. K., Furlong, R. F., Hellsten, U., Kawashima, T., ...Rokhsar, D. S. (2008). The amphioxus genome and the evolution of the chordate karyotype. Nature, 453, 1064-U1063. https://doi.org/10.1038/nature06967

Qiao, T., King, B., Long, J. A., Ahlberg, P., \& Zhu, M. (2016). Early gnathostome phylogeny revisited: Multiple method consensus. PLoS ONE, 11, e0163157. https://doi.org/10.1371/journal.pone.0163157

Reif, W. E. (1982). Evolution of dermal skeleton and dentition in vertebrates: The odontode regulation theory. In M. K. Hecht, B. Wallace, \& G. T. Prance (Eds.), Evolutionary biology (pp. 287-368). New York, NY: Plenum Press.

Reimchen, T. E., \& Temple, N. F. (2004). Hydrodynamic and phylogenetic aspects of the adipose fin in fishes. Canadian Journal of Zoology, 82, 910-916. https://doi.org/10.1139/z04-069

Renaud, C. B. (2011). Lampreys of the world. An annotated and illustrated catalogue of lamprey species known to date. FAO species catalogue for fishery purposes No. 5. Rome, Italy: FAO.

Rice, H. J. (1880). Observations upon the habits, structure and development of Amphioxus lanceolatus. American Naturalist, 14, 1-19. https:// doi.org/10.1086/272471

Richardson, E. S. (1966). Wormlike fossil from the Pennsylvanian of Illinois. Science, 151, 75-76. https://doi.org/10.1126/science.151.3706.75-a

Richardson, L. R. (1953). Neomyxine n.g. (Cyclostomata) based on Myxine biniplicata Richardson and Jowett 1951, and further data on the species. Transactions of the Royal Society of New Zealand, 81, 379-383.

Richardson, L. R. (1958). A new genus and species of Myxinidae. Transactions of the Royal Society of New Zealand, 85, 283-287.

Richter, P., \& Moritz, T. (2017). Lessons from the first dorsal fin in atheriniforms - A new mode of dorsal fin development and its phylogenetic implications. Journal of Morphology, 278, 848-864. https://doi. org/10.1002/jmor.20679

Riley, C., Cloutier, R., \& Grogan, E. D. (2017). Similarity of morphological composition and developmental patterning in paired fins of the elephant shark. Scientific Reports, 7, 9985. https://doi.org/10.1038/ s41598-017-10538-0

Ritchie, A. (1964). New light on the morphology of the Norwegian Anaspida. Skrifter Utgitt Av Det Norske Videnskaps-Akademi I Oslo. I. Matematiske-naturvidenskapslige Klasse. Ny Serie, 14, 1-35.

Ritchie, A. (1967). Ateleaspis tesselata Traquair, a non-cornuate cephalaspid from the Upper Silurian of Scotland. Journal of the Linnean Society of London, Zoology, 47, 69-81. https://doi. org/10.1111/j.1096-3642.1967.tb01396.x

Ritchie, A. (1968a). New evidence on Jamoytius kerwoodi White, an important ostracoderm from the Silurian of Lanarkshire, Scotland. Palaeontology, 11, 21-39.
Ritchie, A. (1968b). Phlebolepis elegans Pander, an Upper Silurian thelodont from Oesel, with remarks on the morphology of thelodonts. In T. Ørvig (Ed.), Current problems of lower vertebrate phylogeny: Proceeding of the Fourth Nobel Symposium (pp. 81-88). Stockholm, Sweden: Almqvist \& Wiskell.

Ritchie, A. (1980). The Late Silurian anaspid genus Rhyncholepis from Oesel, Estonia, and Ringerike, Norway. American Museum Novitates, 2699, 1-18.

Ritchie, A. (1985). Arandaspis prionotolepis, the southern four-eyed fish. In P. V. Rich, G. F.VanTets, \& F. Knight (Eds.), Kadimakara: Extinct Vertebrates from Australia (pp. 95-101). Victoria, Australia: Pioneer Design Studio.

Ritchie, A., \& Gilbert-Tomlinson, J. (1977). First Ordovician vertebrates from the southern hemisphere. Alcheringa, 1, 351-368. https://doi. org $/ 10.1080 / 03115517708527770$

Roberts, T. R. (1981). Sundasalangidae, a new family of minute freshwater salmoniform fishes from southeast Asia. Proceedings of the California Academy of Sciences, 42, 295-302.

Robertson, G. M. (1935a). Oeselaspis, a new genus of ostracoderm. American Journal of Science, 5, 453-461. https://doi.org/10.2475/ajs. s5-29.173.453

Robertson, G. M. (1935b). The ostracoderm genus Dartmuthia Patten. American Journal of Science, 5, 323-335. https://doi.org/10.2475/ajs. s5-29.172.323

Robertson, G. M. (1938a). The Tremataspidae. Part I. American Journal of Science, 35, 172-206. https://doi.org/10.2475/ajs.s5-35.207.172

Robertson, G. M. (1938b). The Tremataspidae. Part II. American Journal of Science, 35, 273-296. https://doi.org/10.2475/ajs.s5-35.208.273

Robertson, G. M. (1941). The ostracoderm order Anaspida, with description of some Upper Silurian material. Transactions of the Kansas Academy of Science, 44, 314-317. https://doi.org/10.2307/3624894

Rondelet, G. (1558). La première partie de l'histoire entière des poissons. Lyon, France: La Masse d'Or.

Rosenberger, L. J. (2001). Pectoral fin locomotion in batoid fishes: Undulation versus oscillation. Journal of Experimental Biology, 204, 379-394.

Rowe, T. (2004). Chordate phylogeny and development. In J. Cracraft, \& M. J. Donoghue (Eds.), Assembling the tree of life (pp. 384-409). New York, NY: Oxford University Press.

Ruvinsky, I., \& Gibson-Brown, J. J. (2000). Genetic and developmental bases of serial homology in vertebrate limb evolution. Development, 127, 5233-5244.

Sallan, L., Giles, S., Sansom, R. S., Clarke, J. T., Johanson, Z., Sansom, I. J., \& Janvier, P. (2017). The 'Tully monster' is not a vertebrate: Characters, convergence and taphonomy in Paleozoic problematic animals. Palaeontology, 60, 149-157. https://doi.org/10.1111/pala.12282

Sandon, H. (1956). An abnormal specimen of Synodontis membranaceus (Teleostei, Siluroidea), with a discussion on the evolutionary history of the adipose fin in fish. Proceedings of the Zoological Society of London, 127(4), 453-459. https://doi.org/10.1111/j.1096-3642.1956. tb00481.x

Sansom, I. J., Smith, M. M., \& Smith, M. P. (1996). Scales of thelodont and shark-like fishes from the Ordovician of Colorado. Nature, 379, 628-630. https://doi.org/10.1038/379628a0

Sansom, I. J., Smith, M. P., Smith, M. M., \& Turner, P. (1997). Astraspis The anatomy and histology of an Ordovician fish. Palaeontology, 40, 625-643.

Sansom, R. S. (2007). A review of the problematic osteostracan genus Auchenaspis and its role in Thyestidian evolution. Palaeontology, 50, 1001-1011. https://doi.org/10.1111/j.1475-4983.2007.00686.x

Sansom, R. S. (2008). The origin and early evolution of the Osteostraci (Vertebrata): A phylogeny for the Thyestiida. Journal of Systematic Palaeontology, 6, 317-332. https://doi.org/10.1017/s147720190 7002386 
Sansom, R. S. (2009). Phylogeny, classification and character polarity of the Osteostraci (Vertebrata). Journal of Systematic Palaeontology, 7, 95-115. https://doi.org/10.1017/s1477201908002551

Sansom, R. S., Gabbott, S. E., \& Purnell, M. A. (2013). Unusual anal fin in a Devonian jawless vertebrate reveals complex origins of paired appendages. Biology Letters, 9, 20130002. https://doi.org/10.1098/ rsbl.2013.0002

Satoh, N., Rokhsar, D., \& Nishikawa, T. (2014). Chordate evolution and the three-phylum system. Proceedings of the Royal Society B: Biological Sciences, 281, 20141729. https://doi.org/10.1098/rspb.2014.1729

Schaefer, J. T., \& Summers, A. P. (2005). Batoid wing skeletal structure: Novel morphologies, mechanical implications, and phylogenetic patterns. Journal of Morphology, 264, 298-313. https://doi.org/10.1002/ jmor.10331

Schaeffer, B. (1981). The xenacanth shark neurocranium, with comments on elasmobranch monophyly. Bulletin of the American Museum of Natural History, 169, 1-66.

Schaeffer,B.(1987).Deuterostomemonophylyandphylogeny. Evolutionary Biology, 21, 179-235. https://doi.org/10.1007/978-1-4615-6986-2_8

Schaeffer, B., \& Thomson, K. S. (1980). Reflections on agnathan-gnathostome relationships. In L. L. Jacobs (Ed.), Aspects of vertebrate history (pp. 19-33). Flagstaff, AZ: Museum of Northern Arizona Press.

Schaeffer, B., \& Williams, M. (1977). Relationships of fossil and living elasmobranchs. American Zoologist, 17, 293-302. https://doi. org/10.1093/icb/17.2.293

Schmalhausen, J. J. (1913). Zur Morphologie der unpaaren Flossen. II. Bau und Phylogenese der unpaaren Flossen und insbesonders der Schwanzflosse der Fische. Zeitschrift für wissenschaftliche Zoologie, 104, 1-80.

Schubert, M., Escriva, H., Xavier-Neto, J., \& Laudet, V. (2006). Amphioxus and tunicates as evolutionary model systems. Trends in Ecology \& Evolution, 21, 269-277. https://doi.org/10.1016/j. tree.2006.01.009

Schultze, H.-P. (1986). Dipnoans as sarcopterygians. Journal of Morphology, 190, 39-74. https://doi.org/10.1002/jmor.1051900407

Schultze, H.-P. (1992). Fossilium Catalogus I: Animalia. Pars 131. Dipnoi. Amsterdam, The Netherlands: Kugler Publications.

Schultze, H.-P. (1993). Osteichthyes: Sarcopterygii. In M. J. Benton (Ed.), The fossil record 2 (pp. 657-663). London, UK: Chapman \& Hall.

Schultze, H.-P., \& Cumbaa, S. L. (2001). Dialipina and the characters of basal actinopterygians. In P. E. Ahlberg (Ed.), Major events in early vertebrate evolution: Palaeontology, phylogeny, genetics and development (pp. 315-332). London, UK: Taylor \& Francis.

Scott, B. R., \& Wilson, M. V. H. (2012). A new species of Waengsjoeaspis (Cephalaspidomorpha, Osteostraci) from the Early Devonian of northwestern Canada, with a redescription of W. nahanniensis and implications for growth, variation, morphology, and phylogeny. Journal of Vertebrate Paleontology, 32, 1235-1253. https://doi. org/10.1080/02724634.2012.694514

Scott, B. R., \& Wilson, M. V. H. (2013). A new species of osteostracan from the Lochkovian (Early Devonian) of the Mackenzie Mountains, with comments on body size, growth, and geographic distribution in the genus Machairaspis. Canadian Journal of Earth Sciences, 50, 127134. https://doi.org/10.1139/cjes-2012-0100

Sfakiotakis, M., Lane, D. M., \& Davies, J. B. C. (1999). Review of fish swimming modes for aquatic locomotion. IEEE Journal of Oceanic Engineering, 24, 237-252. https://doi.org/10.1109/48.757275

Shenkar, N., \& Swalla, B. J. (2011). Global diversity of Ascidiacea. PLoS ONE, 6, e20657. https://doi.org/10.1371/journal.pone.0020657

Shimeld, S. M., \& Donoghue, P. C. J. (2012). Evolutionary crossroads in developmental biology: Cyclostomes (lamprey and hagfish). Development, 139, 2091-2099. https://doi.org/10.1242/dev.074716

Shimeld, S. M., \& Holland, P. W. H. (2000). Vertebrate innovations. Proceedings of the National Academy of Sciences of the United States of America, 97, 4449-4452. https://doi.org/10.1073/pnas.97.9.4449
Shu, D. G. (2003). A paleontological perspective of vertebrate origin. Chinese Science Bulletin, 48, 725-735. https://doi. org/10.1360/03wd0026

Shu, D. G. (2005). On the phylum Vetulicolia. Chinese Science Bulletin, 50, 2342-2354. https://doi.org/10.1360/982005-1081

Shu, D. G. (2008). Cambrian explosion: Birth of tree of animals. Gondwana Research, 14, 219-240. https://doi.org/10.1016/j.gr.2007.08.004

Shu, D. G., Chen, L., Zhang, X.-L., Han, J., \& Li, Y. (2001). Chengjiang Lagerstätte and earliest-known chordates. Zoological Science, 18, 447-448.

Shu, D.-G., Luo, H.-L., Conway Morris, S., Zhang, X.-L., Hu, S.-X., Chen, L., ...Chen, L.-Z. (1999). Lower Cambrian vertebrates from South China. Nature, 402, 42-46. https://doi.org/10.1038/46965

Shu, D. G., \& Morris, S. C. (2003). Response to comment on "A new species of yunnanozoan with implications for deuterostome evolution". Science, 300, 1372-1372. https://doi.org/10.1126/science.1079846

Shu, D.-G., Morris, S. C., Han, J., Zhang, Z.-F., Yasui, K., Janvier, P., ...Liu, H.-Q. (2003). Head and backbone of the Early Cambrian vertebrate Haikouichthys. Nature, 421, 526-529. https://doi.org/10.1038/natur e01264

Shu, D. G., Morris, S. C., \& Zhang, X.-L. (1996). A Pikaia-like chordate from the Lower Cambrian of China. Nature, 384, 157-158. https:// doi.org/10.1038/384157a0

Shu, D. G., Morris, S. C., Zhang, Z. F., \& Han, J. (2010). The earliest history of the deuterostomes: The importance of the Chengjiang FossilLagerstatte. Proceedings of the Royal Society B: Biological Sciences, 277, 165-174. https://doi.org/10.1098/rspb.2009.0646

Shu, D. G., Morris, S. C., Zhang, Z. F., Liu, J. N., Han, J., Chen, L., ...Li, Y. (2003). A new species of yunnanozoan with implications for deuterostome evolution. Science, 299, 1380-1384. https://doi. org/10.1126/science.1079846

Shu, D. G., Zhang, X., \& Chen, L. (1996). Reinterpretation of Yunnanozoon as the earliest known hemichordate. Nature, 380, 428-430. https:// doi.org/10.1038/380428a0

Shubin, N. H., Daeschler, E. B., \& Jenkins, F. A. (2006). The pectoral fin of Tiktaalik roseae and the origin of the tetrapod limb. Nature, 440, 764-771. https://doi.org/10.1038/nature04637

Shubin, N. H., Daeschler, E. B., \& Jenkins, F. A. (2014). Pelvic girdle and fin of Tiktaalik roseae. Proceedings of the National Academy of Sciences of the United States of America, 111, 893-899. https://doi.org/10.1073/ pnas.1322559111

Shubin, N. H., Tabin, C., \& Carroll, S. (1997). Fossils, genes and the evolution of animal limbs. Nature, 388, 639-648. https://doi. org $/ 10.1038 / 41710$

Siebert, D. J. (1997). Notes on the anatomy and relationships of Sundasalanx Roberts (Teleostei, Clupeidae), with descriptions of four new species from Borneo. Bulletin of the Natural History Museum. London. Zoology Series, 63, 13-26.

Simonetta, A. M., \& Insom, E. (1993). New animals from the Burgess Shale (Middle Cambrian) and their possible significance for the understanding of the Bilateria. Bollettino Di Zoologia, 60, 97-107. https ://doi.org/10.1080/11250009309355797

Singh, T., Tsagkogeorga, G., Delsuc, F., Blanquart, S., Shenkar, N., Loya, Y., ...Huchon, D. (2009). Tunicate mitogenomics and phylogenetics: Peculiarities of the Herdmania momus mitochondrial genome and support for the new chordate phylogeny. BMC Genomics, 10, 534. https://doi.org/10.1186/1471-2164-10-534

Smith, H. M. (1907). The fishes of North Carolina. Raleigh, NC: North Carolina Geological and Economic Survey.

Smith, M. P., Sansom, I. J., \& Cochrane, K. D. (2001). The Cambrian origin of vertebrates. In P. E. Ahlberg (Ed.), Major events in early vertebrate evolution: Palaeontology, phylogeny, genetics and development (pp. 6784). London, UK: Taylor \& Francis.

Soehn, K. L., \& Wilson, M. V. H. (1990). A complete, articulated heterostracan from Wenlockian (Silurian) beds of the Delorme group, 
Mackenzie Mountains, Northwest Territories, Canada. Journal of Vertebrate Paleontology, 10, 405-419. https://doi.org/10.1080/02724 634.1990.10011825

Stensiö, E. A. (1927). The Downtonian and Devonian vertebrates of Spitsbergen. Part I. Family Cephalaspidae. Skrifter om Svalbard og Nordishavet, 12, 1-391.

Stensiö, E. A. (1932). The Cephalaspids of Great Britain. London, UK: British Miseum (Natural History).

Stensiö, E. A. (1937). On the Devonian coelacanthids of Germany with special reference to the dermal skeleton. Kungliga Svenska Vetenskapsakademiens Handlingar, 3, 1-56.

Stensiö, E. A. (1939). A new anaspid from the Upper Devonian of Scaumenac Bay in Canada, with remarks on the other anaspids. Kungliga Svenska Vetenskapsakademiens Handlingar, 18, 1-25.

Stensiö, E. A. (1948). On the Placodermi of the Upper Devonian of East Greenland. II. Antiarchi: Subfamily Bothriolepinae. With an attempt at a revision of the previously described species of that family. Meddelelser om Grønland, 139, 1-622.

Stensiö, E. A. (1964). Les cyclostomes fossiles ou ostracodermes. In J. Piveteau (Ed.), Traité de Paléontologie. Tome IV. L'origine des vertébrés, leur expansion dans les eaux douces et le milieu marin. Premier volume: Vertébrés (généralités), agnathes (pp. 96-382). Paris, France: Masson et Cie.

Stewart, T. A. (2015). The origin of a new fin skeleton through tinkering. Biology Letters, 11, 20150415. https://doi.org/10.1098/ rsbl.2015.0415

Stewart, T. A., Bonilla, M. M., Ho, R. K., \& Hale, M. E. (2019). Adipose fin development and its relation to the evolutionary origins of median fins. Scientific Reports, 9, 512. https://doi.org/10.1038/ s41598-018-37040-5

Stewart, T. A., \& Hale, M. E. (2013). First description of a musculoskeletal linkage in an adipose fin: Innovations for active control in a primitively passive appendage. Proceedings of the Royal Society B: Biological Sciences, 280, 20122159. https://doi.org/10.1098/rspb.2012.2159

Stewart, T. A., Smith, W. L., \& Coates, M. I. (2014). The origins of adipose fins: An analysis of homoplasy and the serial homology of vertebrate appendages. Proceedings of the Royal Society B: Biological Sciences, 281, 20133120. https://doi.org/10.1098/rspb.2013.3120

Stock, D. W., \& Whitt, G. S. (1992). Evidence from 18 S ribosomal RNA sequences that lampreys and hagfishes form a natural group. Science, 257, 787-789. https://doi.org/10.1126/science.1496398

Stokes, M. D. (1996). Larval settlement, post-settlement growth and secondary production of the Florida lancelet (= amphioxus) Branchiostoma floridae. Marine Ecology Progress Series, 130, 71-84. https://doi.org/10.3354/meps130071

Stokes, M. D., \& Holland, N. D. (1998). The lancelet. American Scientist, 86, 552-560. https://doi.org/10.1511/1998.43.799

Storms, R. (1888). The adhesive disk of Echeneis. The Annals and Magazine of Natural History, Sixth Series, 2, 67-76. https://doi. org/10.1080/00222938809460878

Swartz, B. (2012). A marine stem-tetrapod from the Devonian of western North America. PLoS ONE, 7, e33683. https://doi.org/10.1371/journ al.pone. 0033683

Sweet, W. C. (1988). The Conodonta: Morphology, taxonomy, paleoecology, and evolutionary history of a long-extinct animal phylum. Oxford, UK: Clarendon Press.

Sweet, W. C., \& Donoghue, P. C. J. (2001). Conodonts: Past, present, future. Journal of Paleontology, 75, 1174-1184. https://doi.org/10.1666 /0022-3360(2001)075<1174:CPPF>2.0.CO;2

Tabin, C., \& Laufer, E. (1993). Hox genes and serial homology. Nature, 361, 692-693. https://doi.org/10.1038/361692a0

Tamura, K., Kuraishi, R., Saito, D., Masaki, H., Ide, H., \& Yonei-Tamura, S. (2001). Evolutionary aspects of positioning and identification of vertebrate limbs. Journal of Anatomy, 199, 195-204. https://doi.org/1 0.1046/j.1469-7580.2001.19910195.x
Tanaka, M., Cohn, M. J., Ashby, P., Davey, M., Martin, P., \& Tickle, C. (2000). Distribution of polarizing activity and potential for limb formation in mouse and chick embryos and possible relationships to polydactyly. Development, 127, 4011-4021.

Tanaka, M., Munsterberg, A., Anderson, W. G., Prescott, A. R., Hazon, N., \& Tickle, C. (2002). Fin development in a cartilaginous fish and the origin of vertebrate limbs. Nature, 416, 527-531. https://doi. org/10.1038/416527a

Tarlo, L. B. (1964). Psammosteiformes (Agnatha) - A review with descriptions of new material from the Lower Devonian of Poland. I. General Part. Paleontologia Polonica, 13, 1-135.

Tarlo, L. B. (1965). Psammosteiformes (Agnatha) - A review with descriptions of new material from the Lower Devonian of Poland. II. Systematic part. Paleontologia Polonica, 15, 1-167.

Taverne, L. (1997). Osorioichthys marginis, "Paléonisciforme" du Famennien de Belgique, et la phylogénie des actinoptérygiens dévoniens (Pisces). Bulletin de l' Institut Royal des Sciences Naturelles de Belgique, 67, 57-78.

Thacher, J. K. (1877). Median and paired fins, a contribution to the history of vertebrate limbs. Transactions of the Connecticut Academy of Arts and Science, 3, 281-308.

Thorson, T. B., Langhammer, J. K., \& Oetinger, M. I. (1988). Periodic shedding and replacement of venomous caudal spines, with special reference to South American freshwater stingrays, Potamotrygon spp. Environmental Biology of Fishes, 23, 299-314. https://doi. org/10.1007/BF00005241

Tinker, S. W. (1944). Hawaiian fishes. A hanbook of the fishes found among the Islands of the Central Pacific Ocean. Honolulu, Hawaii: Tongg Publishing Company.

Traquair, R. H. (1900). Report on fossil fishes collected by the geological survey of Scotland in the Silurian rocks of the south of Scotland. Transactions of the Royal Society of Edinburgh, 39, 827-864. https:// doi.org/10.1017/S0080456800035237

Trinajstic, K., Boisvert, C., Long, J., Maksimenko, A., \& Johanson, Z. (2014). Pelvic and reproductive structures in placoderms (stem gnathostomes). Biological Reviews, 90, 467-501. https://doi.org/10.1111/ brv.12118

Trueb, L., \& Cloutier, R. (1991). A phylogenetic investigation of the inter- and intrarelationships of the Lissamphibia (Amphibia: Temnospondyli). In H. P. Schultze, \& L. Trueb (Eds.), Origins of major groups of tetrapods: Controversies and consensus (pp. 223-313). Ithaca, NY: Cornell University Press.

Tulenko, F. J., McCauley, D. W., MacKenzie, E. L., Mazan, S., Kuratani, S., Sugaharad, F., ...Burke, A. C. (2013). Body wall development in lamprey and a new perspective on the origin of vertebrate paired fins. Proceedings of the National Academy of Sciences of the United States of America, 110, 11899-11904. https://doi.org/10.1073/pnas.13042 10110

Turner, S. (1982). A new articulated thelodont (Agnatha) from the Early Devonian of Britain. Palaeontology, 25, 879-889.

Turner, S. (1991). Monophyly and interrelationships of the Thelodonti. In M.-M. Chang, Y.-H. Liu, \& G.-R. Zhang (Eds.), Early vertebrates and related problems of evolutionary biology (pp. 87-119). Beijing, China: Science Press.

Turner, S. (1992). Thelodont lifestyles. In E. Mark-Kurik (Ed.), Fossil fishes as living animals (pp. 21-40). Tallinn, Estonia: Academy of Science of Estonia.

Turner, S. (2004). Early vertebrates: Analysis from microfossil evidence. In G. Arratia, M. V. H. Wilson, \& R. Cloutier (Eds.), Recent advances in the origin and early radiation of vertebrates (pp. 67-94). München, Germany: Verlag Dr. Friedrich Pfeil.

Turner, S., Burrow, C. J., Schultze, H.-P., Blieck, A., Reif, W. E., Rexroad, C. B., ...Nowlan, G. S. (2010). False teeth: Conodont-vertebrate phylogenetic relationships revisited. Geodiversitas, 32, 545-594. https:// doi.org/10.5252/g2010n4a1 
Turner, S., \& Miller, R. F. (2005). New ideas about old sharks: A rare fossil sheds light on the poorly understood relationship between early sharks and bony fishes. American Scientist, 93, 244-252. https://doi. org/10.1511/2005.53.965

Turner, S., \& van der Brugghen, W. (1993). The Thelodonti, an important but enigmatic group of Paleozoic fishes. Modern Geology, 18, 125-140.

Turner, S., \& Young, G. C. (1992). Thelodont scales from the Middle Late Devonian Aztec Siltstone, Southern Victoria-Land, Antarctica. Antarctic Science, 4, 89-105. https://doi.org/10.1017/S095410209 2000142

Uyeno, T. (1991). Observations on locomotion and feeding of released coelacanths, Latimeria chalumnae. Environmental Biology of Fishes, 32, 267-273. https://doi.org/10.1007/bf00007459

van der Brugghen, W. (1994). Over magen en staarten van thelodonten. Grondboor en Hamer, 4(5), 87-93.

van Eeden, F. J. M., Granato, M., Schach, U., Brand, M., FurutaniSeiki, M., Haffter, P., ...NussleinVolhard, C. (1996). Genetic analysis of fin formation in the zebrafish, Danio rerio. Development, 123, 255-262.

Vézina, D. (1990). Les Plourdosteidae fam. nov. (Placodermi, Arthrodira) et leurs relations phylétiques au sein des Brachythoraci. Canadian Journal of Earth Sciences, 27, 677-683. https://doi.org/10.1139/ e90-065

Vézina, D. (1996). Placodermi (Antiarchi and Arthrodira). In H.-P. Schultze, \& R. Cloutier (Eds.), Devonian fishes and plants of Miguasha, Quebec, Canada (pp. 141-148). München, Germany: Verlag Dr. Friedrich Pfeil.

Vladykov, V. D. (1973). A female sea lamprey (Petromyzon marinus) with a true anal fin, and the question of the presence of an anal fin in Petromyzonidae. Canadian Journal of Zoology, 51, 221-224. https:// doi.org/10.1139/z73-032

Vladykov, V. D., \& Kott, E. (1980). Description and key to metamorphosed specimens and ammocoetes of Petromyzonidae found in the Great Lakes region. Canadian Journal of Fisheries and Aquatic Sciences, 37, 1616-1625. https://doi.org/10.1139/f80-208

von Koenen, A. (1895). Uber einige Fishreste des norddeutschen und böhmischen Devons. Abhandlungen der Königlichen Gesellschaft der Wissenschaften zu Göttingen, 40, 1-37.

von Zittel, K. A., \& Woodward, A. S. (1902). Class I. Pisces. In C. R. Eastman (Ed.), Text-book of palaeontology (pp. 2-114). New York, NY: McMillan and Co. Ltd.

Vorobyeva, E. I., \& Hinchliffe, R. (1996). From fins to limbs Developmental perspectives on paleontological and morphological evidence. Evolutionary Biology, 29, 263-311.

Vorobyeva, E. I., \& Schultze, H.-P. (1991). Description and systematics of panderichthyid fishes with comments on their relationship to tetrapods. In H.-P. Schultze, \& L. Trueb (Eds.), Origins of the higher groups of tetrapods: Controversy and consensus (pp. 68-109). Ithaca, NY: Cornell University Press.

Voskoboinikova, O. S., \& Kudryavtseva, O. Y. (2014). Development of bony skeleton in the ontogeny of lumpfish Cyclopterus lumpus (Cyclopteridae, Scorpaeniformes). Journal of Ichthyology, 54, 301310. https://doi.org/10.1134/S0032945214030163

Walcott, C. D. (1911). Cambrian geology and paleontology II - Middle Cambrian annelids. Smithsonian Miscellaneous Collections, 57, 109-144.

Walcott, C. D. (1931). Addenda to descriptions of Burgess Shale fossils. Smithsonian Miscellaneous Collections, 85, 1-46.

Wang, B. G., He, L. W., Ehehalt, F., Geetha-Loganathan, P., Nimmagadda, S., Christ, B., ... Huang, R. J. (2005). The formation of the avian scapula blade takes place in the hypaxial domain of the somites and requires somatopleure-derived BMP signals. Developmental Biology, 287, 11-18. https://doi.org/10.1016/.ydbio.2005.08.016

Wängsjö, G. (1952). The Downtonian and Devonian vertebrates of Spitsbergen. IX. Morphologic and systematic studies of the Spitsbergen cephalaspids, results of Th. Vogt's expedition 1928 and the English-Norwegian-Swedish expedition 1939. Norsk Polarinstitutt Skrifter, 97, 1-611.

Warren, A., Currie, B. P., Burrow, C., \& Turner, S. (2000). A redescription and reinterpretation of Gyracanthides murrayi Woodward 1906 (Acanthodii, Gyracanthidae) from the Lower Carboniferous of the Mansfield Basin, Victoria, Australia. Journal of Vertebrate Paleontology, 20, 225-242. https://doi.org/10.1671/02724634(2000)020[0225:ararog]2.0.co;2

Watson, D. M. S. (1934). The interpretation of arthrodires. Proceedings of the Zoological Society of London, 104(3), 437-464. https://doi. org/10.1111/j.1096-3642.1934.tb01643.x

Watson, D. M. S. (1937). The acanthodian fishes. Philosophical Transactions of the Royal Society of London Series B: Biological Sciences, 228, 49-146. https://doi.org/10.1098/rstb.1937.0009

Watson, D. M. S. (1954). A consideration of ostracoderms. Philosophical Transactions of the Royal Society of London Series B: Biological Sciences, 238, 1-25. https://doi.org/10.1098/rstb.1954.0004

Webb, P. W. (1975). Hydrodynamics and energetics of fish propulsion. Bulletin of the Fisheries Research Board of Canada, 190, 1-158.

Webb, P. W. (1982). Locomotor patterns in the evolution of actinopterygian fishes. American Zoologist, 22, 329-342. https://doi. org/10.1093/icb/22.2.329

Webb, P. W. (1984). Body form, locomotion and foraging in aquatic vertebrates. American Zoologist, 24, 107-120. https://doi.org/10.1093/ $\mathrm{icb} / 24.1 .107$

Wendruff, A. J., \& Wilson, M. V. H. (2012). A fork-tailed coelacanth, Rebellatrix divaricerca, gen. et sp. nov. (Actinistia, Rebellatricidae, fam. nov.), from the Lower Triassic of Western Canada. Journal of Vertebrate Paleontology, 32, 499-511. https://doi.org/10.1080/02724 634.2012.657317

Westoll, T. S. (1945a). A new cephalaspid fish from the Downtonian of Scotland, with notes on the structure and classification of ostracoderms. Transactions of the Royal Society of Edinburgh-Earth Sciences, 61, 341-357. https://doi.org/10.1017/S0080456800004786

Westoll, T. S. (1945b). The paired fins of placoderms. Transactions of the Royal Society of Edinburgh, 61, 381-398. https://doi.org/10.1017/ S0080456800004804

Westoll, T. S. (1949). On the evolution of the Dipnoi. In G. L. Jepsen, E. Mayr, \& G. G. Simpson (Eds.), Genetics, paleontology, and evolution (pp. 121-184). Princeton, NJ: Princeton University Press.

Westoll, T. S. (1958). The lateral fin-fold theory and the pectoral fins of ostracoderms and early fishes. In T. S. Westoll (Ed.), Studies on fossil vertebrates (pp. 180-211). London, UK: The Athlone Press, University of London.

White, E. I. (1935). The ostracoderm Pteraspis Kner and the relationships of the agnathous vertebrates. Philosophical Transactions of the Royal Society of London Series B: Biological Sciences, 225, 381-457. https:// doi.org/10.1098/rstb.1935.0015

White, E. I. (1946). Jamoytius kerwoodi, a new chordate from the Silurian of Lanarkshire, Scotland. Geological Magazine, 83, 89-97. https://doi. org/10.1017/S0016756800082856

White, E. I. (1958). On Cephalaspis lyelli Agassiz. Palaeontology, 1, 99-105.

Wickstead, J. H. (1969). Some further comments on Jamoytius kerwoodi White. Zoological Journal of the Linnean Society, 48, 421-422. https:// doi.org/10.1111/j.1096-3642.1969.tb00721.x

Wiley, A. (1894). Amphioxus and the ancestry of the vertebrates. New York, NY: MacMillan and Co.

Wilson, M.V.H., \& Caldwell, M. W. (1993). New Silurian and Devonian forktailed 'thelodonts' are jawless vertebrates with stomachs and deep bodies. Nature, 361, 442-444. https://doi.org/10.1038/361442a0

Wilson, M. V. H., \& Caldwell, M. W. (1998). The Furcacaudiformes: A new order of jawless vertebrates with thelodont scales, based on articulated Silurian and Devonian fossils from northern Canada. Journal of Vertebrate Paleontology, 18, 10-29. https://doi.org/10.1080/02724 634.1998.10011031 
Wilson, M. V. H., Hanke, G. F., \& Märss, T. (2007). Paired fins of jawless vertebrates and their homologies across the "agnathan"-gnathostome transition. In J. S. Anderson, \& H. D. Sues (Eds.), Major transitions in vertebrate evolution (pp. 122-149). Bloomington, IN: Indiana University Press.

Wilson, M. V. H., \& Märss, T. (2012). Anatomy of the Silurian thelodont Phlebolepis elegans Pander. Estonian Journal of Earth Sciences, 61, 261276. https://doi.org/10.3176/earth.2012.4.06

Wisner, R. L., \& McMillan, C. B. (1988). A new species of hagfish, genus Eptatretus (Cyclostomata, Myxinidae), from the Pacific Ocean near Valparaiso, Chile, with new data on E. bischoffi and E. polytrema. Transactions of the San Diego Society of Natural History, 21, 227-244. https://doi.org/10.5962/bhl.part.24585

Wisner, R. L., \& McMillan, C. B. (1990). Three new species of hagfishes, genus Eptatretus (Ciclostomata, Myxinidae), from the Pacific coast of North America, with new data on E. deani and E. stoutii. Fishery Bulletin, 88, 787-804.

Wisner, R. L., \& McMillan, C. B. (1995). Review of new-world hagfishes of the genus Myxine (Agnatha, Myxinidae) with descriptions of 9 new species. Fishery Bulletin, 93, 530-550.

Woodward, A. S. (1900a). On a new ostracoderm (Euphanerops longaevus) from the Upper Devonian of Scaumenac Bay, Province of Quebec, Canada. The Annals and Magazine of Natural History, Seventh Series, 5, 416-419. https://doi.org/10.1080/00222930008678308

Woodward, A. S. (1900b). Reviews - Dr. Traquair on Silurian fishes. Report on fossil fishes collected by the geological survey of Scotland in the Silurian rocks of the south of Scotland. By Ramsay H. Traquair, M.D., LL.D., F.R.S. Trans. Roy. Soc. Edinb., vol. xxxix, pp. 827-864 pls. i-v (December, 1899). Geological Magazine, 7, 66-72. https://doi. org/10.1017/S0016756800181749

Wright, G. M., Keeley, F. W., \& De Mont, M. W. (1998). Hagfish cartilage. In J. M. Jørgensen, J. P. Lomholt, R. E. Weber, \& H. Malte (Eds.), The biology of hagfishes (pp. 160-170). London, UK: Chapman \& Hall.

Xian-guang, H., Aldridge, R. J., Siveter, D. J., Siveter, D. J., \& Xiang-hong, F. (2002). New evidence on the anatomy and phylogeny of the earliest vertebrates. Proceedings of the Royal Society of London Series B: Biological Sciences, 269, 1865-1869. https://doi.org/10.1098/ rspb.2002.2104

Xu, Q. S., Ma, F., \& Wang, Y. Q. (2005). Morphological and 12S rRNA gene comparison of two Branchiostoma species in Xiamen waters. Journal of Experimental Zoology Part B: Molecular and Developmental Evolution, 304B, 259-267. https://doi.org/10.1002/jez.b.21036

Yalden, D. W. (1985). Feeding mechanisms as evidence for cyclostome monophyly. Zoological Journal of the Linnean Society, 84, 291-300. https://doi.org/10.1111/j.1096-3642.1985.tb01802.x

Yarrell, W. (1836). A history of British fishes, Vol. II. London, UK: J.V. Voorst. Yonei-Tamura, S., Abe, G., Tanaka, Y., Anno, H., Noro, M., Ide, H., ...Tamura, K. (2008). Competent stripes for diverse positions of limbs/fins in gnathostome embryos. Evolution \& Development, 10, 737-745. https ://doi.org/10.1111/j.1525-142X.2008.00288.x

Yonei-Tamura, S., Endo, T., Yajima, H., Ohuchi, H., Ide, H., \& Tamura, K. (1999). FGF7 and FGF10 directly induce the apical ectodermal ridge in chick embryos. Developmental Biology, 211, 133-143. https://doi. org/10.1006/dbio.1999.9290

Young, G. C. (1982). Devonian sharks from south-eastern Australia and Antarctica. Palaeontology, 25, 817-843.

Young, G. C. (1986). The relationships of placoderm fishes. Zoological Journal of the Linnean Society, 88, 1-57. https://doi. org/10.1111/j.1096-3642.1986.tb00876.x

Young, G. C. (1989). The Aztec fish fauna (Devonian) of Southern Victoria Land: Evolutionary and biogeographic significance. Geological Society, London, Special Publications, 47, 43-62. https://doi.org/10.1144/GSL. SP.1989.047.01.05

Young, G. C. (1991). The first armoured agnathan vertebrates from the Devonian of Australia. In M.-M. Chang, Y.-H. Liu, \& G.-R. Zhang
(Eds.), Early vertebrates and related problems of evolutionary biology (pp. 67-85). Beijing, China: Science Press.

Young, G. C. (1997). Ordovician microvertebrate remains from the Amadeus Basin, central Australia. Journal of Vertebrate Paleontology, 17, 1-25. https://doi.org/10.1080/02724634.1997.10010948

Young, G. C. (2010). Placoderms (armored fish): Dominant vertebrates of the Devonian period. Annual Review of Earth and Planetary Sciences, 38 , 523-550. https://doi.org/10.1146/annurev-earth-040809-152507

Zajíc, J. (1995). Some consequences of recent investigations on the family Acanthodidae Huxley, 1861. Geobios, 28, 167-169. https://doi. org/10.1016/S0016-6995(95)80107-3

Zajíc, J. (1998). Acanthodians of the Bohemian limnic Stephanian. Czech Geological Survey Special Papers, 10, 1-45.

Zangerl, R. (1997). Cervifurca nasuta n. gen. et sp., an interesting member of the Iniopterygidae (Subterbranchialia, Chondrichthyes) from the Pennsylvanian of Indiana, U.S.A. Fieldiana, Geology, 35, 1-24. https:// doi.org/10.5962/bhl.title.3273

Zangerl, R., \& Case, G. R. (1973). Iniopterygia, a new order of chondrichthyan fishes from the Pennsylvanian of North America. Fieldiana Geology Memoirs, 6, 1-67. https://doi.org/10.5962/bhl.title.5158

Zhang, X. G., \& Hou, X. G. (2004). Evidence for a single median fin-fold and tail in the Lower Cambrian vertebrate, Haikouichthys ercaicunensis. Journal of Evolutionary Biology, 17, 1162-1166. https://doi. org/10.1111/j.1420-9101.2004.00741.x

Zhu, M., \& Gai, Z. (2007). Phylogenetic relationships of galeaspids (Agnatha). Frontiers of Biology in China, 2, 151-169. https://doi. org/10.1007/s11515-007-0022-6

Zhu, M., \& Schultze, H.-P. (1997). The oldest sarcopterygian fish. Lethaia, 30, 293-304. https://doi.org/10.1111/j.1502-3931.1997.tb00472.x

Zhu, M., \& Schultze, H.-P. (2001). Interrelationships of basal osteichthyans. In P. E. Ahlberg (Ed.), Major events in early vertebrate evolution: Palaeontology, phylogeny, genetics and development (pp. 289-314). London, UK: Taylor \& Francis.

Zhu, M., \& Yu, X. B. (2009). Stem sarcopterygians have primitive polybasal fin articulation. Biology Letters, 5, 372-375. https://doi.org/10.1098/ rsbl.2008.0784

Zhu, M., Yu, X. B., \& Ahlberg, P. E. (2001). A primitive sarcopterygian fish with an eyestalk. Nature, 410, 81-84. https://doi. org $/ 10.1038 / 35065078$

Zhu, M., Yu, X. B., Ahlberg, P. E., Choo, B., Lu, J., Qiao, T., ...Zhu, Y. A (2013). A Silurian placoderm with osteichthyan-like marginal jaw bones. Nature, 502, 188-193. https://doi.org/10.1038/nature12617

Zhu, M., Yu, X. B., Choo, B., Qu, Q. M., Jia, L. T., Zhao, W. J., ...Lu, J. (2012). Fossil fishes from China provide first evidence of dermal pelvic girdles in osteichthyans. PLoS ONE, 7, e35103. https://doi.org/10.1371/ journal.pone.0035103

Zhu, M., Yu, X. B., Choo, B., Wang, J. Q., \& Jia, L. T. (2012). An antiarch placoderm shows that pelvic girdles arose at the root of jawed vertebrates. Biology Letters, 8, 453-456. https://doi.org/10.1098/ rsbl.2011.1033

Zhu, M., Yu, X. B., \& Janvier, P. (1999). A primitive fossil fish sheds light on the origin of bony fishes. Nature, 397, 607-610. https://doi. org/10.1038/17594

Zhu, M., Yu, X. B., Lu, J., Qiao, T., Zhao, W. J., \& Jia, L. T. (2012). Earliest known coelacanth skull extends the range of anatomically modern coelacanths to the Early Devonian. Nature Communications, 3, 8 . https://doi.org/10.1038/ncomms1764

Zhu, M., Yu, X. B., Wang, W., Zhao, W. J., \& Jia, L. T. (2006). A primitive fish provides key characters bearing on deep osteichthyan phylogeny. Nature, 441, 77-80. https://doi.org/10.1038/nature04563

Zhu, M., Zhao, W. J., Jia, L. T., Lu, J., Qiao, T., \& Qu, Q. M. (2009). The oldest articulated osteichthyan reveals mosaic gnathostome characters. Nature, 458, 469-474. https://doi.org/10.1038/nature07855

Zidek, J. (1993). Acanthodii. In M. J. Benton (Ed.), The fossil record 2 (pp. 589-592). London, UK: Chapman \& Hall. 
Žigaitè, Ž., \& Blieck, A. (2013). Palaeobiogeography of Early Palaeozoic vertebrates. In D. A. T. Harper, \& T. Servais (Eds.), Early palaeozoic biogeography and palaeogeography (pp. 449-460). Bath, UK: Geological Society Publishing House.

Zintzen, V., Roberts, C. D., Shepherd, L., Stewart, A. L., Struthers, C. D., Anderson, M. J., ...Fernholm, B. O. (2015). Review and phylogeny of the New Zealand hagfishes (Myxiniformes: Myxinidae), with a description of three new species. Zoological Journal of the Linnean Society, 174, 363-393. https://doi.org/10.1111/zoj.12239
How to cite this article: Larouche O, Zelditch ML, Cloutier R. A critical appraisal of appendage disparity and homology in fishes. Fish Fish. 2019;20:1138-1175. https://doi.org/10.1111/ faf.12402 